Historic, Archive Document

Do not assume content reflects current scientific knowledge, policies, or practices. 



\title{
HaRdy Herbaceous and Alpine Plants
}

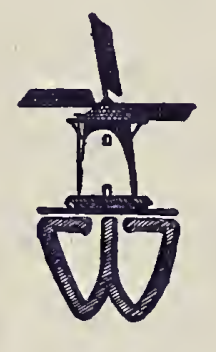

\author{
NEW SPRING CAT \\ NOT REA. ' L LL \\ BE MAlLLL IN TEBA.
}

TWENTIETH EDITION

Autumn, 1925

\section{The WAYSIDE GARDENS CO., MENTOR, $\mathrm{OHIO}$}

America's Greatest Producers of Hardy Perennials 


\section{WAYSIDE GARDENS Mentor, Ohio}

Twenty-five miles east of Cleveland, on the Cleveland-Painesville Road, at Stop 67, C. P. \& E. Electric Line

Telephone, Mentor 39-K

Telephone, Painesville 702-W.

\section{READ CAREFULLY}

All of the stock offered is grown on our own grounds, that grown from cuttings and divisions we know to be clean and true. Plants grown from seeds are from seed stocks obtained from the most reliable sources.

OUR PLANTS ARE ALL FIELD GROWN, ARE GIVEN CONSTANT CARE AND CULTIVATION AND WHEN SENT OUT ARE STRONG AND WELL DEVELOPED, MUCH LARGER AND WORTH A GREAT DEAL MORE MONEY THAN POT-GROWN PLANTS.

We do not divide our plants before shipping but send the entire plant as dug. Dividing is only done in rare cases and only then because it is necessary to get the best results.

If, after receiving, you are not satisfied with the quality of the stock, let us know and we will replace anything you mention without charge or without question.

\section{TERMS OF PAYMENT}

Customers unknown to us will please send cash or references with their order. It is impossible for us to make immediate shipment to new clients who do not send references or cheque with their order. NOT SENDING REFERENCES OR ENCLOSING CHEQUE CAUSES DELAY IN THE FORWARDING OF THE STOCK YOU ORDER.

\section{GUARANTEES}

We guarantee all stock furnished by us to be first-class, true to name, and larger than pot-grown plants, all of a size so as to give immediate results.

However, there are so many causes for failure over which we have no control that we can assume no responsibility after stock is delivered. Poor soil, unfavorable weather, ignorant or careless culture-all contribute to failure and are beyond our control.

\section{QUANTITIES ORDERED}

We do not sell less than three plants of a kind unless offered otherwise; twenty-five plants are sold at hundred rate. Five hundred at thousand rate.

\section{RISK}

All goods are at purchaser's risk after they are delivered to the forwarding companies and we receive their receipt for the shipment in good condition.

\section{SHIPPING DIRECTIONS}

Please give explicit shipping directions, stating whether stock is to be shipped by freight or express, and by what route.

Small shipments can be sent by parcel post. All such shipments will be sent insured, insurance and postage to be paid by the customer.

\section{THE WAYSIDE GARDENSCOMPANY \\ E. H. SCHULTZ President MENTOR, OHIO' J. J.GRULLEMANS Sec'y-Treas.}

Largest Growers of Hardy Plants in America 


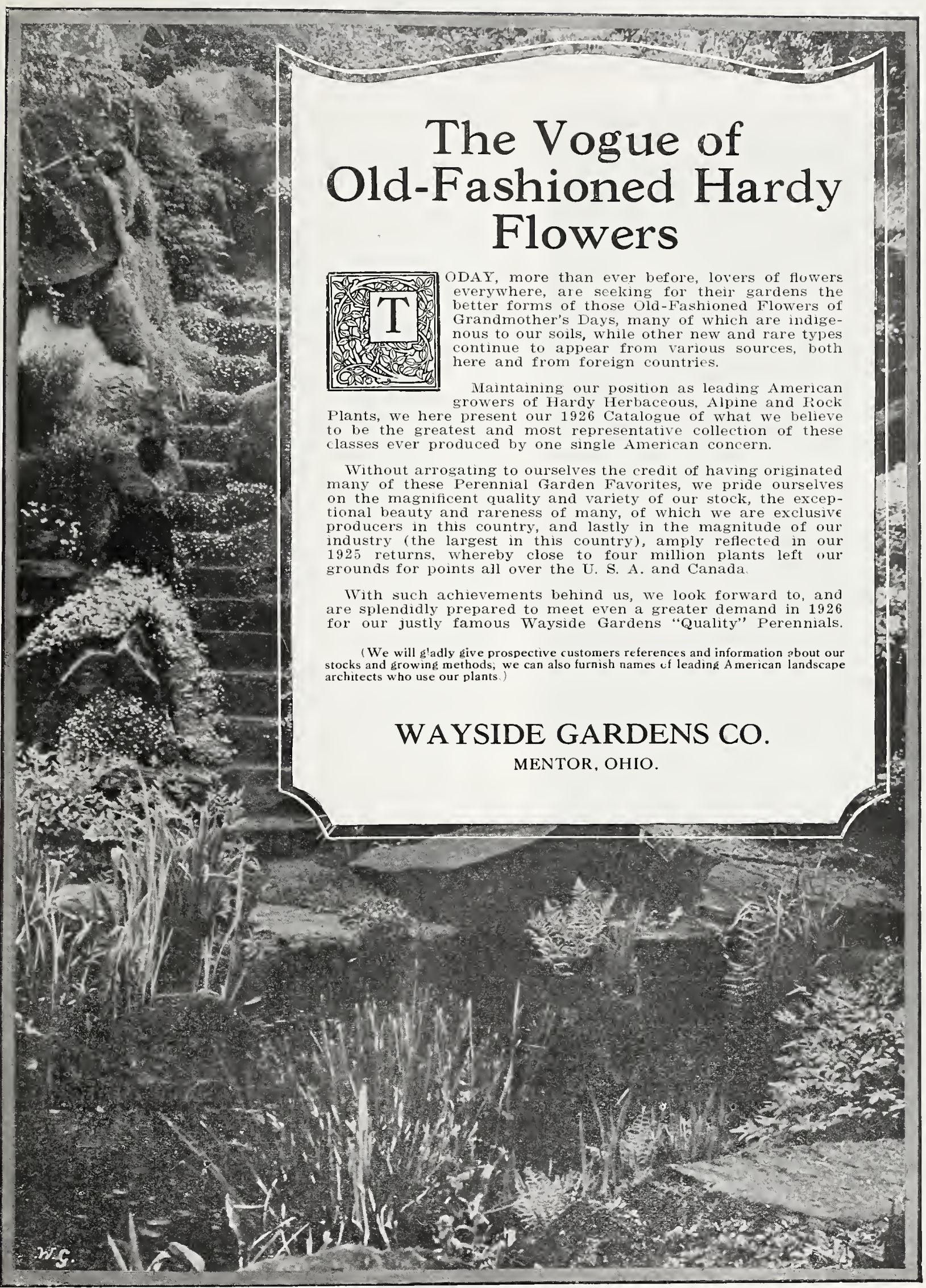




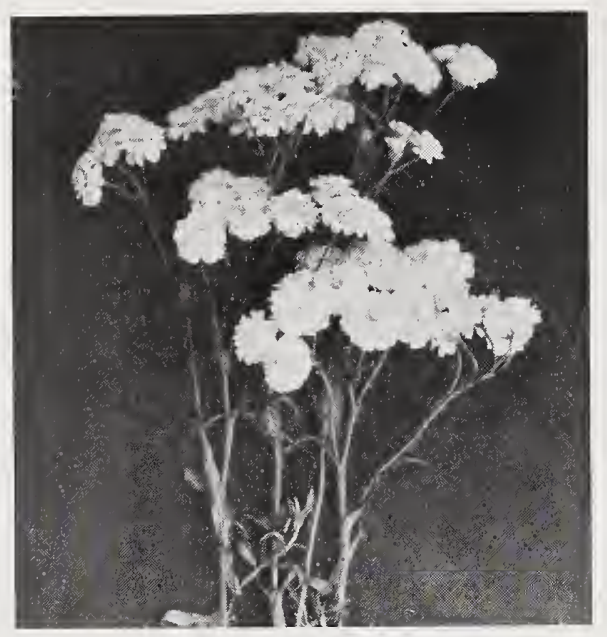

Achillea Ptarmica, "The Pearl."

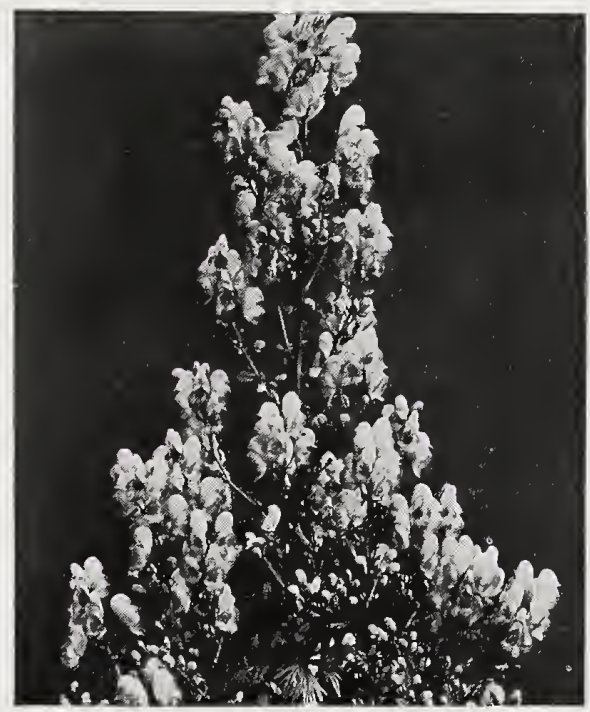

Aconitum Fischeri.

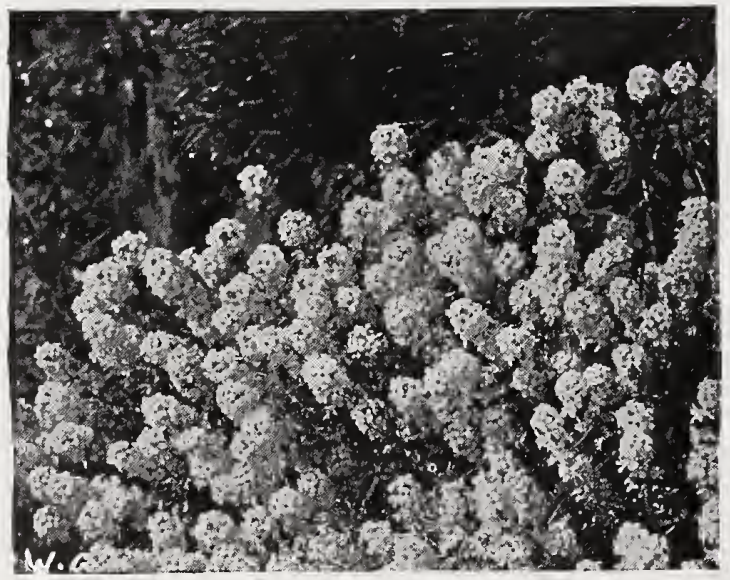

The Lovely Aethionema.
ACHILLEA (Milfoil or Yarrow).

Plants suitable for dry, sunny places. The dwarf kinds are useful for carpeting or for rockeries; the taller varietíes as border plants.

Three Doz. 100 to 4 feet (syat heads of brilliant

to 4 feet. Flat heads of brilliant

yellow flowers; finely cut foliage.
Blooms all Summer .......... $\$ 0.85 \quad \$ 250 \quad \$ 15.00$

Millefolium roseum (Rosy Milfoil). July to October. Rosy pink flow-

ers in dense heads, on stems 18 inches high. Effective on edge of shrubbery or in border ........

Perry's White. 1 to 2 feet. June to September, A choice new variety: pure white flowers over one inch across; broad, overlapping petals

Nothing better for cutting ...... double flowers all Summer. Prized for cutting ................

Ptarmica, Boule de Neige. New. An improvement on "The Pearl," with fuller and more perfect

Tomentosa. 6 to 8 inches. July to September Bright yellow flowers Excellent for rockeries ......... .85 $2.50 \quad 1500$

\section{ACONITUM (Monkshood)}

Summer- and late Autumn-flowering plants with bold spikes of hood-shaped flowers, thriving in either sun or shade. The roots are poisonous and should not be pianted where the tubers might be mistaken for vegetables. Delivery from October 15 th to March 15 th. Tubers cannot freeze.

Fischeri. A dwarf variety with Three Doz. 100 blue flowers. $18 \mathrm{in}$. September $\quad \$ 1.35 \quad \$ 4.00 \quad \$ 10.00$ Napellus (True Monkshood). 3 to 4 feet. July to August Large
dark blue flowers in a raceme ... $1.50 \quad 4.50$

Napellus alba. 2 to 4 feet. July to August. An effective plant White flowered form of Napellus ....... $1.50 \quad 4.50$

Carneum. 2 to $2 \frac{1 / 2}{2}$ feet. July to August. This variety has variegated red and white flowers:

wilsoni. 5 to 6 feet. September. A recent introduction from North China; strong, stately habit with light violet-blue flowers ....... $3.00 \quad 9.00$

ACORUS (Sweet Flag).

Calamus. 2 feet June-July. Leaves sword shape, erect; flowers inconspicuous. Root stoek pungent aromatic. Thrives best in moist soil, and may be grown in shallow water or dry land .............

ACTAEA (Baneberry).

Alba. $2 \frac{1 / 2}{2}$ feet. A very much improved form, having long spikes of clear white flowers Good for cutting; effective border plant ... 1.00 Rubra

ADONIS (Pheasant's Eye).

Amurensis (Spring Adonis). Early, yellow flowers $\ldots . \ldots 50 \mathrm{c}$ each, $1.50 \quad 5.00$

AETHEOPAPPUS (Centaurea).

Pulcherrimus $\ldots \ldots \ldots \ldots \ldots \ldots \ldots \ldots, 85 \quad 2.50 \quad 18.00$

AETHIONEMA (Persian Candytuft).

Grandiflora. Strong, twiggy bushes, covered with long, slender spikes of rosy pink flowers. One of our

Persicum. Somewhat deeper in color 


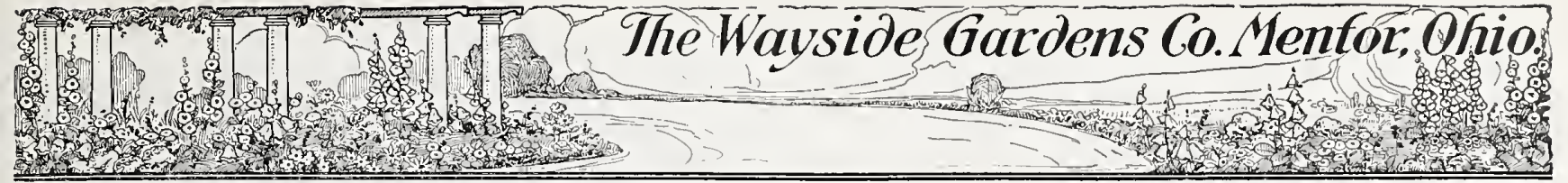

\section{AGROSTEMMA (Rose Campion).}

Stout, erect growing plants with silvery foliage, which contrasts well with the showy flowers, which are produced during June and July. Three Doz.

rosy crimson. $21 / 2$ to 3 feet $\ldots . \$ 0.85 \quad \$ 2.50 \quad \$ 15.00$

walkeri. Large heads of deep rosy

$$
\text { red flowers .................... } 85 \quad 2.50 \quad 15.00
$$

\section{AJUGA (Bugleweed).}

A useful plant for the rockery and for carpeting the ground particularly in shady positions, as under trees where grass will not grow; flowers in May and June. ${ }_{100}$

$\begin{array}{lllll}\text { Genevensis. Grows } 6 \text { to } 8 \text { inches } & & \\ \text { high; dense spikes of blue flowers. } \$ 0.85 & \$ 2.50 & \$ 18.00\end{array}$ high; dense spikes of blue flowers. $\$ 0.8$ high, with deep purplish blue flowers $\ldots \ldots \ldots \ldots \ldots \ldots \ldots \ldots . . .65 \quad 2.50 \quad 15.00$

ALYSSUM (Rock Madwort).

Very popular for beds, borders and winter flowering; of easiest culture and very free blooming. Seed may be
sown very early in the spring and up to June 15 th, also sown very early in the Spring and up
in the Fall for early Spring blooming.

Saxatile compactum. Broad masses $\quad 100$ of bright yellow flowers in early Spring. An excellent plant for the rockery or front of borders. 1 ft. $\$ 0.85 \$ 2.50 \$ 15.00$

wiersbiechi. Dense masses of canary-yellow flowers. Splendid

\section{MSONIA.}

Tabernaemontana. 2 to 3 feet. Late

May and early June. Small and numerous flowers of light blue in panicles. Smooth foliage resembling the olive. For the hardy border or planted among shrubbery.. $1.20 \quad 3.50 \quad 25.00$

\section{ANCHUSA (Alkanet).}

For producing a mass effect of brilliant blue, the Anchusas cannot be surpassed. Dropmore, the darkest one, is most effective. Opal has larger flowers and is the best of the tall varieties, producing a solid sheet of soft turquoise-blue. They should be treated as biennials, as the old plants exhaust themselves at the end of two or three years. They reproduce themselves, however, from selfsown seed The blooming season, can be extended for several weeks by cutting the spikes as soon as the flowers fade, thus preventing seeding. ers fade, thus preventing seeding.

Dropmore. Tall spikes of beautiful
blue flowers, flowering all Sumblue flowers, flowering all Sum-
mer. Rough, broad foliage. 4 to

mer. Rough, broad foliage. 4 to
5 feet $\ldots \ldots \ldots \ldots \ldots \ldots \ldots \ldots \ldots \ldots \ldots \ldots \ldots \ldots \ldots \ldots$
opal. Very beautiful variety, with myosotidifora. A distinct, dwarf perennial variety from Russia, with clusters of charming blue An effective rock plant for shady places. 1 foot .................

Pride of Dover. New. The finest (Sold out for this season).

ANTHEMIS (Marguerite).

Tinctoria. Handsome, finely cut fo-

liage, and large, golden yellow liage, and large, golden yellow flowers produced ans summer. SucMontana. Pale yellow flowers, excei-
lent for cut ting. 2 feet. June to October ..................... 1.00

ARABIS (Rock Cress).

Alpina. Pure white flowers produced in dense masses, splendid for border and rockery work, and

Alpina flore pleno. Same as above but with double white flowers:
very fine rock plant ........... 3.

AURICULA (Swiss Primrose).

Mixed Auriculas should be in every rock garden; flowers are heavily covered with a mealy substance which makes them look like butterfly wings.

Choice Mixed Hybrids

$\begin{array}{cc}\text { Doz. } & 100 \\ 3.50 & 25.00\end{array}$

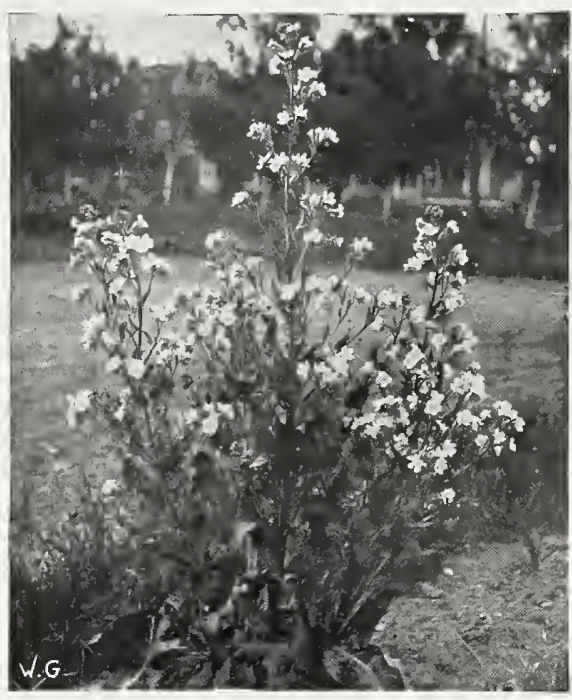

Anchusa Italica.

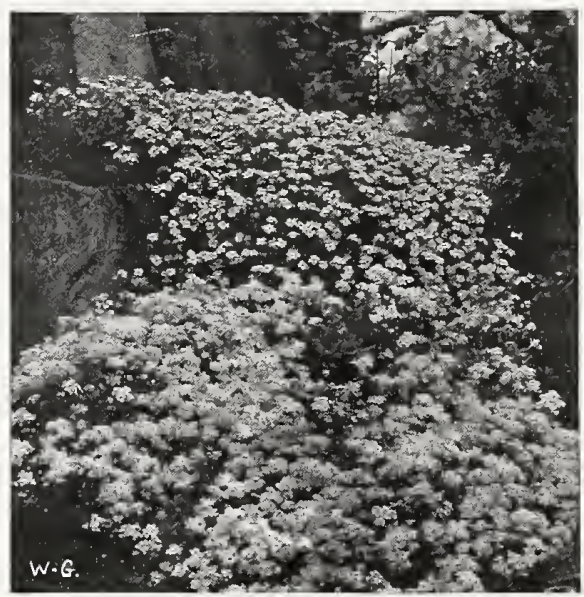

Alyssum Saxatile.

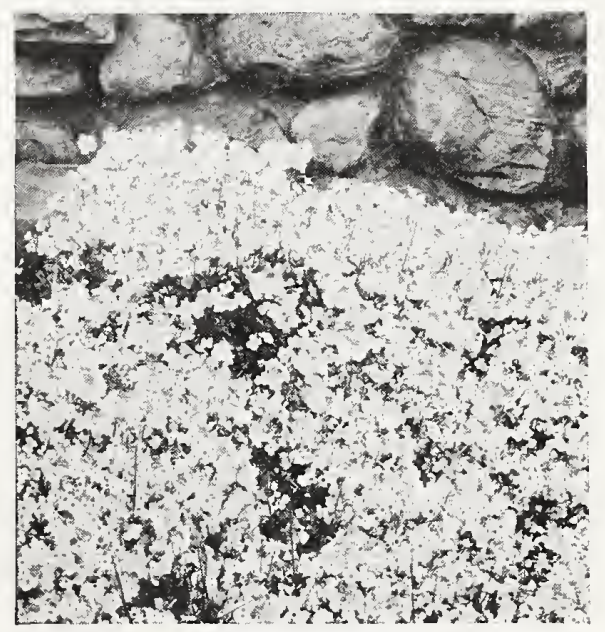

Arabis Alpina. 


\section{Derbaceous and Alpine Plants}

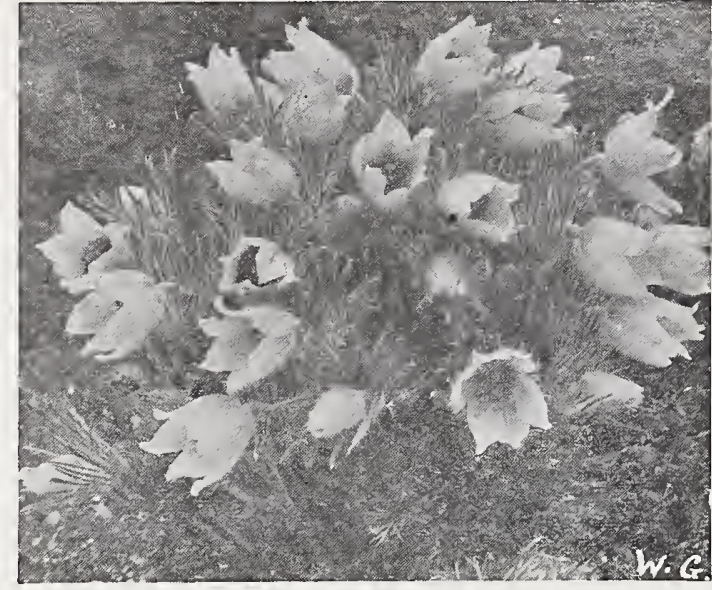

Anemone Pulsatilla.

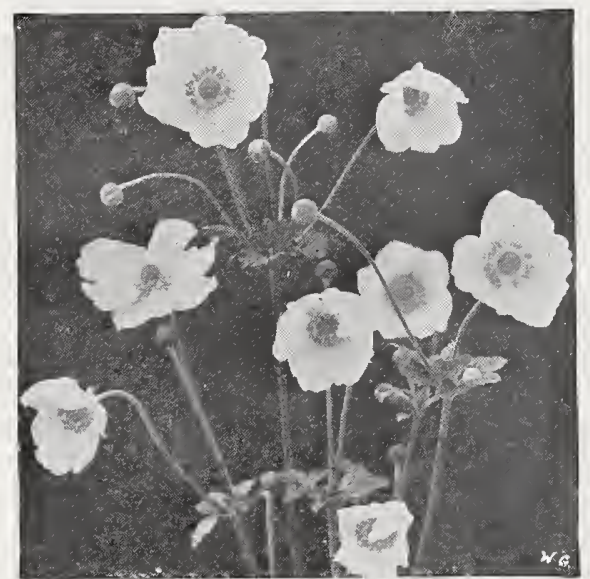

Anemone Hupehensis.

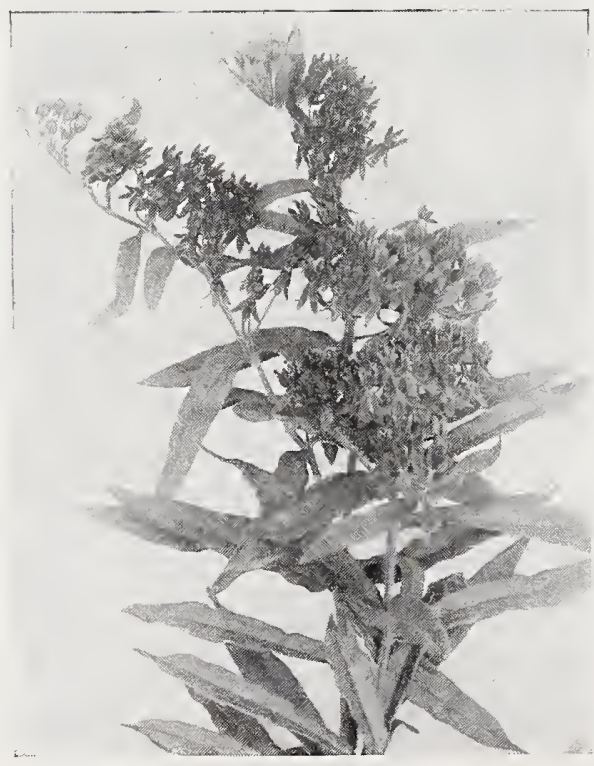

Asclepias Tuberosa.
ANEMONE (Windflower).

ANEMONE JAFONICA (Japanese Anemone).

Valuable plants suitable for massing or single specimens, They grow rapidly and are profuse in bloom, gaining strength and beauty each year. The blooming period extends from August till mid-November, the large, open extends from August till mid-November, the large, open field display. Cover plants in Winter. We offer strong, field-grown roots only.

Three Doz. 100

Alba. $\begin{gathered}\text { Purest white, with yellow } \\ \text { center } 2 \text { to } 3 \text { feet } \ldots \ldots \ldots \ldots \ldots+\$ 0.85\end{gathered}$

Alice. Large flowers of rosy car-

mine (Delivery Spring, 1926)

Kriemhilde. Double, rich pink; of

Richard Ahrends (Sold out for this

20.00

Reason)

Rubra. Beautiful rosy red; stamens

bright yellow
queen Charlotte. Abundant semi

Queen Charlotte. Abundant semi-

double flowers, broad and perfect-

to 3 feet Excellent double white

flowers. 2 to 3 feet ...........

$1.35 \quad 400$

30.00

VARIOUS ANEMONES.

Fupehensis (Early Anemone). Was originally introduced flom central China, is closely allied to Anemone japonica, which, in a miniature form, it resembles. The plant grows from 10 to 12 inches bigh and from early in August until late in Autumn; produces an abundance of flowers about 11\% inches in diameter, of a pleasing mauverose $\ldots \ldots \ldots \ldots \ldots \ldots \ldots \ldots \ldots \ldots \ldots$

Pulsatilla (Pasque Flower). Grows from 9 to 12 inches high and produces violet or purple flowers during April and May. An interesting plant for the rockery or well drained border $\ldots \ldots \ldots \ldots \ldots$. . . . with reddish purple flowers

sylvestris. Fine for cool, moist corner of rock garden or border. Large, white blossoms on nodding stems of about 12 inches Very free blooming. May and June ... 1.00

20.00 1. 00

3.00

20.00 1.00

ARENARIA (Sandwort).

Montana. A hardy perennial growing in close tufts, profusely covered with small, silvery white flowers with small, silvery white flowers season. Excellent as an edging plant in formal gardens. Suitable for rockeries in sunny places. Flowers resemble small, white, upturned morning glories …....

Mountains. Covers itself with its pure snow-white flowers One of the best of all rock plants. May.. 1.

ASCLEPIAS (Butterfly Weed).

Tuberosa. Attractive native plants, flowering during July and August, and growing about $2 \frac{1}{2}$ feet high Umbels of bright orange colored

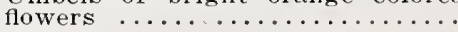

ASPERULA (Woodruff).

Odorata. 6 to 8 inches high May Habit erect; leaves usually in a whorl of eight, finely toothed. Increases rapidly and is used for carpeting shady places and for edgings. Heads of snowy white flowers. Ane

\section{ASPHODELUS (King's Spear).}

Iuteus. Tall spikes of bright yellow, lily-like flowers, very frarrant, swordlike follage, fine for 


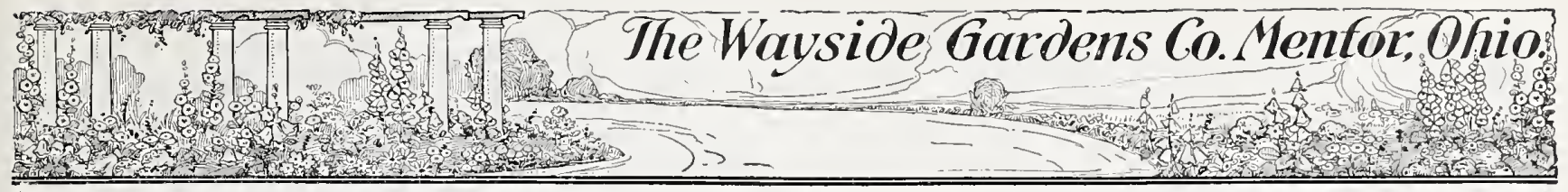

\section{AQUILEGIA (Columbine).}

As a cut flower the Long-Spurred Aquilegias are the daintiest of our outdoor grown flowers. They come in blues, whites and yellows, and shades of pink and rose in strains reasonably true practically all the various shades and colors are in the Coerulea Hybrids. They remain in bloom for a long season and are vigorous and long lived. They are not at all particular as to soil or location. although they prefer a sandy $1<x_{i} 11$ and a mojst but well drained, sunny position, and usually make themselves at home in any hardy border or rockery. Their period of flowering covers the late Spring and early Summer months. Taken as a whole, they are a most important part of the hardy garden, and should be grown in quantity by every lover of old-fashioned garden flowers.

Three Doz 100

Crimson Queen. Beautiful crimson flowers with long spurs ........ $1.00 \quad 3.00 \quad 20.00$

snow Queen. The best white, long-

spurred variety known ........... $.85 \quad 2.50 \quad 15.00$

Chrysantha. Beautiful golden yellow flowers; blooms for two months $\ldots \ldots \ldots \ldots \ldots \ldots \ldots \ldots \ldots \ldots \ldots$.

of the above .................

Canadensis (Common American Columbine). The native bright red and yellow variety, and one of the

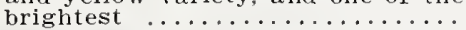

Wayside Pink. A beautiful strain of nothing but clear pink colors. We do not think that they can be surpassed

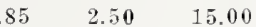

$.85 \quad 2.50 \quad 15.00$

$85 \quad 2.50 \quad 15.00$

Mrs. Scott Elliott Fybrids. There is not a better mixture grown in Elliott who has taken the highest awards at all the European exhibilons. Wond the european exh ibl long-spurred fow rom seed from this source, abso-

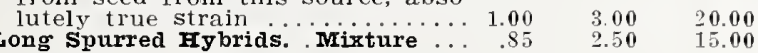

ARTEMISIA (Sage Brush).

Lactiflora. A tall growing plant of fine foliage and heads of small white flowers in August and September, which fill the garden with fragrance. A splendid and graceful cut flower $. . . \ldots \ldots \ldots .$.

ARMERIA (Sea Pink or Thrift).

Attractive dwarf plants that will succeed in any soil, forming evergreen tufts of bright green foliage, from which innumerable flowers appear in dense heads, on stiff, wiry stems. from 9 to 12 inches high. They flower more or less continuously from early spring until late in the Fall. Very useful in the rockery and border edgings.

Bee's Ruby (New). A wonderful Three Doz. 100 free-blooming variety, bearing great quantities of rosy carmine flowers. 12 to 18 inches high. (Sold out for this season).

I.aucheana rosea. Bright rose. to 6 inches $\ldots \ldots \ldots \ldots \ldots \ldots \ldots \ldots \$ 0.85 \$ 2.50 \quad \$ 15.00$

Formosa. 6 to 8 inches ......... $.85 \quad 2.50 \quad 15.00$

Robusta. 8 to 10 inches. June to October. Large, crimson flowers. Very useful for edging and cut-
ting $\ldots \ldots \ldots \ldots \ldots \ldots \ldots \ldots \ldots \ldots \ldots$

Maritima (Thrift or Cushion Pink). 3 to 6 inches. May and June. Valuable for edging: flowers fine purple; foliage grasslike, evergreen $\ldots \ldots \ldots \ldots \ldots \ldots \ldots \ldots \ldots \ldots$.

Maritima alba. 3 to 6 inches. May and June. Tufts of deep green foliage: white flowers ..........

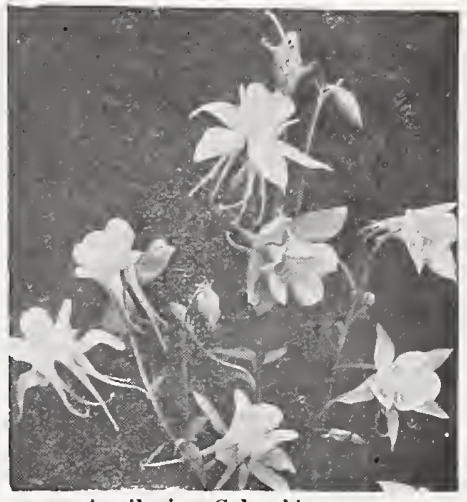

Aquilegia-Columbine.

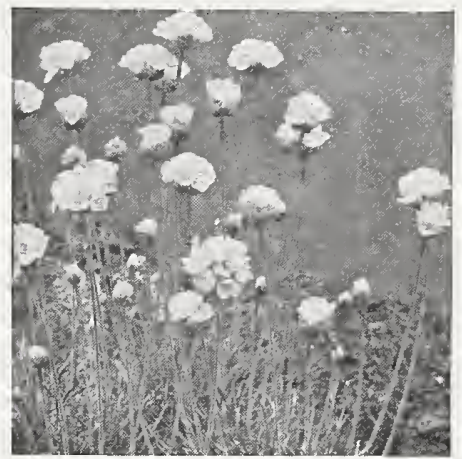

Armeria-Sea Thrift.

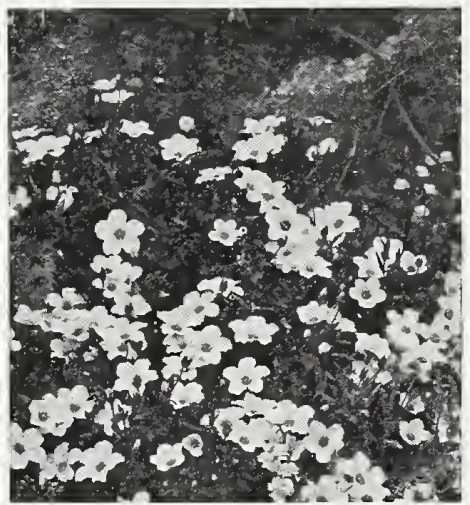

Arenaria Montana.

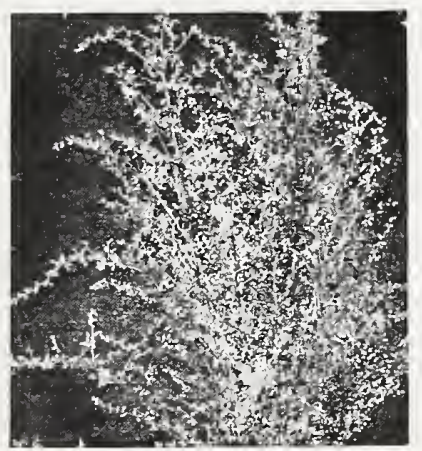

Artemisia Lactiflora. 


\section{Terbaceous and Alpine Plants}

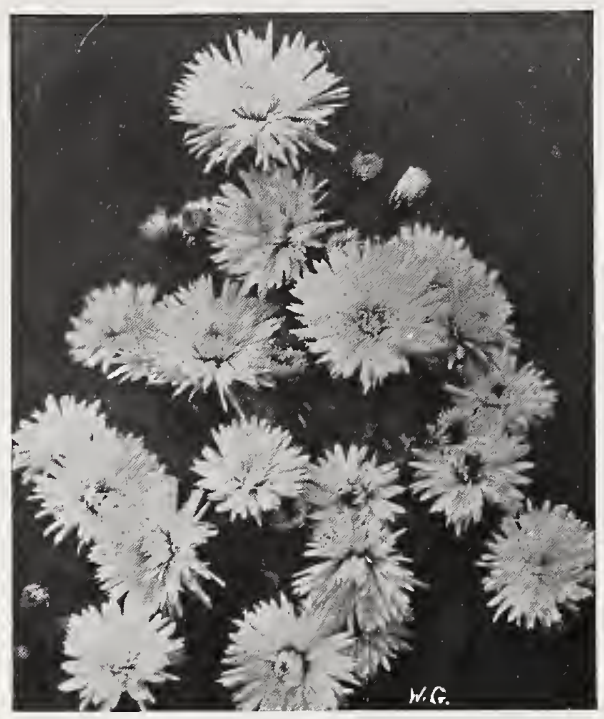

Aster, Elta.

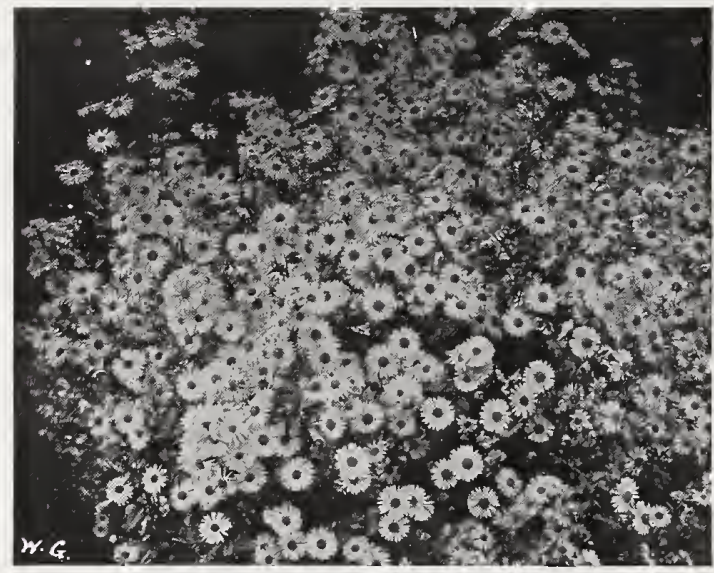

Aster, Novi-Belgi Climax.

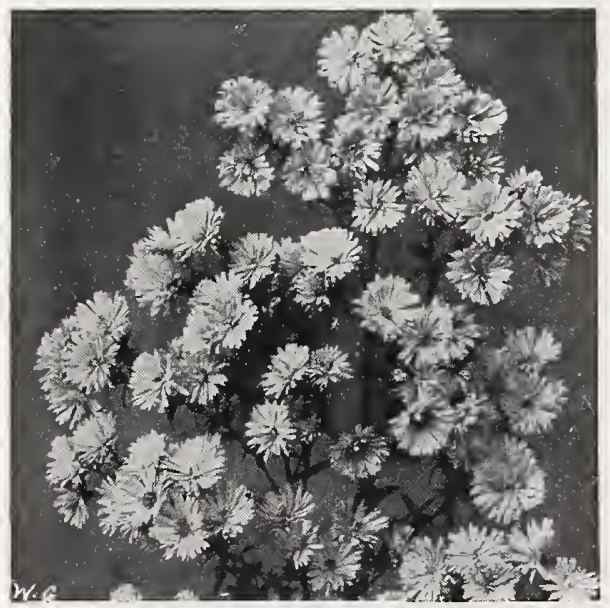

Aster, Novi-Angliae.
HARDY ASTERS (Michaelmas Daisies).

The many species, widely distinct from each other in habit and form, are. with a few exceptions, all native of North America. It is in Europe, however, that our Asters have been made by European growers, and many hybrid forms have been produced by crossing the different species.

For the best results, they require division and replanting every third year.

\section{ASTER (Michaelmas Daisy).}

Three Doz.

100

Anita Ballard. Double flowers of a $\$ 1.50 \$ 4.50 \$ 35.00$

Blue Gem. Double flowers of rich $450 \quad 35.00$

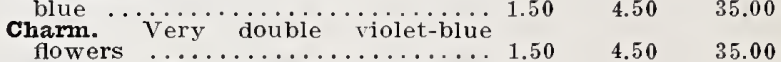

Erica. A beautiful clear pink; large

double flowers $\begin{array}{llll} & \end{array}$

Elta (New). Double flowers of pale

lilac. Very handsome shade $\ldots . .50 \quad 4.50 \quad 35.00$

Feltham Blue. A pretty aniline-blue,

Glory of Colwall. Good sized, almost double; ageratum-blue flowers ...

Grey Lady. Exquisite shade of opal, with large, semi-double flowers.

Heather Glow. Extra large flowers. freely produced, of a delightfu rose-pink shade. $41 / 2$ feet. (Sold out for this season).

Joan Vaughan. Large, semi-double flowers of deepest blue ..........

Lady Lloya. A very fine, clear rosepink. Lasts exceedingly well. 3

Mauve Queen. Very large, semidouble flowers of clear mauve, 4 fect $\ldots \ldots \ldots \ldots \ldots \ldots \ldots \ldots \ldots \ldots \ldots \ldots$

Maid of Colwall. Pure white; the finest of all whites. Long, loose
spikes of huge flowers......... Maggie Perry. Very large flowers, frequently $21 / 2$ inches across loosely arranged in large trusses, of a pleasing tone of sof mauve Most distinct and striking novelty.

Mrs. Raynor. The aeepest red of al Asters

.85

2.50

18.00

$85 \quad 2.50 \quad 18.00$

Nancy Ballard. Deep purplish-mauve flowers, semi-double in form: flower heads are branched, completely covered with masses of bloom

1.50

4.50

35.00

$50 \quad 4.50$

35.00

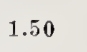

4.50

35.00

Novae-angliae roseum superbum

This is a new introduction of our

own, and is by far the best Aster we have ever seen. Color almost red and a profuse bloomer ......

Novi-belgi climax. One of the best and showiest, with large, pyramidal spikes of large, light lavender-

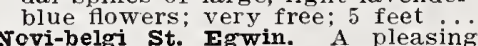
Novi-belgi St. Egwin. A pleasing
rosy pink; very free blooming; 3

Perry's white. The finest white Michaelmas Daisy yet introduced; perfect in habit and remarkably free flowering. The stout stems are well branched and covered with fowers $2 \%$ inches across

Feggy Ballard. Large, pyramidal sprays of double, rosy mauve flowers. 3 feet $(N \cdots \cdots)$ one of the finest of late introductions; large stout branching stems, covered with pale mauve blooms. Tall

Robinson v. C. A pretty bluish mauve, double flowers borne in

Robert Parker. "Pale heliotrope; 4

snowdrift. Branching, pyramidal heads of semi-double, snow-white flowers. One of the best. (Sold fowers. One of the best. (sold

Thompsoni. Large, pale blue flowers borne in huge spikes. Very
fine. (Sold out for this season). $\begin{array}{lll}1.15 & 3.50 \quad 25.00\end{array}$

$1.50-4.50 \quad 35.00$

$85-2.50-18.00$

$85 \quad 2.50 \quad 18.00$

$85 \quad 2.50 \quad 18.00$

$00 \quad 300-20.00$

$1.50 \quad 4.50 \quad 35.00$

$1.50 \quad 4.50 \quad 35.00$

$\begin{array}{lll}.50 & 4.50 \quad 35.00\end{array}$

85
$2.50-18.00$ 
NEW JAPANESE HARDY ASTER

Mauve Cushion. Distinct species which has attracted much attention by its unique habit of growth. its floriferousness and lateness in flowering. It forms a circular cushion-like plant $21 / 2$ feet across, the center of the plant rarely exceeding 9 inches in height, grad celly tapering to 3 to 4 inches at the outside: the flowers of delicate the outside; the tionve, with silvery white reflectian, measure over $1 \mathrm{x} / \mathrm{inches}$ in diameter, and are produced in such lavish profusion as to completely

their best in November $\ldots \ldots \ldots 1.00 \quad \$ 3.00 \quad \$ 20.00$ ASTER AMFIIUS.

Elegans. Long, graceful sprays of soft lavender ................. $85 \quad 2.50$ ASTER AXPINUS (Dwarf Alpine Aster).

Goliath. Indispensable for the rockery or edge of hardy borders: 6 to 10 inches high, and bears large showy, bluish purple flowers in $1.20 \quad 3.50 \quad 25.00$

Alpinus albus. Large, white flowers. $\quad .85 \quad 2.50 \quad 15.00$

Sub-coeruleus. Forms a dense tuft of leaves, from which issue many leafless stems 12 inches high bearing in June and July massive bluish violet flowers 3 inches in

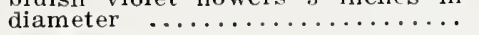

Ericoides (Big Bear). Rich violet with orange center .......... 1.20

Tataricus. Distinct, large bluish violet; very late; 6 feet ....... 85

(1)

(1)

ASTILBE (See Spirea).

AUBRIETIA (Rock Cress or False Wall Cress).

One of the daintiest and most delicately beautiful of all dwarf, creeping plants for carpeting beds or rockeries, forming brilliant sheets of blue, crimson or rose for many weeks. Massed on rockeries or in borders with white Arabis and yellow Alyssum, it forms a wharming rocks or wall, forming a cataract of color.

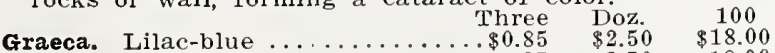

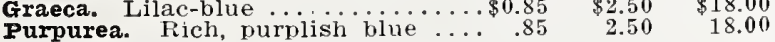

BAPTISIA (False Indigo).

Australis. Dark blue, pea-shaped flowers in June; suitable for the $\begin{array}{lllll}\text { attractive foliage. }{ }_{2} \text { feet } & \ldots \ldots & .85 & 2.50 & 15.00\end{array}$

BELLIS (Double English Daisy).

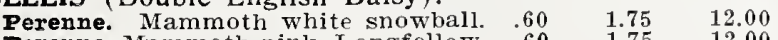
Perenne. Mammoth pink. Longfellow. $\quad .60 \quad 1.75 \quad 12.00$

BETONICA (Betony).

$\begin{array}{lllll}\text { Grandiflora. } & \text { Close tufty foliage } & & & \\ \text { with bright rose flowers } & & 85 & 2.50 & 15.00\end{array}$

BERGAMOT (See Monarda).

BELAMCANDA (See Pardanthus Chinensis).

BLEEDING HEART (See Dicentra).

BOCCONIA (Plume Poppy).

Cordata. A noble hardy perennial, beautiful in foliage and flower, and adapted for planting in the shrubbery borders, center of beds, and in bold groups in any position. It will grow in any soil or situation, attaining 6 to 8 feet in height. Flowers creamy white in terminal panicles during July and August $\ldots \ldots \ldots \ldots \ldots \ldots \ldots \ldots \ldots \ldots .85 \quad 2.50 \quad 15.00$

BOLTONIA (False Chamomile).

A showy native hardy perennial plant with large, single, Aster-like flowers; in bloom during the Summer and Autumn months, and with its thousands of flowers open at one time produces a very showy effect.

ratigquama. Pink, slightly tinged Three Doz. 100 with lavender. 4 to 6 feet $\ldots . . \$ 0.85 \quad \$ 2.50 \quad \$ 15.00$

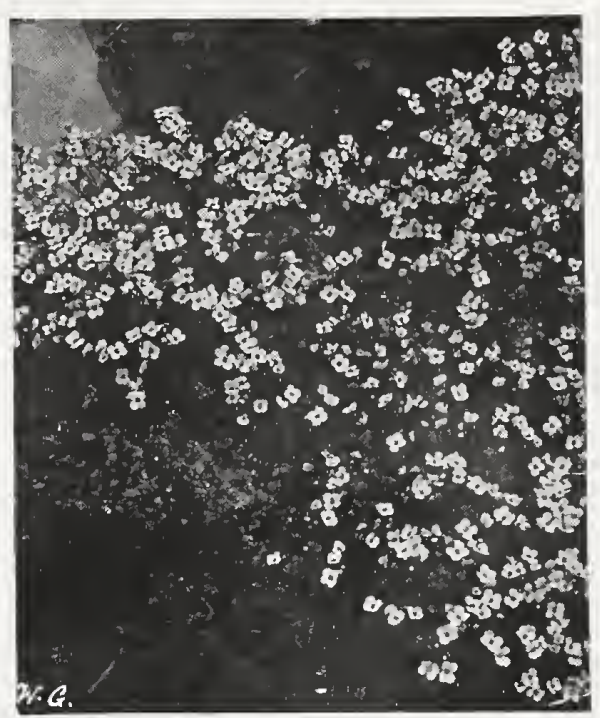

Aubrietia.

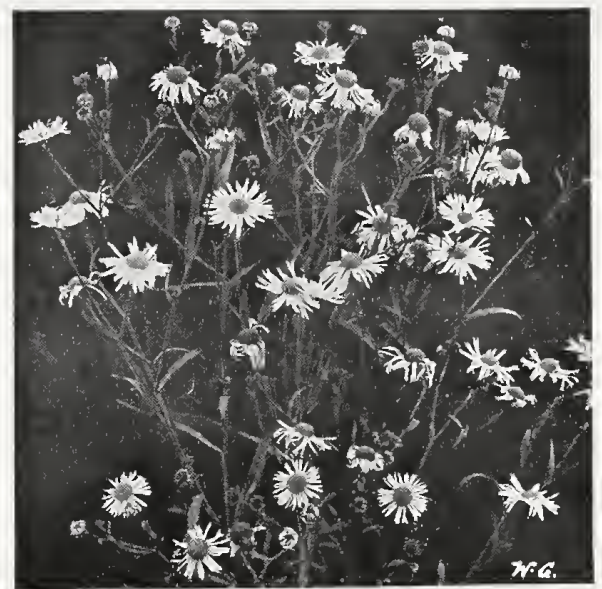

Boltonia Latisquama.

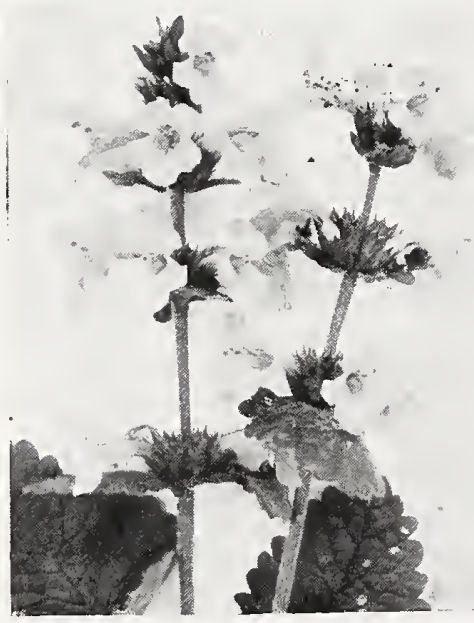

Betonica Grandiflora. 


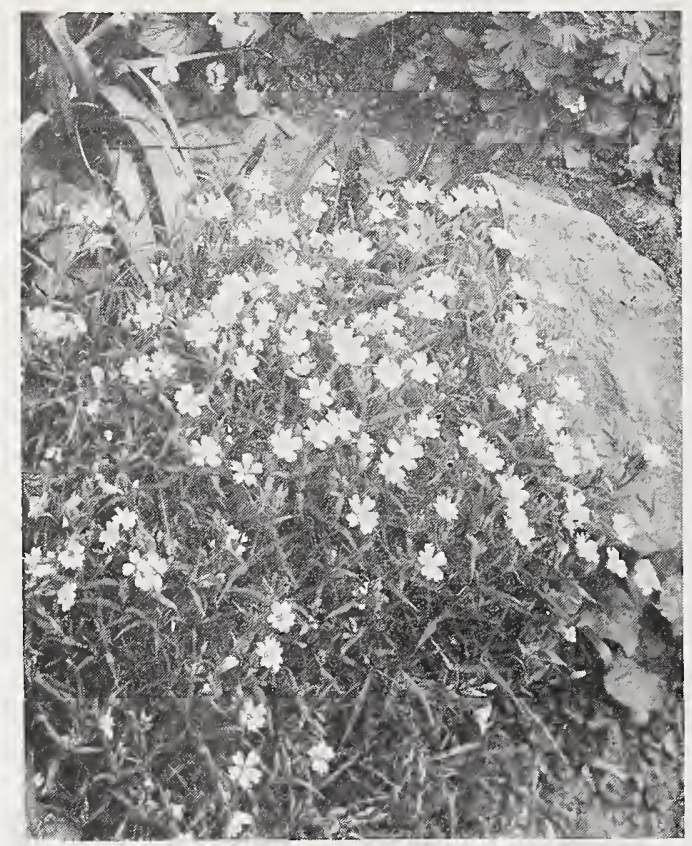

Cerastium Tomentosum.

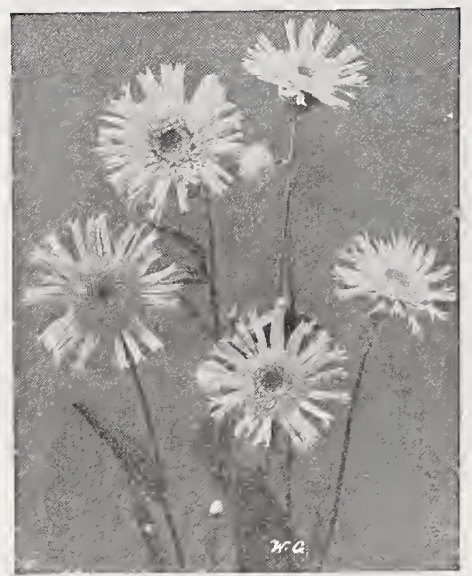

Catananche.

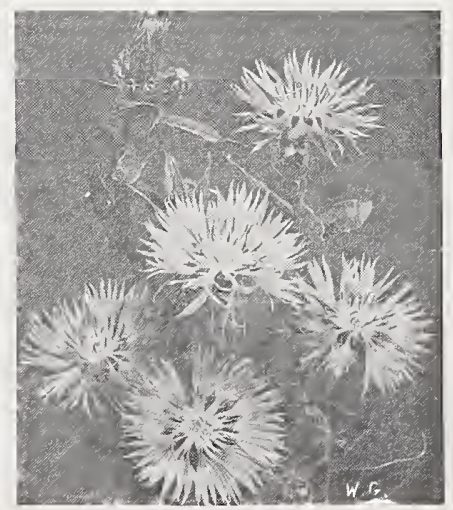

Centaurea Dealbata.
BUDDLEIA (Butterfly Bush).

variabilis magnifica. This is really a shrub, but the top usually freezes back, and new growth starts from the root like other perennials. Plants grow three to four feet and are covered with long racemes of lilac-like flowers in July, The best location is in good, rich, well drained soil in a sunny situation. It attracts the butterflies, and as many as fifty have been counted about a plant have been counted about a plant

$\$ 5.00$

$\$ 45.00$

BUPHTHALMUM (Ox-eye Daisy).

Salicifolium. Bears large, rich, golden yellow flowers through the

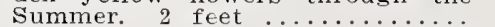

\section{CALLA.}

Elliottiana. A grand rich golden yellow variety of the Arum Lily.

(For Spring delivery only) ..
CALIRHOE (Poppy Mallow).

Involucrata. An elegant trailing plant, with finely divided foliage and large saucer-shaped flowers of bright rosy crimson, with white centers, which are produced all

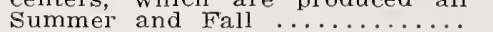

CALAMINTHA (Calamint).

Alpina. A very graceful little rock plant; growing 6 inches high, with rich purple flowers ..............

CARNATIONS (Hardy Border).

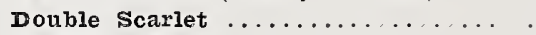

Double white ....................

Choice Mixed. Seedlings from seed
supplied by a specialist. Strong supplied by a specialist. Strong plants that will furnish an abun-
dance of flowers. We strongly recommend this grand strain for cut flowers. They keep up a most wonderful supply from June till

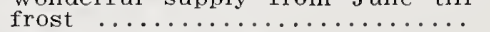

$85 \quad 2.50 \quad 18.00$

$\begin{array}{lll}1.70 & 5.00 \quad 35.00\end{array}$

$.85 \quad 2.50 \quad 1800$

CARYOPTERIS (Blue Spirea).

Mastacanthus incana. A handsome hardy perennial; grows about 3 feet high and produces rich lavender-blue flowers in great profusion der-blue flowers in great profusion A valuable plart either for bedding A valuable plart either for bedding or pot culture, blooming continu-
ously from early in september until cut by frost ............

CASSIA (Indian Senna).

Marylandica. Handsome pinnate foliage and numerous racemes of tremely desirable plant of the easiest culture ..............

CATANANCHE (Cupid's Dart).

Caerulea. 2 feet. July and August Heads of pretty deep blue flowers on long stems. Profuse and excellent cut flower ..................

CENTRANTHUS (See Valeriana).

CENTAUREA (Hardheads or Knapweed).

Makes a fine display in the border; also excellent for cutting. Three Doz 100

Babylonica. Showy yellow flowers, suitable for planting in shrubbery

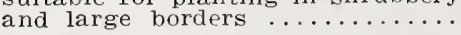

Dealbata. Large and striking rosepink flowers. June-July. 2 feet ..

golden yellow flowers; useful for cutting and showy in borders. July and August. $31 / 2$ feet .........

Montana (Perennial Corn Flower). Grows 2 feet high, bearing large violet-blue flowers from July to september..$\ldots \ldots \ldots \ldots \ldots \ldots \ldots$

Montana alba ..................... Ruthenica. Very tall plant with July-September. 5 feet ........ $\$ 0.85 \$ 2.50 \$ 15.00$ $\begin{array}{lll}.85 & 2.50 \quad 15.00\end{array}$ 
CALYSTEGIA (See Vines).

Three Doz.

100

CEPHALARIA (Roundhead).

Tatarica. 6 feet. July and August.

Flat heads of showy cream-white
flowers. Suited for rear of bor-

ders, where effects are desired $\ldots \$ 1.00 \quad \$ 3.00 \quad \$ 20.00$

CERATOSTIGMA (See Plumbago Larpentae).

CERASTIUM (Snow-in-Summer).

Tomentosum. A low-growing plant having. silvery white foliage and producing an abundance of snowfor rock or border purposes...

CAMPANULA (Bellflower).

Indispensable hardy garden flowers, of much variety of form, some being of tall and imposing habit, while others are dwarf, compact little plants, suitable for edging, rockwork, etc. They like a good, rich soil, and last much longer in bloom if planted in a half-shady place. All of the taller growing kinds should be staked to prevent injury from high winds.

Alliariaefolia. A grand border plant with tall spikes of long, pendent

Three Doz $\quad 100$

bells. 3 feet $\ldots \ldots \ldots \ldots \ldots \ldots \ldots$
Bononiensis. borne profusely on slender stems.

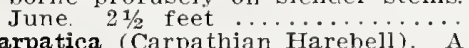

pretty species growing in compact tufts, not exceeding 8 inches ligh flowers clear blue held erect on wiry stems. It begins blooming in June, continuing until October. As an edging for a hardy border or for the rockery it is unsurpassed the rockery it is unsur-

Carpatica alba. A pure white form of the preceding ..............

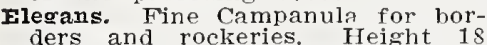
ders and rockeries. Height 18

Glomerata. A favorite old-fashioned herbaceous plant producing deep blue flowers in large, close heads. Height 18 inches

Grandis (Great Bellflower). 11/2 feet. May and June. Very showy, large. saucer-shaped flowers, rich violetblue

Grandis alba. A white form of the above ..............................

Latifolia macrantha. feet. June mous drooning bells of fine satiny lilac and deep purplish shades..

Iactiflnra coerulea. Pale blve flowers during July and August. 21/2 feet

Persicifolia grandiflora (White). One of the finest Camnanulas. with large, handsome white. bollshaped flowers. A great acquisition. Height 2 feet .............. Persicifolia grandifora alha flore
pleno. Double-flowered form of the above .................... excellent companion to the white variety, the large bright blue flowers making an effective contrast. Height 2 feet ...........

Persicifolia grandiflora coerulea flore nleno. Double-flowered form of the above

Pyramidalis. Mixed colors. An elegant pot plant. Height 4 feet.
Raddeana. Violet-blue. bell-shaped

Radoana. Violet-blue. bell-shaped inches

$1.00 \$ 3.00$

$\$ 20.00$

$.00 \quad 3.00$

20.00

Rotunaifolia (Blue Bells of Scotland or Harebells). 1 foot. June to August. In the wiln it is more slender and taller than in the garslender and taller than in the gar-
den: rlear blue flowers. Especially den: rlear blue flowers. Especially garden. or steen slones, if planted to show pendent habit ..........

Trachelium (Coventry Bells) 2 to feet. July and August. Sturd somewhat drooping flowers ....

.85

.85

.85

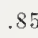

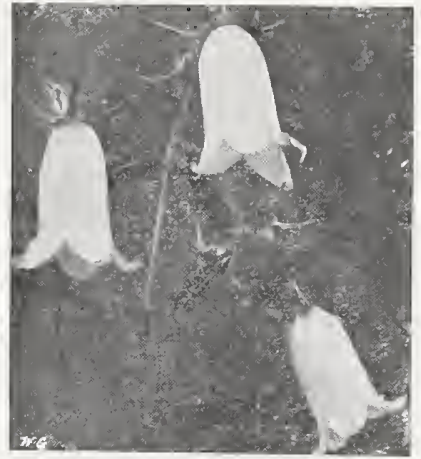

Campanula Rotundifolia.

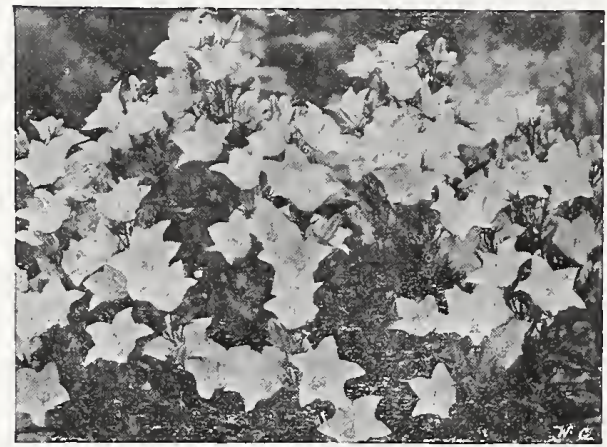

Campanula Carpatica.

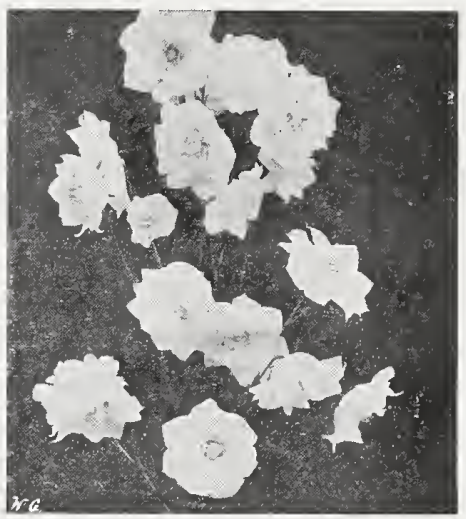

Campanula, Double Persicifolia.

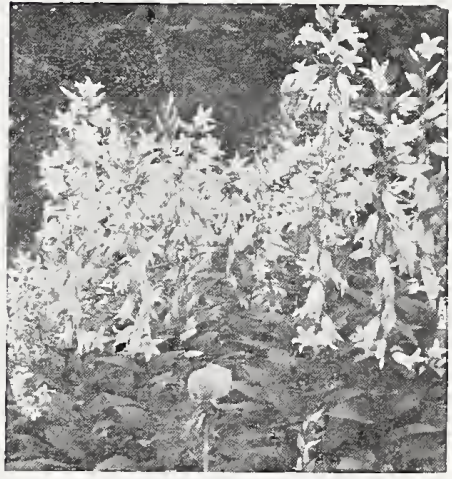

Campanu'a Latifolia. 


\section{Merbaceous and Alpine Plants}

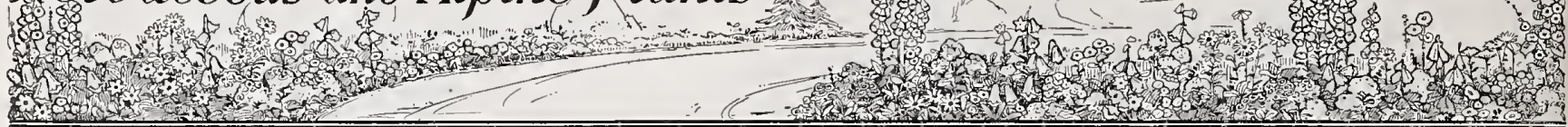
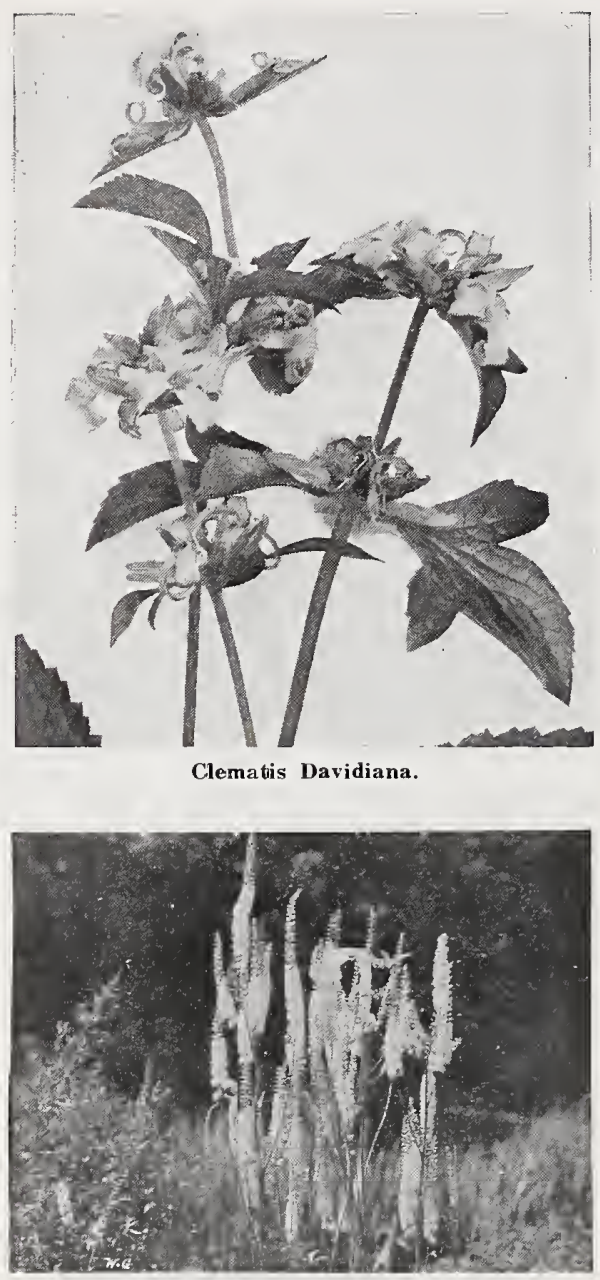

Cimicifuga-Snakeroot.

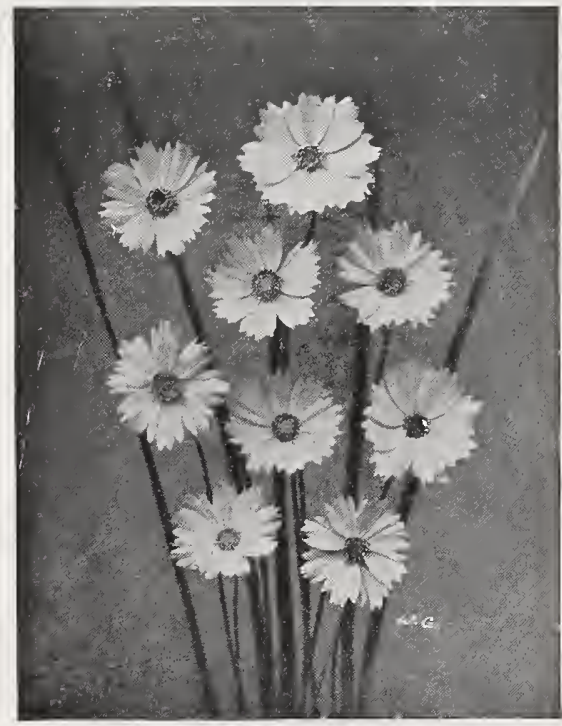

Coreopsis Grandiflora.

CAMPANULA MEDIUM (Canterbury Bells).

These imposing herbaceous hardy biennials are profusely covered with large, bell-shaped flowers; extremely showy in shrubberies and mixed borders. Height 3 feet. Plants potted in October make most beautiful plants for the conservatory and greenhouse in the spring, coming into flower, without being forced in any way, about two Three Doz 100 months before those in open ground.

Calycanthema (Cup and Saucer).
Large, semi-double flowers, each

Large, semi-double flowers,

Pink. Beautiful variety; charming pink flowers ............. $\$ 0.5$ flowers are white $\ldots \ldots \ldots \ldots \ldots$...........

Medium (Single Canterbury Bells).

Pink. Beautiful rich shade .....

Blue. Light flowers fow . . . . .

Medium flore pleno (Double Canterkury Bells).

Blue $\ldots \ldots \ldots \ldots \ldots \ldots \ldots \ldots \ldots \ldots$

Fink. Delicate color harmonizing

CHELONE (Shellflower).

Handsome perennials, growing about two feet high, and bearing numerous spilses of large flower heads, Summer and Fall.

Three Doz. 100 creamy white flowers .........\$0.85 $\$ 2.50 \quad \$ 15.00$ Lyoni. Heads of showy purplish
red flowers ..................

CHEIRANTHUS (Siberian Wallflower).

Allioni. A beautiful rock plant Dazzling fiery orange flowers, on stems about a foot high. Best
used as a biennial as it frequently blooms itself to death ..........

CIMICIFUGA (Snakeroot).

Racemosa. Handsome species bearing in July and August spikes of pure white flowers; well suited for planting at the back of border, or for naturalizing at the edge of the woods. 4 to 6 feet .........

COREOPSIS (Tickseed).

Grandiflora. An improved variety with large, bright yellow flowers; one of the best hardy plants. Fine for cut flowers all summer long.

$\$ 1.50 \$ 10.00$

$1.50 \quad 10.00$

$1.50-10.00$

$1.50 \quad 10.00$

$1.50 \quad 10.00$

$1.50 \quad 10.00$

$1.50-10.00$ RUCIANELLA (Crosswort).

stylosa. Early flowering hardy perennial, suitable for rock work bright purple, ball-shaped flowers. Height 6 inches. Unique.

CONVALLARIA (Lily-of-the-Valley). Majalis. This popular and fragrant subject repays for being well treated. Grand for massing nea shrubs or along shaded borders. Native Pips ............. .50 Native Clumps (in Fali only) … 1.35 Imported Pips (Berlin strain) $\ldots . .85$

CORONILLA (Crown Vetch).

varia. A strong creeper; good for covering rough banks; showy heads of pink and white, peashaped flowers. 1 to 2 feet. June-

August ....................

Davidiana. A most desirable variety, with fresh, bright green foriety, with fresh, bright green foflowers of deep lavender-blue during August and September: deliciously fragrant; $2 \frac{1}{2}$ feet ...

Integrifolia coerulea. A good border plant, growing from 18 to 24 inches high, producing its small but interesting porcelain-blue flowers from June to August 2 . and produces fragrant, pure white flowers in very large, showy clusters during $J$ une and July .... 2.35 7.00

3.00

20.00 


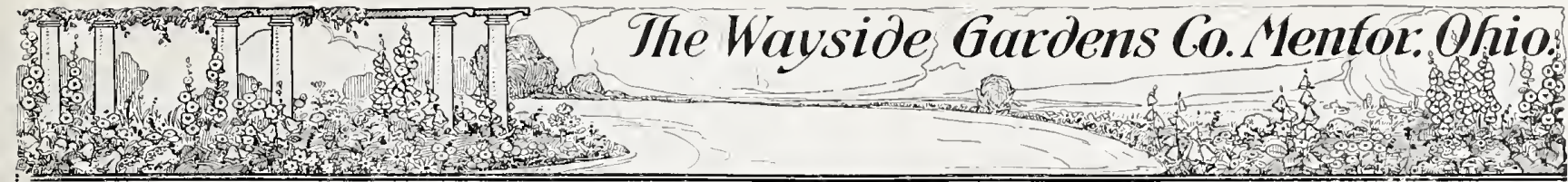

\section{CHRYSANTHEMUMS}

Hardy Chrysanthemums are undoubtedly one of the best of border plauts, coming in with a grand display of color and cut flowers when other plants are on the wane. In our estimation one cannot plant too many. From sepa seemingly inexhaustible supply.

\section{HARDY OTD-FASHIONED VARIETIES}

Full Field-Grown Clumps-Not Divisions.

We collected from old gardens some of the old-fashioned Chrysanthemums which are really hardy and which bloom in October and November, after all other outdoor flowers are gone. Often in bloom when the snow is on the ground; are very showy. 3 to 4 feet high. When in bloom are a perfect mass of flowers.

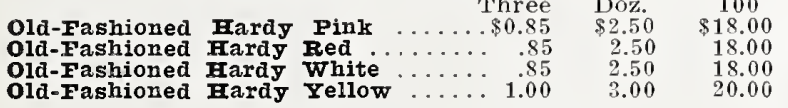

\section{CHOICE NAMED VARIETIES}

The varieties offered below comprise the choicest new hardy outdoor sorts, that need but a light covering to carry them through the Winter. We have chosen the earliest to bloom, so that the full enjoyment of these best-of-all Autumn flowers may be derived by those in northern territories where winter comes early.

Fest results are obtained from pot-grown plants.

Supplied from $23 / 4$-inch pots in Spring only.

\section{RARIY-FIOWERING VARIFTIES}

(In full bloom from September 15 th on).

Carmelite (Glory of Seven Oaks). Three Doz.

Golden yellow $\ldots 2.50$

Provence. Rose-pink, tipped rosy

red ....................... 85

Firelight. Scarlet and carmine ... .85

Carrie. Rich yellow blooms ..... .85

Idolph. A pleasing salmon-pink ... .8

Mrs. H. Craig. Yellow, overlaid

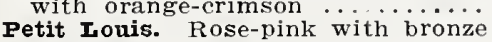

center $\ldots \ldots \ldots \ldots \ldots \ldots \ldots \ldots \ldots$. . . . . . . .

Brune Poitevine. Deep velvety-red.
Argenteuillais. Scarlet, tipped yel-

low

skibo. Yellow with reddish center.

$85 \quad 2.50$

$85 \quad 2.50$

IATE SUMMER AND EARIY AUTUMN VARIETIES (In full bloom from October 1st onward)

Nellie Blake. Reddish-copper ..... $.85 \quad 2.50$

Tints of Gold. Large, beautiful

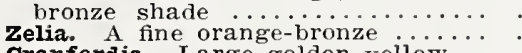

Cranfordia. Large golden yellow . .

Mrs. Fr. Harrison. Medium sized

Mrs. \#. Harrison. Medium sized

october Gold. Rich golden bronze.

Edna. Creamy white

Adironda. A fine bronze

oconto. Splendid pure white ......

Mrs. Phillips. Beautiful single pink.

Mahogany. Reddish bronze ...... .85

Harvest Home. Fine golden yellow. .85

.85
.85
.85
.85
.85
.85
.85
.85
.85
.85
.85

\section{MDSEASON VARIETIES}

(In full bloom from October 15 th onward). Red Button. Reddish bronze button; hardy and free flowering ...

Firefiy. Bright red; very showy

Ruth. Claret-red

Mitzi. Yellow, with reddish center.

Mrs. F. H. Bergen. Bright pink . .

White Dotty. Splendid white .....

snowarop. Pure white button;

Tellie zléris. Incurved clear pink.

Comoleta. Medium sized pure yellow.

Rose Travena. Very large deep roseRose Travena. Very large deep rosecapt. R. H. Cook. Dark rose with brownish center $\ldots \ldots \ldots \ldots \ldots \ldots$ Boston. Beautiful bronzy orange. Tall and branched

Indian. Copperish red

Indian. Copperish red
$.85 \quad 2.50$

$.85 \quad 2.50$

$85 \quad 2.50$

$.85 \quad 2.50$

$85-2.50$

$.85 \quad 2.50$

$85 \quad 2.50$

$.85 \quad 2.50$

$.85 \quad 2.50$

$85 \quad 2.50$

.85

.85

.85

.85

.85
.85

2.50
2.50

2.50

2.50

2.50

2.50
2.50

2.50

2.50
$\$ 15.00$

15.00

15.00

15.00

15.00

15.00

15.00

15.00

15.00

$50 \quad 15.00$

$\begin{array}{ll}.50 & 15.00\end{array}$

15.00

2.50

2.50
2.50

2.50
2.50

2.50
2.50

.50

.50

15.00

15.00

15.00
15.00

15.00

15.00

15.00

15.00

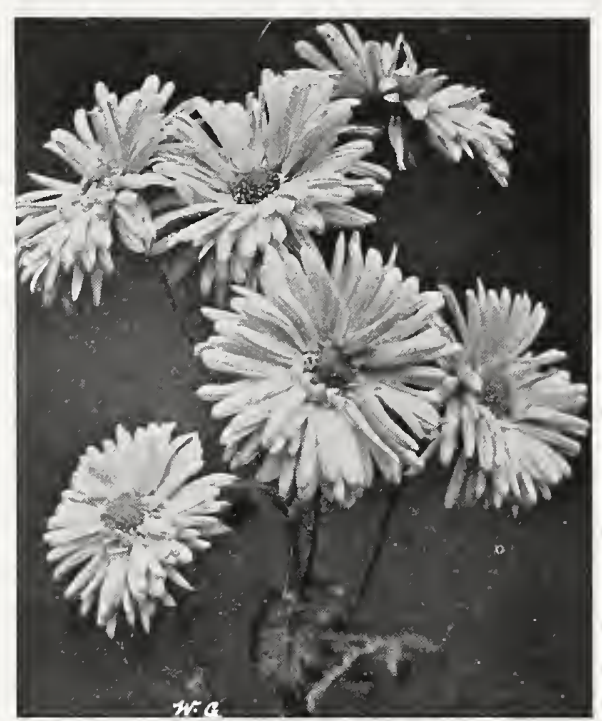

Hardy Chrysanthemums.

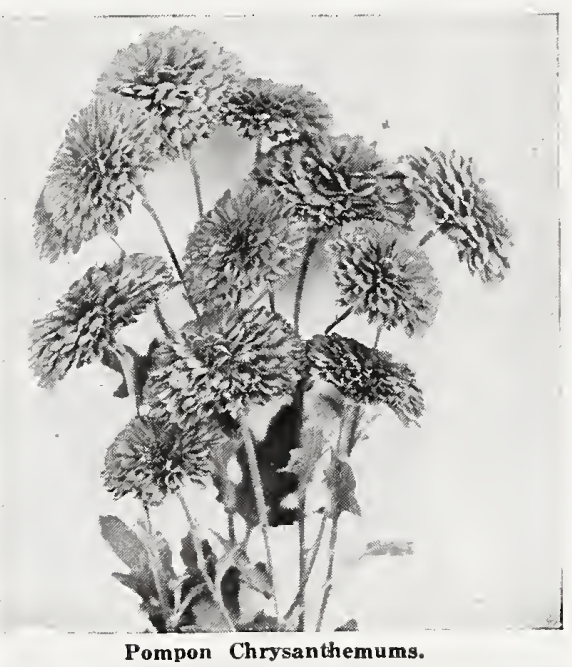

15.00

15.00

15.00

15.00

15.00
15.00

15.00

15.00

15.00

15.00

15.00

15.00

$\begin{array}{ll}2.50 & 15.00\end{array}$

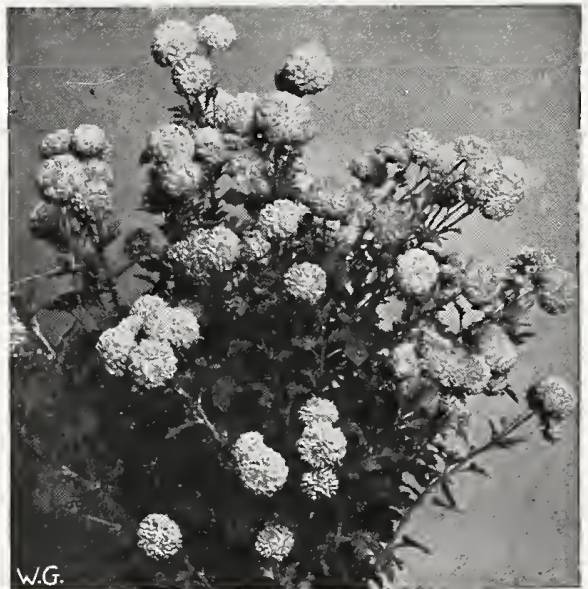

Button Chrysanthemums. 


\section{Terbaceous and Alpine Plants}

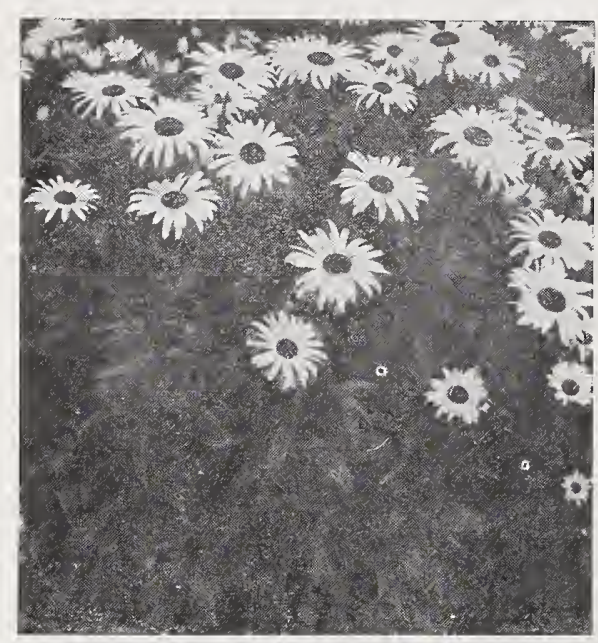

Shasta Daisy, Mrs. C. Lowthian Bell.

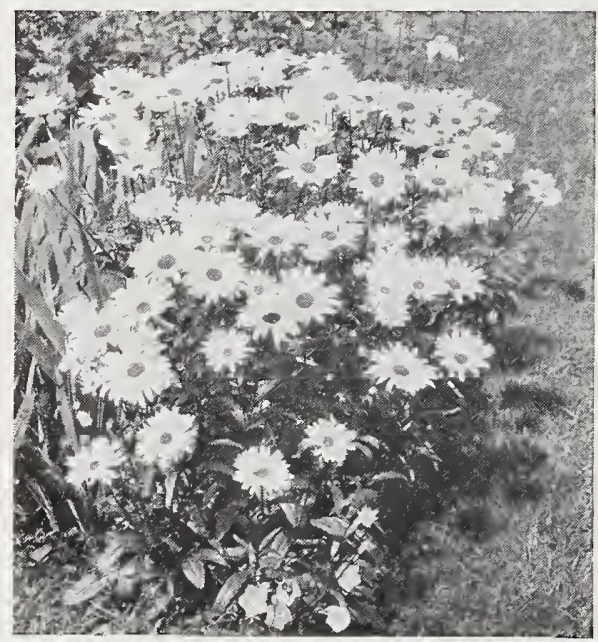

Daisy, Glory of Wayside.

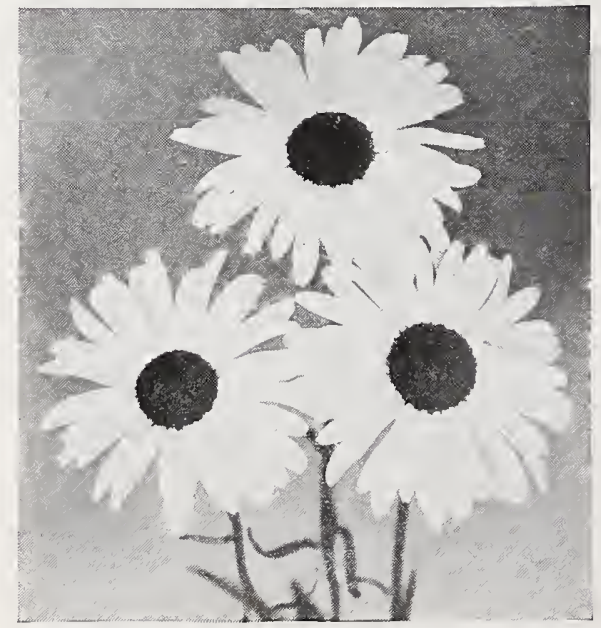

Daisy, Etoile d'Or.
CHRYSANTHEMUM MAXIMUM (Shasta Daisy).

The improved varieties of Marguerite, all allied to the Shasta Daisy that adorns our fields in the Spring, are among the most useful of our garden flowers. Not only have these flowers been greatly improved in size and form, but there are now early and late blooming varieties which give a succession of long-stemmed flowers so valuable for vase decoration during four months of the year Glory of Wayside is a variety worthy of attention, and Etoile d'Or is robust and free-flowering. Mrs. C. Lowthian Bell has enornous flowers with strong stems. The Shasta Daisy has a yellow center with long, while petals, the slender stems springing from the base of the plant, and is most attractive either in the perennial border or as a cut flower. Common kinds like Alaska have been discontinued.

\section{FOR MAY FIOWERING}

Three Doz

100

Ieucanthemum flore pleno (Double White Shasta Daisy). Flower double pure white of medium size, produces from 30 to 50 flowers; produces from 30 to 50 flowers; perfectly hardy without any protection. Our lastest and best addi-
tion to the Shasta Daisies .... $\$ 0.85 \quad \$ 2.50 \quad \$ 15.00$

Glory of wayside. Abundant flow-

ers and blooms early in May; ex- $85 \quad 250 \quad 15.00$ FOR JUIY FLOWERING, ONWARD

Sutton's Perfection. Beautiful flow

ers, having long, pure white petals

with small, yellow centers. A great

favorite. Ileight $21 / 2$ feet .....

$1.20 \quad 3.50 \quad 25.00$

Mrs. C. Lowthian Bell. This mag nificent white Marguerite is undoubtedly the largest floweled variety of this class. Flowers frequently measure six inches across. with very broad petals of great substance. Height $2 \frac{1}{2}$ to 3 feet.. $1.20 \quad 3.50 \quad 25.00$ FOR SUIMTER AND IATE FIOWERING

Etoile d'Or. Another of the largeflowered English type, producing the largest and best flowers of any

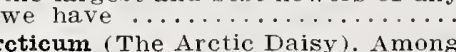

Arcticum (The Arctic Daisy ) Among fall-flowering perennials this is a
perfect gem. It forms an attractive rosette-like clump of pretty dark green foliage, and in september multitudes of flower stems appear, terminated by pure white flowers 2 to $21 / 2$ inches in diameter. These begin to develop during the last week in September, and continue in good condition throughout october, and frequently into Novetober, and frequently into No-

Uliginosum (syn. Pyrethrum). Giant Daisy. Grows 3 to 4 feet high, covered with large, white, daisylike flowers from June to September flowers from June to sep-

CYPRIPEDIUM (Lady's Slipper)

Hardy orchids that thrive in a moist peaty soil, in shade or partial shade; flowers are very interesting with their odd shapes and uncommon colors and markings.

Acaule (Lady's Slipper; Moccasin Three Doz. 100 Flo Red Lady slipper, but the flower is rose-purple in color ..............

Pubescens (Large Yellow Lady's florum, only the flowers are laror. This should be planted in a rich bed in which leaf-mold should be a part, in some moist, yet well drained shady spot ....................

Spectabile (Showy Lady's Slipper). The finest and most showy of all our orchids. It grows about two feet high, bearing along the stalk several rather large, roundish leaves, and on top one or two quite large, rose-purpie or nearly $1.20 \quad 3.50 \quad 25.00$

DAPHNE (See Shrubs, page 50).

Price .................4.50 15.00 


\section{DELPHINIUM (Larkspur).}

English Delphiniums are the most beautiful hardy plants in cultivation, for they have such an immense variety of beauty and increase in size, in beauty, and often in quantity, year after year. Some varieties grow 8 feet high in rich soil. They have immense spikes of and their season is long; in fact, they will bloom from Spring till Fall.

The culture of Delphiniums is exceedingly simple. They thrive in almost any position, and may be planted at any time of the year, provided that in summer the plants are not too forward, and that they be well watered if the weather is dry. The soil may be a rich, friable loam, which suits them finely; but any soil, even hot and sandy, if well watered and manured, will give excellent results.
Placed in lines, as a background to a border, or in groups of, say, three plants at intervals, the effect of the Delphinium is exceedingly fine. A succession of flowers may be expected from Spring to early Autumn, especially if the spikes, which have done flowering early, be cut down to the ground; fresh growth will then be produced which will give blossoms. Watering in Summer will increase size of spike and flower. Top-dressing is greatly recommended on certain soils, instead of the bare surface of the ground being left exposed to the sun. Some of the neater dwari Alpine and other hardy plants may be utilized to plant between and around oelphiniums. coal ashes strewn the Winter and Spring. Any garden soil suits the Delphiniums.

Choicest Wayside Garden Un-named Hybrids here offered are the newest, the best and the finest to be secured anywhere. The range of colors varies from the palest shade of blue to the deepest indigo-blue and royal-purple with many intermediary pastel tones of mauve, pink and lavender blendings. pink these new hybrids are flowAmong these new hybrids are fiowers of huge size in both single and double forms. This strain has been raised from seed saved from the finest named kinds in creation. Visitors at our nursery proclaim them the best they have ever seen. Those who wish to perfect their already much prized

the cannot afrord to over $\$ 1.50 \$ 450-\$ 35.00$

Imported Strain (Blackmore and Langdon's) Grown from seed of famous named sorts. Introduced by England's foremost grower of Delphiniums.

1-year-old plants $\ldots \ldots \ldots \ldots \ldots \ldots$
2-year-old plants $\ldots \ldots \ldots \ldots \ldots$
1.00

Belladonna. They are our best blue cut flower, are perfectly hardy and established plants produce a number of spikes, giving three crops during the season. They are in demand by every florist for decorating, the light blue Belladonna combining especially well with other flowers. The two- and three-year-old plants of Belladonna can be forced in the greenhouse to great advantage.

house to great advantage 1-year. Light sky-blue $\begin{gathered}\text { 1.jear. } \\ \text { 2ight }\end{gathered}$ for forcing $\ldots \ldots$-year. Light sky-blue... Select for forcing..$\ldots \ldots \ldots \ldots \ldots \ldots$

Bellamosa. A dark blue of the type of Belladonna with the color
of the old Formosum variety, but not liable to mildew like the latter and of stronger growth.

1-year - ". select for forcing .......

3-year. Select for forcing ....... 1.20

Chinense. A very pretty variety, with fine feathery foliage and intense gentian-blue flowers in open panicles

Chinense album. A pure white form of the above .................

Formosum. The old-fashioned dark blue Larkspur ................
Doz. $\quad 100$

15.00

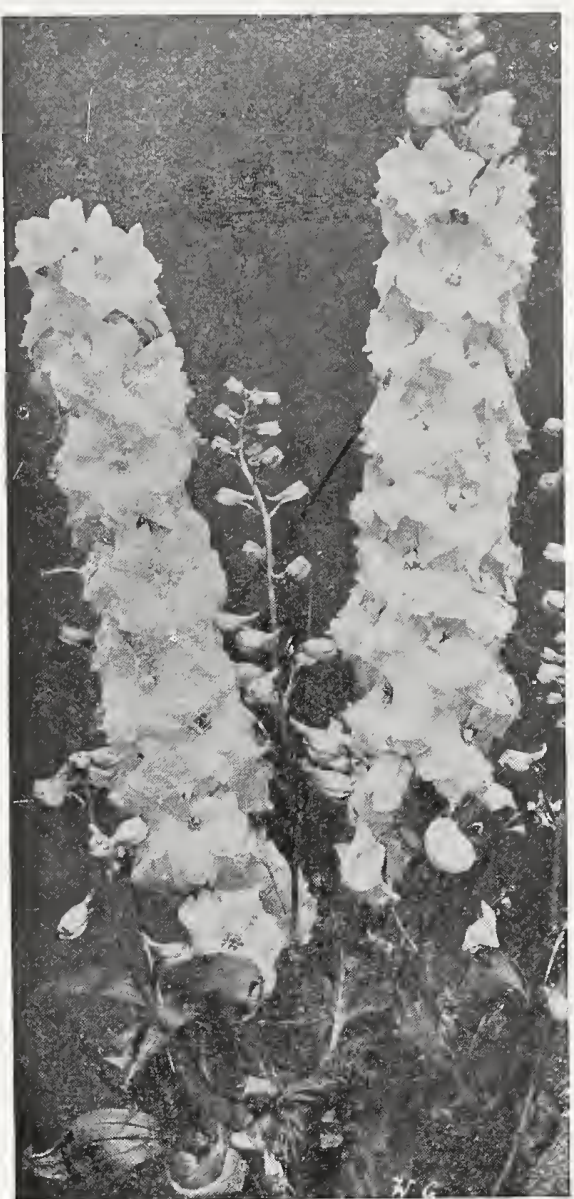

Delphinium, "Wayside Hybrids."

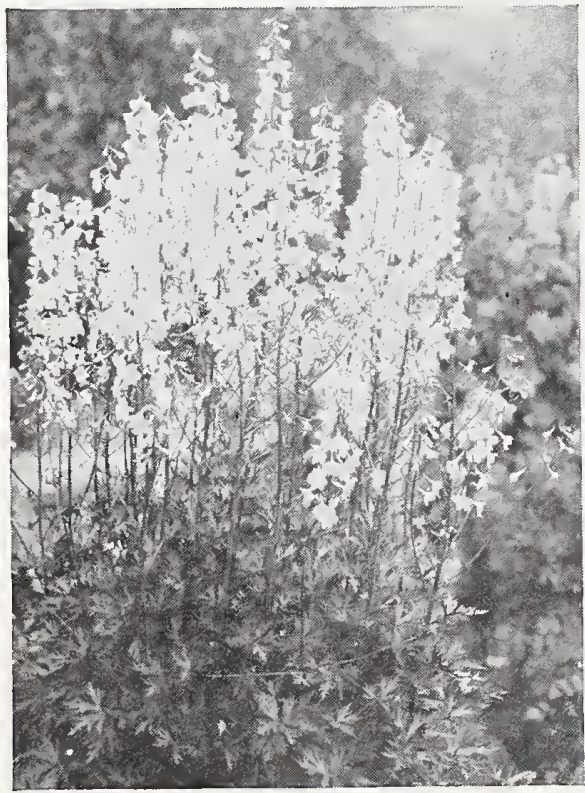

Delphinium Belladonna. 


\section{Terbaceous and Alpine Plants \\ te.}

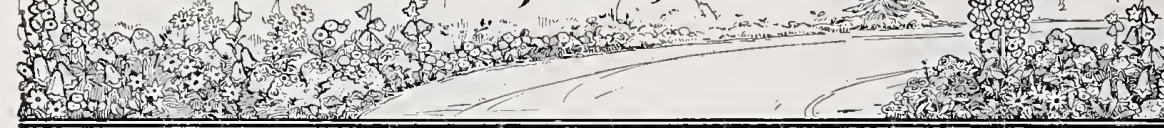

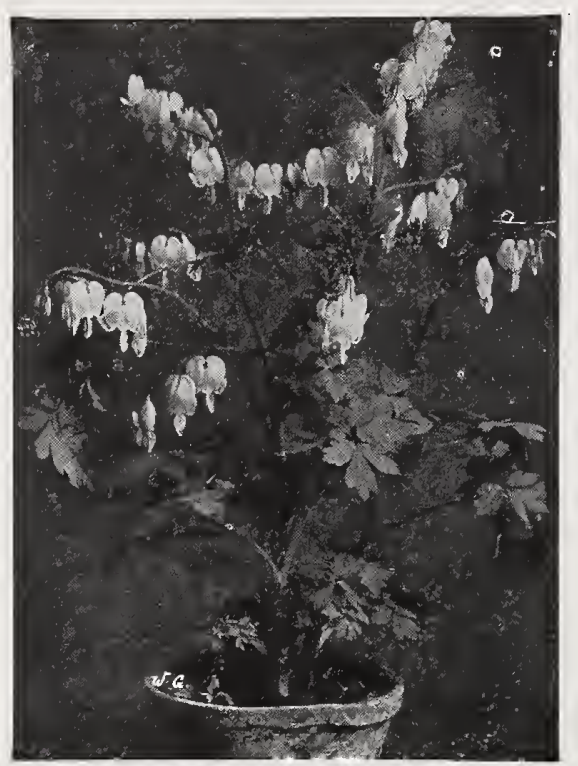

Dielytra-Bleeding Heart.

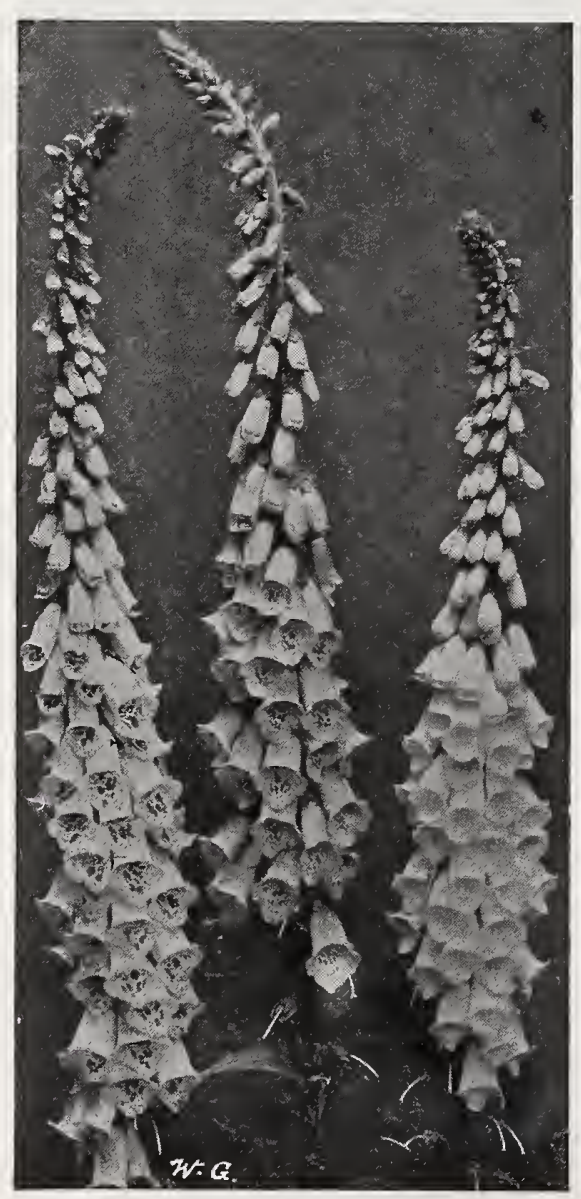

Digitalis, Shirley Hybrids.
DESMODIUM (Tick Trefoil).

Penaulifiorum An exceedingly Three Doz 100 graceful shrublike plant covered with purplish red flowers in Summer time when little else is in

bloom. Strikingly beautiful ...\$1.70 $\$ 5.00 \quad \$ 35.00$

DICTAMNUS (Gas Plant).

The Dictamnus is one of the most satisfactory hardy plants in cultivation, both on account of splendid flowers and its rich, durable foliage.

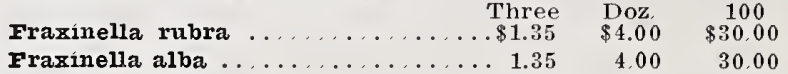

DIELYTRA OR DICENTRA (Bleeding Heart).

A hardy perennial with heart-shaped, rose-colored flowers in drooping spikes The base of the flower is furnished with two sheathlike spurs. One of the best border plants perfectly hardy and easily cultivated. Flowers in Apri or May. The bleeding Heart is one of the choicest members of the old-fashioned gardens. They prefer the shaded nooks in the border.

Spectabilis (Bleeding Heart or Seal

Three Doz. 100 Flower). An old-fashioned favorite; its long racemes of graceful heart-shaped pink flowers are always attractive; it is used largely for forcing, and is perfectly at for forcing, and is perfectly at home in any part of the hardy borplanting in clumps. Each, 60c. $\$ 1.70 \quad \$ 5.00 \$ 40.00$

Eximia (Plumy Bleeding Heart). A dwarf-growing sort, with beautiful finely cut foliage and showy racemes of pretty pink flowers racemes of pretty pink fow much cannot be said for this fine border cannot be said for this is is equally at home in full shade or sun and perfectly hardy anywhere. Bailey's "Encyclopedia of American Horticulture" says in description: "The handsomest foliage of any border plant in the entire collection." This variety of Bleeding Heart is the only kind which will replace the Spectabilis which is so hard to get. Will grow in any climate under any conditions.

$\begin{array}{llrr}\text { 2-year-old } & & \\ \text { 1-year-old (Strong) } \ldots \ldots \ldots \ldots \ldots \ldots & .20 & 3.50 & 25.00 \\ 2.50 & 15.00\end{array}$ DIGITALIS (Foxglove).

For stately and picturesque beauty it is not to be surpassed, and, planted in masses in the garden among shrubs or naturalized on the edge of woods, in the orchards or along brooks, it is extremely effective and satisfactory. It is a biennial, but, as it renews itself from self-sown seed, it may be treated as a perennial.

Giant Shirley Foxgloves. We were able to buy the first seed offered by the originator a year ago and now have a fine lot of field-grown plants of the Giant Shírley Foxgloves. They are a genuine "Shirley" prcduction of extraordinary size and vigor, growing 6 to 7 feet tall. The flower-heads are over 3 feet long. crowded with big, bell-shaped blossoms. Colors range from white and shell-pink range from white and shell-pink to deepest rose, many attractively dotted with crimson or chocolate. Furthermore, they are more apt old-fashioned Foxgloves $\ldots \ldots \ldots . \$ 1.00 \quad \$ 3.00 \quad \$ 20.00$

Ambigua or grandifiora. 2 to 3 feet. June and July. A hardy plant, with yellowish flowers, marked with brown. Effective in groups in wild garden $\ldots \ldots \ldots \ldots \ldots$........ and July. A popular variety, ranging in color from rose to deep purple. Robust habit .........

Gloxiniaeflora alba. 2 feet. June and July, The white-flowered Foxglove $\ldots \ldots \ldots \ldots \ldots \ldots \ldots \ldots \ldots \ldots \ldots \ldots \ldots$

Ianata. Dwarf variety; flowers are a deep purple ................

Mixed Colors. Fine new strain .... .85 


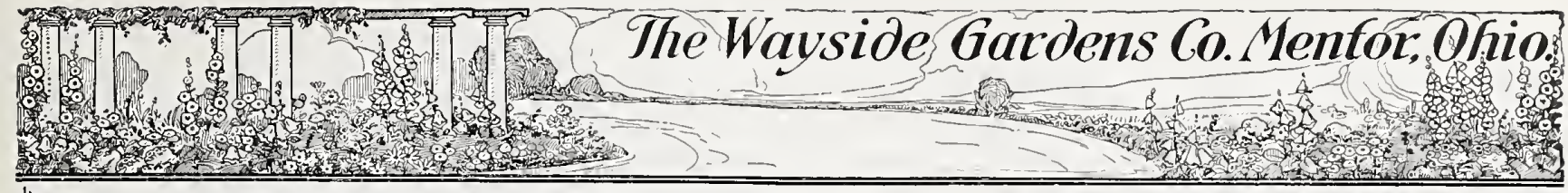

DIANTHUS (Pinks).

\section{HYBRID GARDEN PINKS}

Without the spicy fragrance of the Hardy Pinks a garden is incomplete. Their perfect form and rich coloring mak them great favorites for Summer bouquets. June.

Three Doz 100

Delicata (Double). Beautiful pink, $\$ 1.20 \quad \$ 3.50 \quad \$ 25.00$

misie. Deep rose-pink, flowers all

summer ..................... $1.20 \quad 3.50 \quad 25.00$

White Reserve. Continuous flow-

ering; pure white ......... $1.20 \quad 3.50 \quad 25.00$

Essex witch. Delicate pink; finely

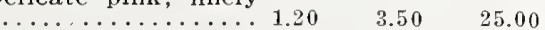

FIer Majesty. Very large: purest

$$
\text { white ........................ } 1.20 \quad 3.50 \quad 25.00
$$

\section{DIANTHUS AIIWOODI}

(New Perpetual-Flowering Hardy Pink).

This is a most important addition to our list of perennial plants. They are perfectly hardy and flower continuously from early Spring until late in Autumn; the flowers are much more substantial and larger than the old type of Hardy Pinks, and are borne on long stems suitable for
cutting: deliciously clove scented. All good, thrifty, young plants.

Robert. Old rose-pink with maroon $\cdots \cdots \cdots+\$ 1.35 \$ 4.00 \$ 30.00$ Jean. Pure white with violet center. $1.35 \quad 4.00 \quad 30.00$ Mixed. Single and double; all colors.

Strong, field-grown plants $\ldots \begin{array}{llll}1.35 & 4.00 & 30.00\end{array}$

\section{DIANTHUS PIUMARIUS (Clove Pinks).}

Pink purplish and white, fragrant flowers on long spikes. Handsome, glaucous green foliage. For border or rock garden. It will bloom continuously if flowers are cut off when they begin to fade.

Three Doz. 100 the Summer Blooms throughout $\$ 0.85 \quad \$ 2.50 \quad \$ 15.00$

\section{DIANTHUS HFDDEWIGI (Japanese Pinks).}

Flowers are very large and of the most brilliant colors, varying from pure white to the richest crimson, while many are beautifully laced or striped. For bedding purposes they are of immense value during the entire summer, and they also furnish elegant flowers for bouquets. Mixed varieties Three Doz. 100

\section{VARIOUS VARIFTYES}

Suitable for dry rockeries, dry walls or any other hot, dry, sunny spot. Almost all Pinks are of the easiest culture and will thrive in any well drained soil and sunny position.

Arenarius (Sand-Loving Pink) This Pink delights in a sandy soil and sun. Flowers white with carmine ring, deeply fringed and fragrant. Excellent for dry, hot

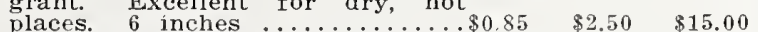

Caesius grandiflorus (Cheddar Pink). It is very compact in growth and makes a cushion of glaucous leaves from which, in May, spring the sweet smelling, rose colored flowers. It varies as much as from four ilıches to ten inches in height. It is easily grown and very fine for the rock garden. 6

inches $\ldots \ldots \ldots \ldots \ldots \ldots \ldots \ldots \ldots$.

Cruentus. Dense heads of flowers
on long stems. Deep red. Fine on long stems. Deep red. Fine

Deltoides (Maiden Pink). A beautiful little plant with narrow leaves and bearing a profusion of small, crimson flowers during June and July. Easily grown on rockery..

Deltoides albus. A charming white form of the above variety .....

Deltoides "Brilliant." Glowing crimson-red; a most striking rock plant ...........................

Speciosus. A free-flowering, lavender-pink variety; flowers are finely cut, giving a lacy effect; wonderfully sweet scented, growing anywhere like all other varieties under this heading; the hotter and
dryer the spot the more they are

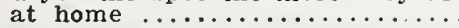

Three Doz. 100

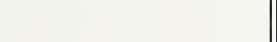

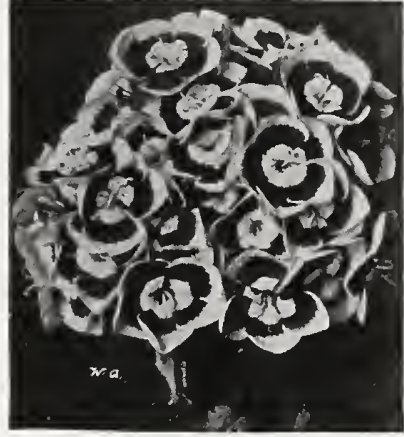

Dianthus Barbatus.

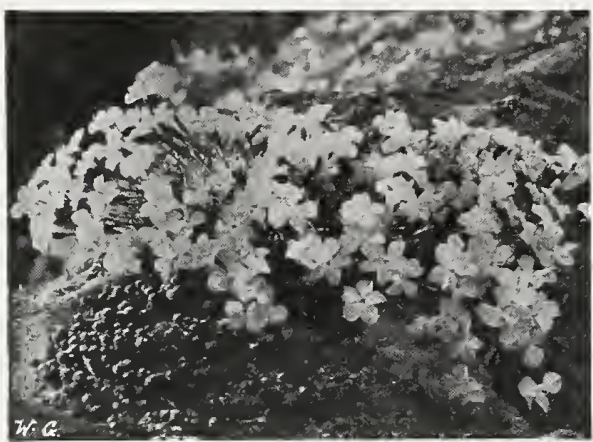

Dianthus Deltoides.

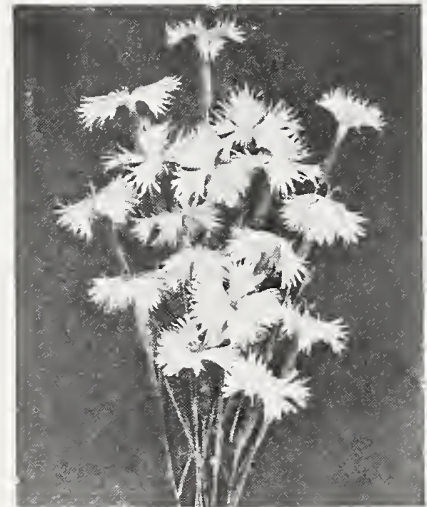

Dianthus Speciosus.

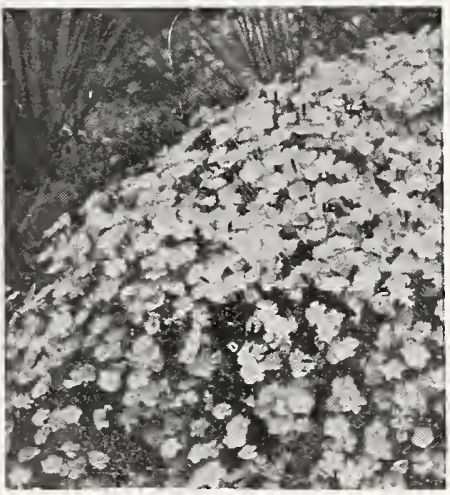

Dianthus Plumarius. 


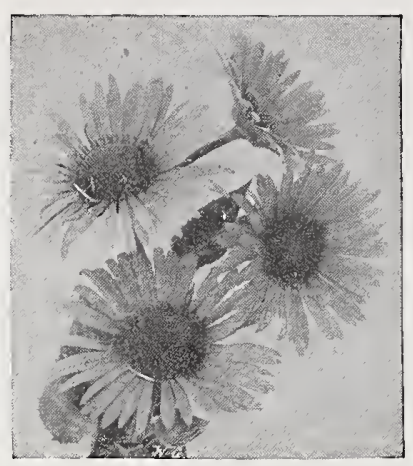

Doronicum.

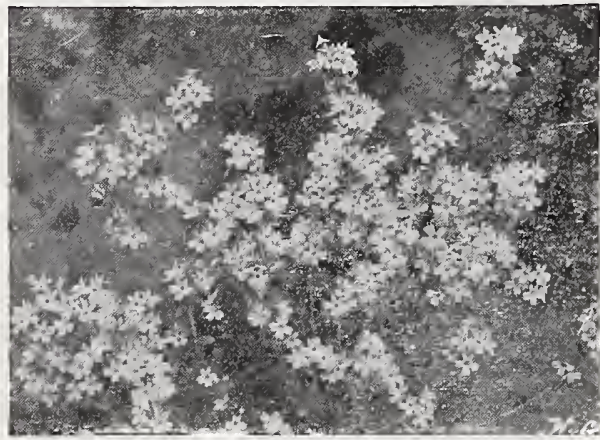

Erinus Alpinus.

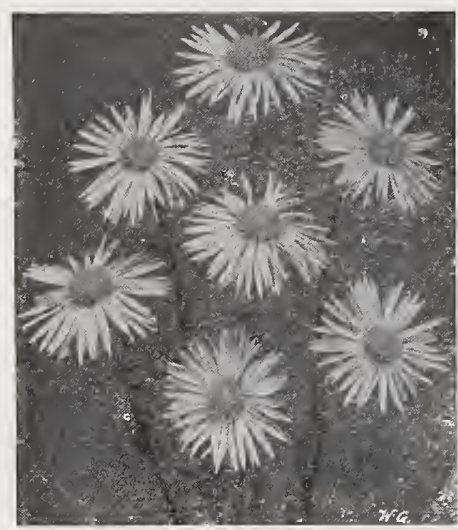

Erigeron.

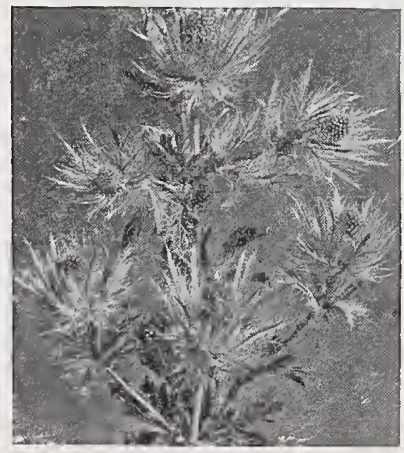

Eryngium.
DIANTHUS BARBATUS (Sweet William).

The Sweet William is a fine plant which produces great masses of bloom of extremely rich and varied colors. The flowers are lasting and fine for cutting.

Newport Three Doz. 100 or salmon-rose. 18 inches ...... $\$ 0.85 \quad \$ 2.50 \quad \$ 15.00$

Holborm Glory. A very fine auricula-

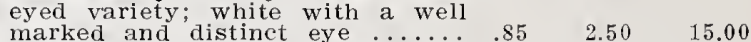
marked and distinct eye .......... scarlet Beauty. Rich deep scarlet, bright green foliage: very fine
Maroon

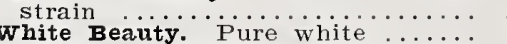

Iatifolius atrococcineus fl. pl. ( $\mathrm{Ev}$ erlasting Hybrid Sweet William). Beautiful Summer bedding variety producing masses of brilliant fiery crimson flowers all season.

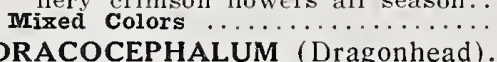

Very showy border plants when in flower. Hardy. Delight in a cool situation.

Ruyschianum japonicum. Flowers white; central lobe of corolla with a blue border and white spots, might be called a blue Physos tegia. 2 feet ............... \$1.00 $\$ 3.00 \quad \$ 20.00$

DORONICUM (Leopardbane).

Caucasicum. Large, bright yellow flowers; one of the most effective early Spring flowering perennials. Effective as a single plant, or in a hardy border. It is a splendid flower for cutting, as it carries well and stands a long time in water. They succeed well every-

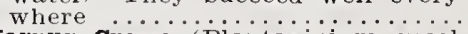

Harpur Crewe (Plantaginium excelsum). A much improved form of the preceding, having large, rich golden yellow flowers, of grand golden yellow flowers, of grand (For Fall, 1925, delivery) . . . $1.70 \quad 5.00 \quad 40.00$

ECHINACEA (Coneflower).

(See Rudbeckia Purpurea).

ECHINOPS (Globe Thistle).

Ritro. Interesting and showy thistlelike plants with globular heads of deep metallic blue flowers, which can be dried and remain attract ive for a long time. 2 to 3 feet.

EDELWEISS (See Leontopodium).

ERIANTHUS (Plume Grass).

(See Grasses).

EPILOBIUM (Willow Herb).

Angustifolium. Crimson flowers;

very showy among shrubbery. $100 \quad 3.00 \quad 20.00$

ERIGERON (Fleabane).

A very effective genus of Michaelmas Daisy-like plants usually with pink and purple flowers. They flourish in any garden soil, are indispensable for groups and flower borders, and are excellent for cutting. June to August.

Three Doz. 100

Antwerpia. Large, deep blue flow-
ers, 2 inches across .......... $\$ 1.00 \quad \$ 3.00 \quad \$ 20.00$

B. Iradhams. Beautiful mauve-pink; fine flowers; an entirely new and
pleasing color . . . . . . . . . . . $1.00 \quad 3.00 \quad 20.00$

Coulteri. Spreading masses of pure

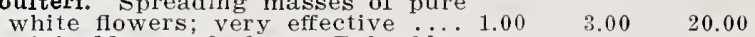

Fontainebleau. 2 feet. Pale blue with rich golden center; a new and striking color .............. $1.00 \quad 3.00 \quad 20.00$ mesa Grande. 18 inches. Violetblue; distinct from all others; fine for cutting . ............ $1.00 \quad 3.00 \quad 20.00$ (All the above are for Fall, 1925 delivery). Quakeress. Rosy lavender; free

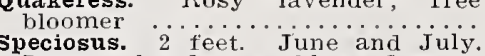
I,arge, handsome blue flowers, violet tinted and yellow centers..

\section{ERINUS.}

Alpinus. Pretty rosettes of foliage and racemes of rosy purple flowers. A first rate rock plant and also invaluable for establishing on old walls or between steps. inches. May-June ............ 1.20 


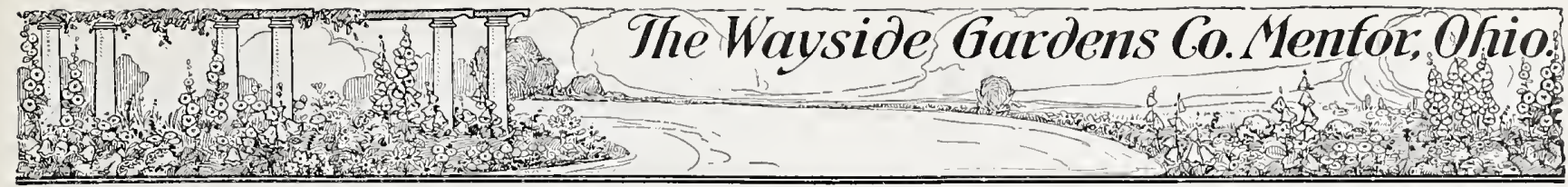

ERYSIMUM (Hedge Mustard).

These plants do well in the front row of a border and on dry banks. They like full exposure to sunlight, and in the spring months are completely covered with bright flowers. Pulchellum (Fairy Wallfower). Dwarf plant with suphur-yellow $\$ 0.85 \quad \$ 2.50 \quad \$ 15.00$ ER YNGIUM (Sea Holly).

Finely cut, spiny foliage and thistle-like heads of flowers of a beautiful steel blue. Very decorative in the hardy border, and useful for dry bouquets in Winter.

Amethystinum (syn. oliverianum) The true blue Thistle, with ame- $\$ 1.20 \$ 3.50 \$ 25.00$ thyst stems and bracts ….... $\$ 1.20 \quad \$ 3.50 \quad \$ 25.00$ EULALIA (See Grasses).

EUPATORIUM (Hardy Ageratum).

A splendid native plant growing 6 to 10 inches high; immense heads of purplish pink flowers: fine for naturalizing along streams and ponds, and for planting amon shrubbery. Three Doz. 100 Fraser: $\$ 0.85$

oelestinum. Lavender flowers. Au-

$$
.85 \quad 2.50
$$

EUPHORBIA (Milkwort).

Corollata (Flowering Spurge). Showy and useful native plant growing about 18 inches high, and bearing from June till August umbels of pure white flowers with a small $-00-3.00-20.00$
0 Myrsinites. A pretty prostrate species, bluish foliage, with $1.00 \quad 3.00 \quad 2000$ FERNS (Hardy Varieties).

The cultivation of Hardy Ferns is remarkably simple. All they want is a light alluvial soil, a little loam and peat or leaf-mould sufficient to keep the soil light and open, plenty of moisture, positions varying from partial to deep shade. The Aspleniums and many others will grow on walls, chinks of rocks, etc. Many will revel in full sunshine in any ordinary border. There is scarcely a garden or even a back yard where Ferns cannot be grown successfully. Anyone commencing with a few specimens will soon be induced to go on collecting until he has made a feature both interesting to himself, and also to all who see them Adiantum pedatum (Hardy Maidenhair Fern). Most attractive of
our native Ferns; black stems with delicate green flonds $\ldots \ldots \ldots 0.85 \quad \$ 2.50 \quad \$ 15.00$ Aspidium acrostichoides (Wood Fern). (Polystichum). An everdivided fronds. Should be planted in a shady position. 12 inches

Aspidium spinulosum (Dryopteris spinulosa). Spinulosa Woodfern. quires rich, well drained soil. 18 to 24 inches

Asplenium filix " foemina iLady Fern). Grows in shade or sun. Large and handsome 3 feet $\ldots$.

Dicksonia punctilobura (Dennstaed-
tia punctilobula). Hay-Scented or tia punctilobula). Hay-Scented or Gossamer Fern. Grows well in inches. Very erect with broad fronds, of a soft, woolly texture.

Onoclea sensibilis (Sensitive Fern). Requires wet places either in sun or shade. 12 inches ..........

trich Fern germanica araceful species with finely eut pinnules, growing 2 to 3 feet high .......

osmunda claytoniana (Interrupta). $A$ distinct and very beautiful native species; foliage velevty green, with prominent brown spores in middle of fronds .... Each, 30c.

cinnamomea (Cinnamon Fern). Erect fronds, drooping at tips, with bright cinnamon colored spores at end of fronds; a very conspicuous variety Each, $30 \mathrm{c}$. derful in damp, marshy places, where its rich yellowish green foliage and olden stems make very striking subjects. Wach, $30 \mathrm{c}$.

woodsia obtusa. Laron rosettes one foot in length: very freeone foot in length; very free- $\begin{array}{lll}85 & 2.50 & 15.00\end{array}$

$85 \quad 2.50-15.00$

\begin{tabular}{l}
$85-2.50-15.00$ \\
\hline
\end{tabular}

$85 \quad 2.50 \quad 15.00$

$\begin{array}{lll}85 & 2.50 & 15.00\end{array}$

$85 \quad 2.50-15.00$

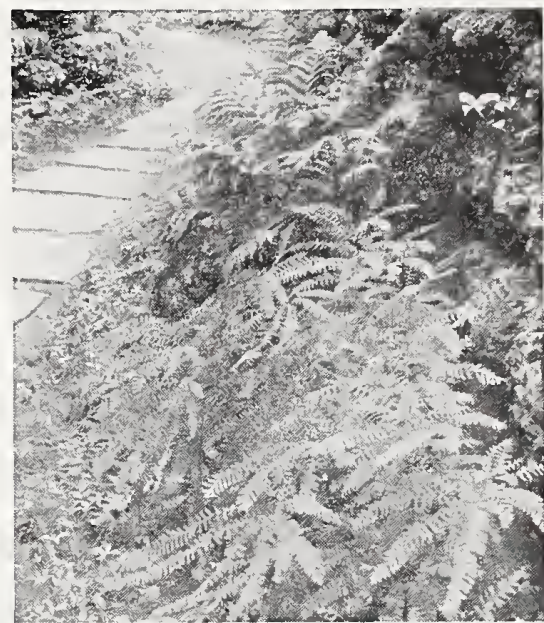

Ferns.

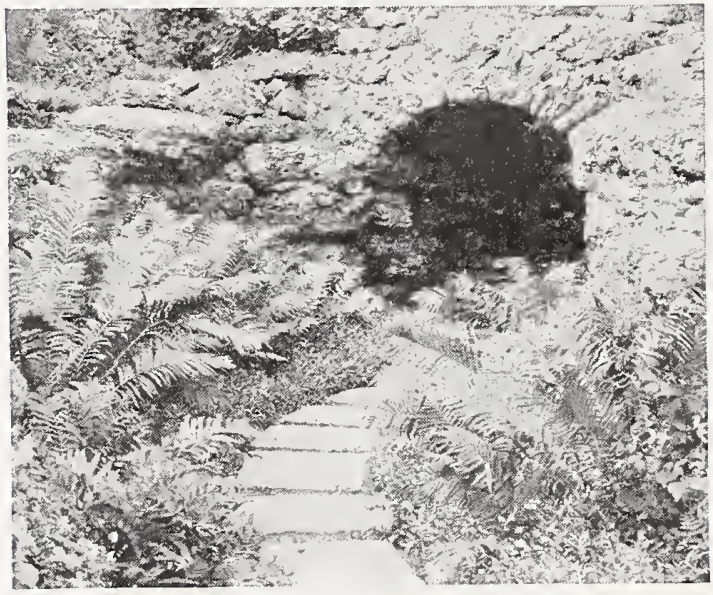

Ferns.

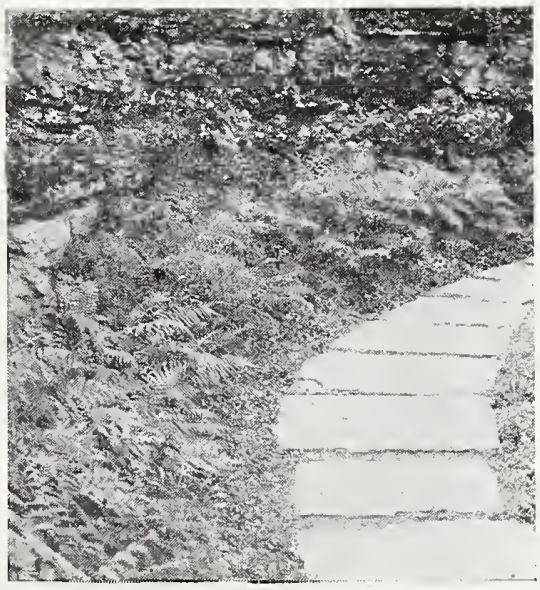

Ferns. 


\section{Herbaceous and Alpine Plants}

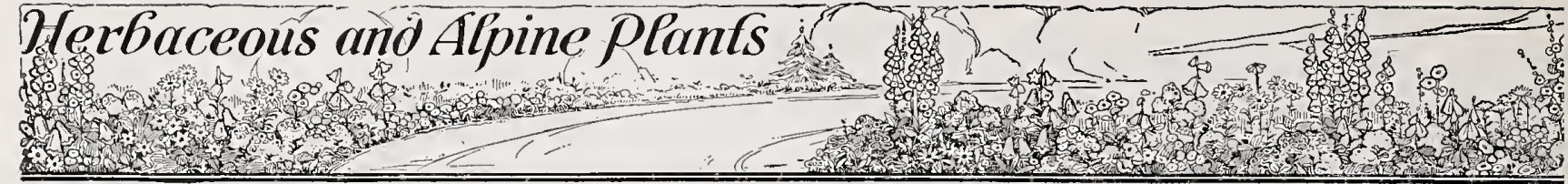

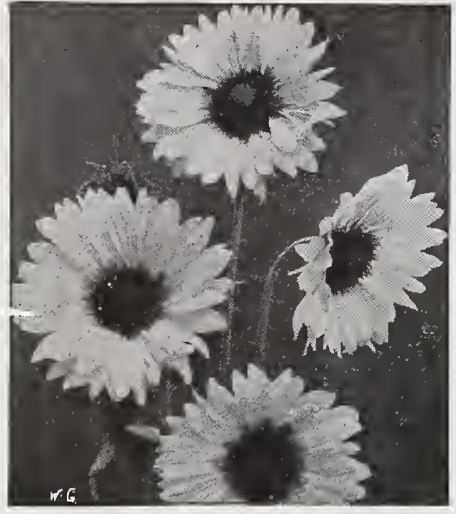

Gaillardia, Improved English.

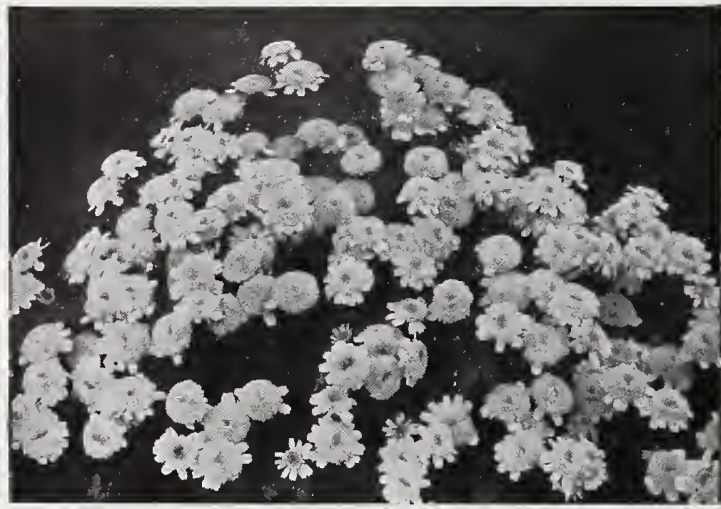

Feverfew-Matricaria.

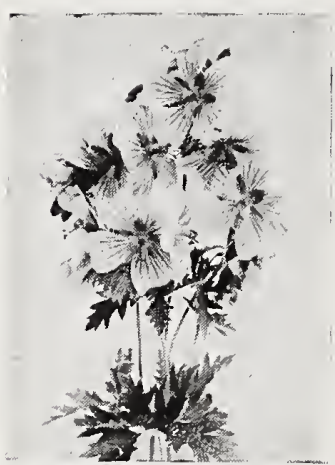

Geranium Ibericum.

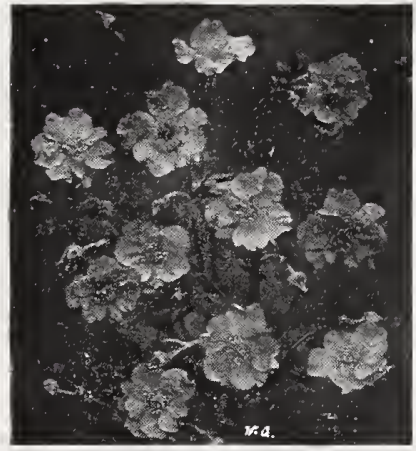

Geum, Lady Stratheden.
FEVERFEW (Matricaria).

Three Doz. 100

plant and valuable Summer cut
flower, with large, double, white

flower, with large, double, white
flowers. June until October. 18

flowers. June until October. 18
to 24 inches $\ldots \ldots \ldots \ldots \ldots \ldots \ldots \ldots .85 \$ 2.50 \quad \$ 15.00$

Golden Ball Dwarf yellow ..... $85 \quad 8.50 \quad 15.00$

FOXGLOVE (See Digitalis).

FUNKIA (Plantain Lily).

The Plantain Lilies are among the easiest plants to manage; their broad, massive foliage makes them attractive subjects for the border even when not in flower. They succeed equally well in sun or shade

Three Doz. 100

leaved ................\$1.00 \$3.00 \$20.00

Coerulea. Broad green leaves; blue

flowers in June .................. $85 \quad 2.50 \quad 15.00$

Glauca. A very pretty Japanese species, with distinctive bluish

foliage $\ldots \ldots \ldots \ldots \ldots \ldots \ldots \ldots \ldots \ldots 1.70 \quad 5.00 \quad 40.00$

subcordata grandiflora. Very large

pure white, lily-shaped, fragrant

flowers in August and September. $1.35 \quad 4.00 \quad 30.00$

variegata. Variegated folıage; blue

flowers. Beautiful edging plant .. $.85 \quad 2.50 \quad 15.00$

GAILLARDIA (Blanket Flower).

Improved English Strain. We corisider the Gaillardia one of the most desirable hardy plants in cultivation and our strain of these brilliant flowered plants to be the finest extant. Though such an ornamental adaition to the herbaceous border, the perennial Gaillardia is content with extremely simple treatment. Dig the soil deeply and enrich with well-rotted manure. We recomimend the Gaillardia for bedding purposes as well as for borders. Everyone will have noticed how grandly Gaillardias have thriven through droughts. they seem hardly to need water. The ofusion scarcity of other flowers the more the utility of the and brilliant sight can be imagined than a large bed of Gaillardias, with their profusion of highly colored flowers of all shades. Some of the varieties of our improved strain measure fully 5 inches in diameter.

Choicest Mized Colors ........ Three $\begin{array}{ccc}\text { Doz. } & 100 \\ \$ 0.85 & \$ 2.50 & \$ 15.00\end{array}$

GENTIANA (Blue Gentian).

Andrewsi. One of the most fascinating native plants. The flowers, which are tightly ciosed, are borne at the top of a stem from 6 to 8 inches long, and are an in-

tense deep blue. Blooms best in
moist places. July and October.. 1.00

Thibetica. Very hardy variety; creamy white .............. $1.00 \quad 3.00$

GERANIUM (Crane's Bill).

Iboricum. Handsome serrated foliage. Large, lilac-blue flowers, blooming ali Summer; compact, bushy plants. 18 inches ........ .8

15.00

Sanguineum album. Fine rock plant. 1,00

3.00

20.00

GEUM (Avens)

Coccineum Mrs. Bradshaw (Chiloense). A splendid new variety, with large, double flowers of a fiery red, blooming nearly all Summer. Peculiarly attractive. 18

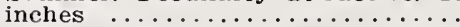

rady stratheden. A new introduction of great merit. Rich golden yellow blossoms, counterpart of hardy garden ............... 1.0

GILLENIA (Bowman's Root).

Trifoliata. A strong growing plant admirable for the border or for use in connection with shrubs, with handsonie trifoliate foliage and numerous white flowers tinged with pink whit feet ........ 


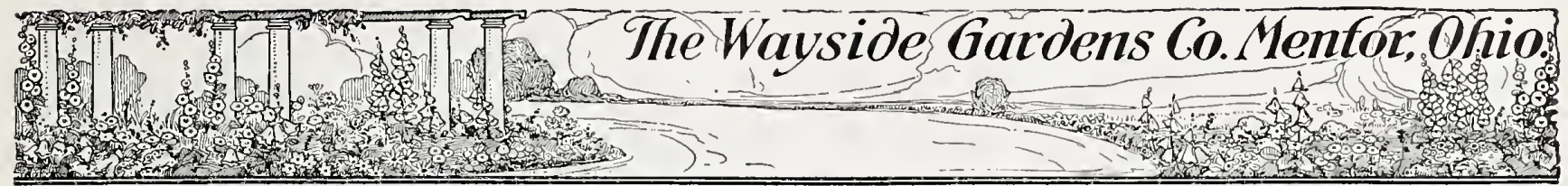

GRASSES (Hardy Ornamental).

The ornamental grasses can be used with telling effect in borders, large beds, or by the margin of ponds and lakes. They are of ten used with small shrubs and medium sized trees in wide borders. The Eulalias plante 1 singly on lawns where the soil is deep and rich, take care of themselves and grow rapidly into large specimens. In lare round beds, with ornamental rasses as the princilar as Cannas or dwarf-flowering plants the margin.

Three Doz 100

Handsome grass with narrow

glaucous silvery foliage. Well

adapted for the border or edge of
beds with taller sorts $\ldots \ldots \ldots \ldots . \$ 0.85$

Erianthus ravennae (Plume Grass or Hardy Pampas). 10 to 12 feet to 50 flower spikes. Closely resembles Pampas Grass ......... $1.20 \quad 3.50 \quad 25.00$

Eulalia gracillima univittata (Japan Tush). Graceful habit, with very rarrow foliage; of a bright green color, with a silvery midrib. 6 to

$$
7 \text { feet } \ldots \ldots \ldots \ldots \ldots \ldots \ldots \ldots \ldots \ldots \text {. }
$$

Eulalia japonica. Long, narrow, graceful green foliage, and when in flower the attractive plumes

are 6 to 7 feet high ........... ornamental; long, narrow leaves,
striped green, white, and often striped green, white, and often 1.00

Fulalia japonica zebrina (Zebra Grass). The long blades of this variety are marked with broad, yellow bands across the leaf. It yellow bands across the lear. It makes a very attractive specimen
plant for the lawn. 6 to 10 feet.

Festuca glauca (Blue Fescue Grass). 12 to 15 inches. Ornamental grass. Grown for dense tufts of very narrow bluish leaves. Used for edgings or for contrast with darkedgings or for contrast with darkgarden $\ldots \ldots \ldots \ldots \ldots \ldots \ldots \ldots$.

Pennisetum japonicum (Fountain Grass). A beautiful grass whose flower heads are produced in the greatest profusion. Color rich with white $\ldots \ldots \ldots \ldots \ldots \ldots . . . . .1 .00$

Phalaris arundinacea variegata (Variegated Ribbon Grass) Leaves longitudinally striped with white: very ornamental; sometimes run

GYPSOPHILA (Baby's Breath).

Very branching or spreading, slender plants, with scant foliage when in bloom. Of easiest culture in open, rather dry places. Desirable where a mass of delicate, misty bloom will fill in a bare place.

Three Doz. 100 bloom in August and September bloom in August and September it forms a symmetrical mass 2 to 3 feet in height and as much having a beautiful gauzelike ap-

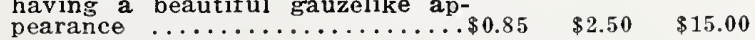

Rokejeka (Acutifolia). Rose colored "Baby's Breath." Tall, graceful grower, and a wonderful cut

flower $\ldots \ldots \ldots \ldots \ldots \ldots \ldots \ldots \ldots$

Repens. A beautiful trailing plant small, white and pink flowers in Suly and August pink fowers in

Paniculata flore pleno. A light and graceful cut flower, compatible graceful cut flower, compatible with all others, no matter of what shape or color; masses of minute double white flowers. (Plants offered are grafted, and we guar-
antee all plants sold to be double). 1.70

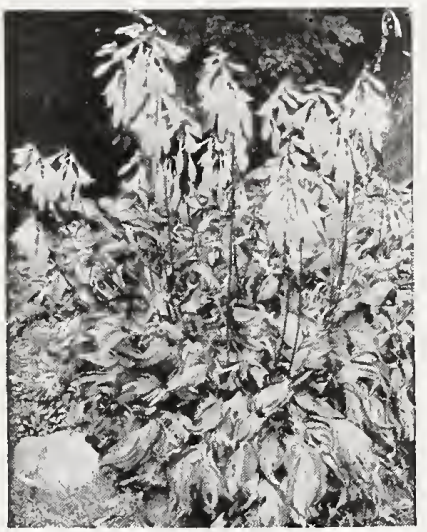

Funkia Variegata.

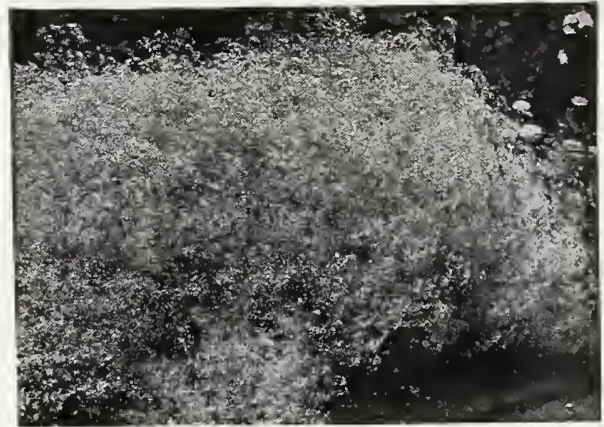

Gypsophila Paniculata.

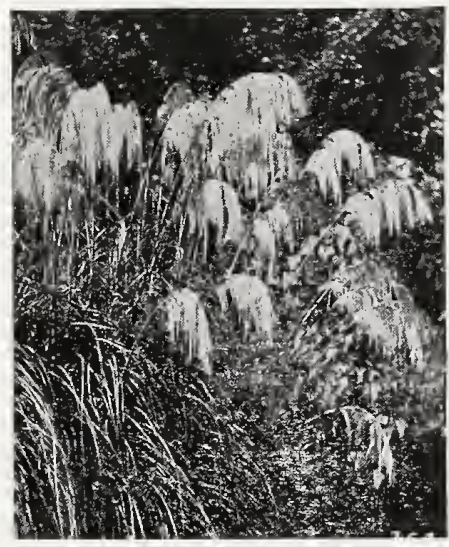

Pampas Grass.

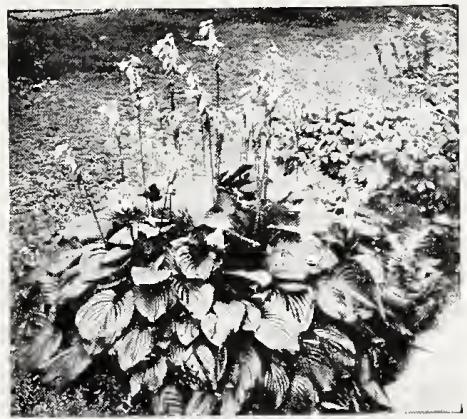

Funkia Coerulea. 


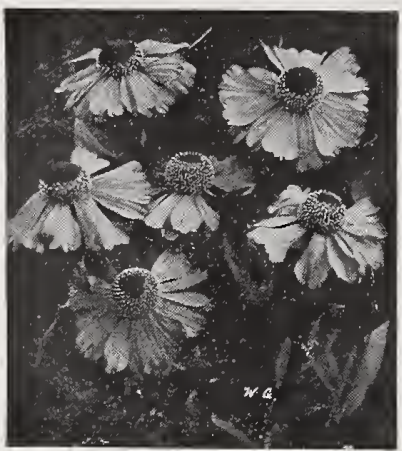

Helenium.

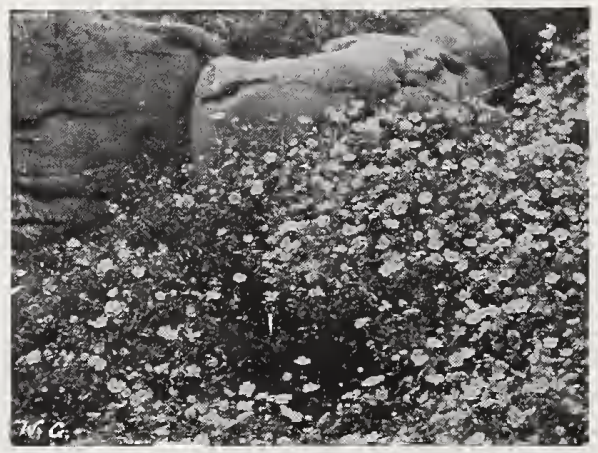

Helianthemum.

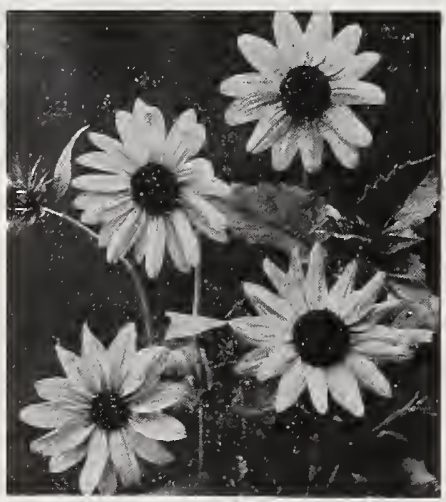

Helianthus.

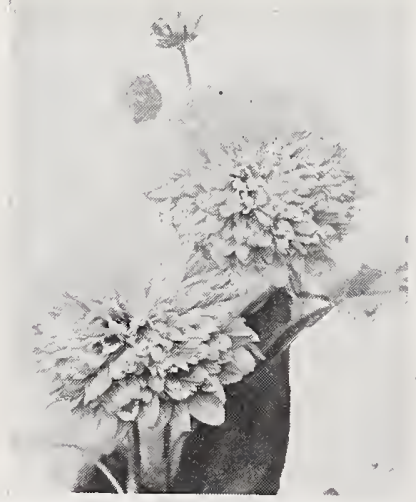

Helianthus Multiflorus fl. pl.
HELENIUM (Sneezewort)

Tall growing plants closely allied to the Sunflower; bearing in late Summer and Fall great masses of large, daisylike flowers in shades of yellow and orange.

Three Doz. 100 of deep golden yellow flowers in late Summer. Grows 5 to 6 feet high ........................... $\$ 1.00 \quad \$ 3.00 \quad \$ 20.00$

Autumnale rubrum. A splendid new variety; deep ox-blood-red, changing to terra cotta. 5 to 6 feet.

September $\ldots \ldots \ldots \ldots \ldots \ldots \ldots \ldots$.

Bigelovi. Quick growing, branching
plants, 2 to 3 feet; quite showy plants, 2 to 3 feet; quite showy during August with terminal clus-
ters $1 \frac{1}{2}$ inches, deep yellow flow-

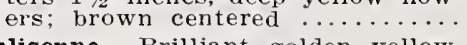

Julisonne. Brilliant golden yellow with brownish center; new and very distinct ................... $1.50 \quad 4.00 \quad 35.00$

Pumilum magnificum. Large, golden yellow flowers; one of the most floriferous and useful border plants in cultivation .............

Pumilum aurantiacum (New). Large, bright yellow flowers, possibly better than the preceding .......

Riverton Beauty. Pure lemon-yellow, with large dise of purplish

Riverton Gem (New). Old gold, suffused with bright terra cotta, changing to wallfower-red. August to October .............

wyndley. A grand, bushy variety, with large, spreading heads of wolden yellow flowers, shot and golden yellow flowers, shot and
stained with reddish mahogany. 3 $3.50 \quad 4.00 \quad 35.00$
feet $\ldots \ldots \ldots \ldots \ldots \ldots \ldots \ldots \ldots \ldots \ldots$

HELIANTHUS (Hardy Sunflower).

The perennial Sunflower should always be planted in masses, where they may have plenty of room, against background of shrubbery, or naturalized in wild gardens back or woodiands. In combination with hardy Asters, where to describe. In combination with hardy Asters, where few equals. They are profuse bloomers, producing an unlimited supply of flowers for decoration.

Acutifolius. An extremely beautiful October variety, with large flowers of a delightful shade of golden yellow .............. \$0.85 \$2.50 $\$ 15.00$

Miss Mellish. An improved variety of Helianthus lactiflorus; of taller growth and having larger flowers. A decided improvement and most

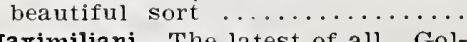
Maximiliani. The latest of all. Golden yellow flowers in graceful
sprays in October. Fine for cutsprays in October. Fine for cutMultiforus fl. pi. clear yeliow; closely resembling a Dahlia in shape and finish. 4 feet $\ldots \ldots \ldots$. Sparcifolius. The best of the Summer-blooming varieties of hardy Sunflowers. Flowers 3 inches in diameter and freely produced. Plant grows 3 to 4 feet high, and der, and for planting among der, and for planting among $1.00 \quad 3.00 \quad 20.00$

HELIANTHEMUM (Rock or Sun Rose).

Low-growing evergreen plants, forming broad clumps, and which during their flowering season, July to September, are hidden by a mass of bloom; for the front of the border, the rockery, or a dry, sunny bank. $\ldots \ldots \ldots \$ 1.00 \quad \$ 3.00 \quad \$ 20.00$

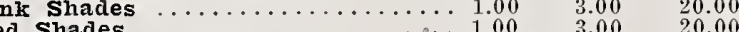

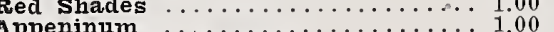

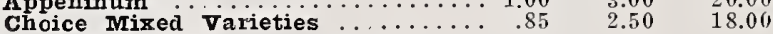

HEPATICA (Liver Leaf).

Coerulea. A pretty native, Springflowering plant, with blue flowers: prefers shade, but will do fairly well in an open situation in moist, rich loam. We offer large, established clumps, each consisting of about 6 large crowns ..........85 $\quad .850 \quad 15.00$ 


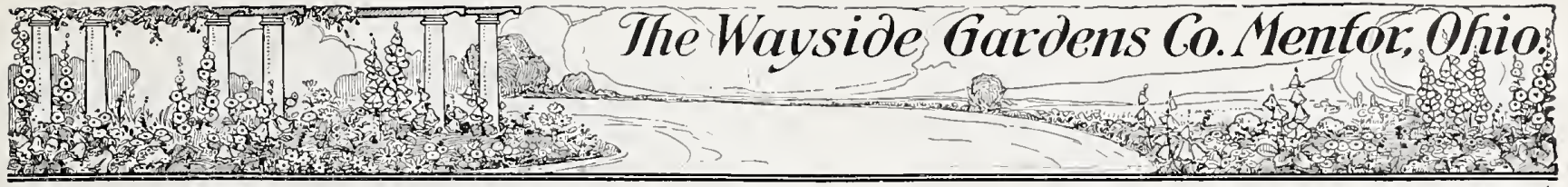

HELIOPSIS (Hardy Zinnia).

Similar in (Heneral habit to Helianthus, but commencing to flower earlier in the season. July and August. Of dwarfer habit, rarely exceeding 3 feet in height. Very valuable for cutting.

Pitcheriana. A desirable variety.

Three Doz 100 The flowers are of a beautifui deep golden yellow, about two inches in diameter, very thick texture and a useful cut flower..\$0.85 $\quad \$ 2.50 \quad \$ 15.00$

Scabra excelsa. A new variety with very rich chrome yellow flowers, turning to a bright yellow as they mature. These are almost double, having from 4 to 5 rows of petals, and are produced very profusely. The plant is about 3 feet high and from mid-July to the end of Septembor makes an effective dis-

play ................... $1.20 \quad 350$

HEMEROCALLIS (Yellow Day Lily).

Hemerocallis have long been favorites in our garden, and are always included in any list of the most popular hardy plants. All of the varieties of Hemerocallis are desirable and beautiful. The tall, graceful, grasslike foliage is very handsome and sets off the charming lily-like flowers very effectively. They look particularly well naturalized along streams or on moist banks, and will thrive most luxuriantly in shade.

Flava (Lemon Lily). Sweet scented, clear, full yellew; $21 \%$ feet. Flowers in June ............... \$0.85 \$2.50 \$15.00

Fulva (Brown Lay Lily), Coppery orange, shaded crimson. 3 feet. July $\ldots \ldots \ldots \ldots \ldots \ldots \ldots \ldots$

Dr. Regel. Handsome, rich orangeyellow flowers in May. Very fragrant. Fine for cutting. $1 \frac{1 / 2}{2}$ feet.

Thunbergi. Much like Flava, but flowers in July, a month later, and 6 to 10 inches of the upper portion of the flower scapes are thickened

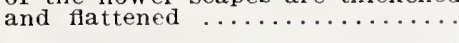

Florham. A strong grower, 3 to $31 / 2$ feet high, large, trumpet-shaped flowers; rich, golden yellow, with Indian yellow markings. June and

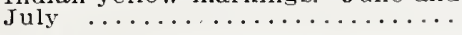

Kwanso. Large, double-flowered variety, with rich, golden bronze flowers $\ldots \ldots \ldots \ldots \ldots \ldots \ldots \ldots \ldots \ldots$.

Middendorfi major. A very striking
variety, with huge rich, orangevariety, with huge rich, orange-
yellow flowers $\ldots \ldots \ldots \ldots \ldots \ldots$

HESPERIS (Sweet Rocket).

Matronalis. 2 to 3 feet. June and July. Fragrant purple flowers in showy spikes. Desirable for wild garden, shrubbery or mixed border.

HEUCHERA (Coralbells).

Beautiful plants for front row of borders, with slender, fairy-like spikes of richly colored flowers: most striking in the garden and light and graceful for cutting. Americana. $11 / 2$ to 2 feet. July. A native plant with greenish yeliow gowers; foliage motted.

Brizoides. We have thoroughly tested this new Heuchera and find it one of the most desirable hardy plants introduced in many years. It has the same foliage and habit as Heuchera sanguinea, but the as the is not so brilliant, though five or six timo brillant, though five or six times as many nowers $120 \quad 3.50 \quad 25.00$

Sanguinea. 12 to 18 inches. June to September. Flowers bright crimseptember. Free-flowering. Nice for cutting. Excellent for rock garden. 1.20

Sanguinea Mixed Hybrids. All shades of red and coral ..................

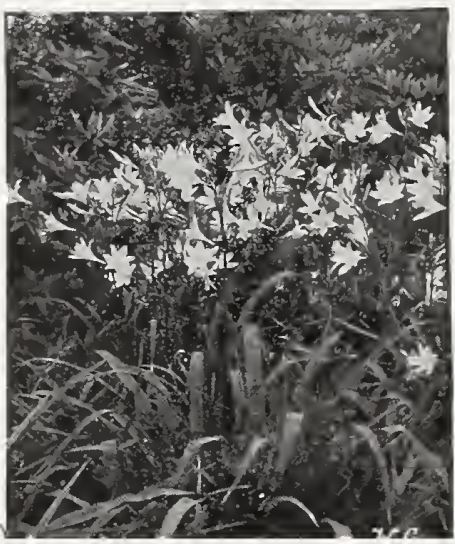

Hemerocallis Thunbergi.

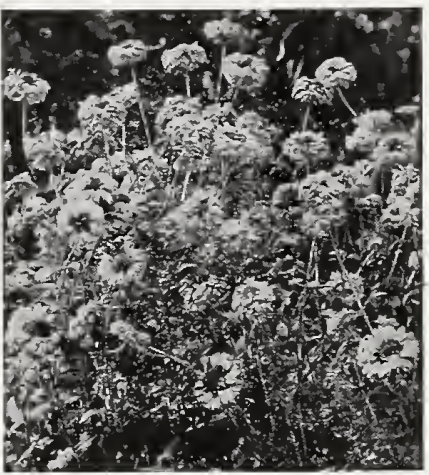

Heliopsis.

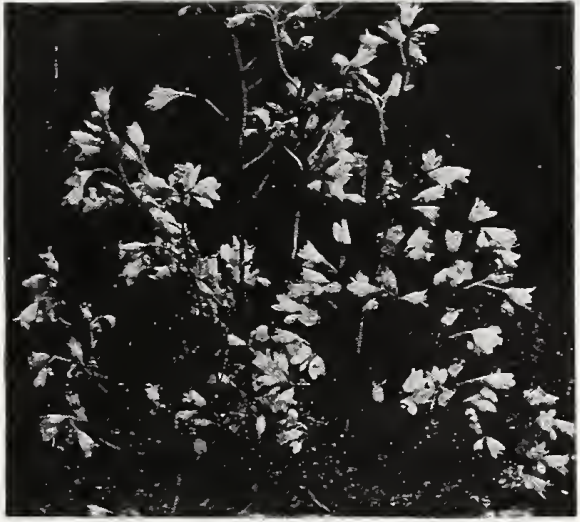

Heuchera Hybrids.

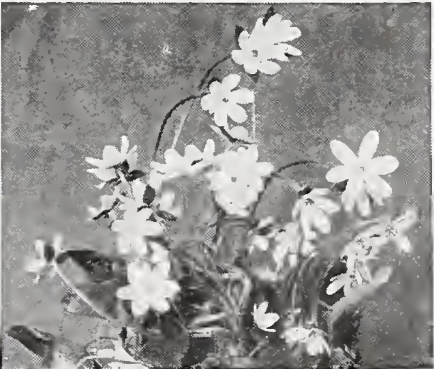

Hepatica Coerulea. 


\section{Terbaceous and Alpine Plants}

\section{(6)}

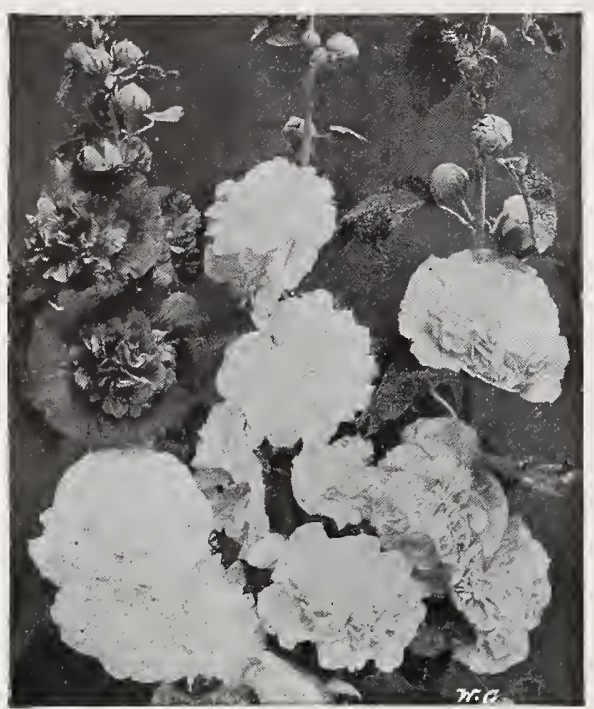

Double Holiyhock.

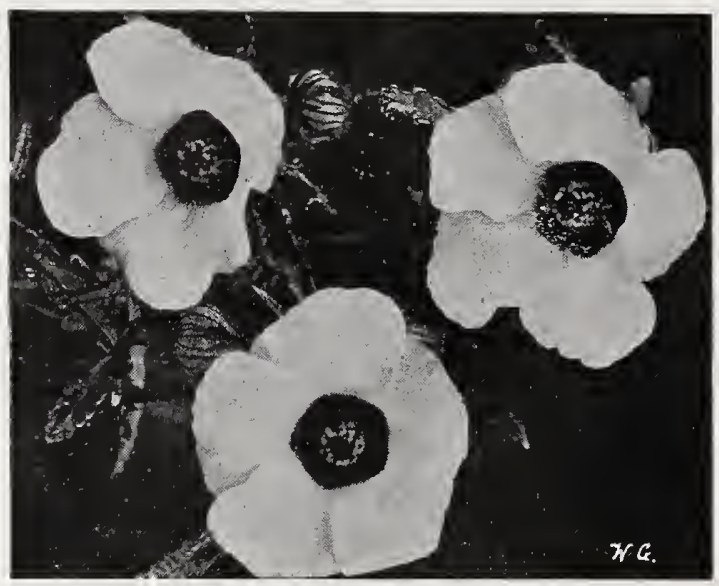

Hibiscus, Crimson-Eye.

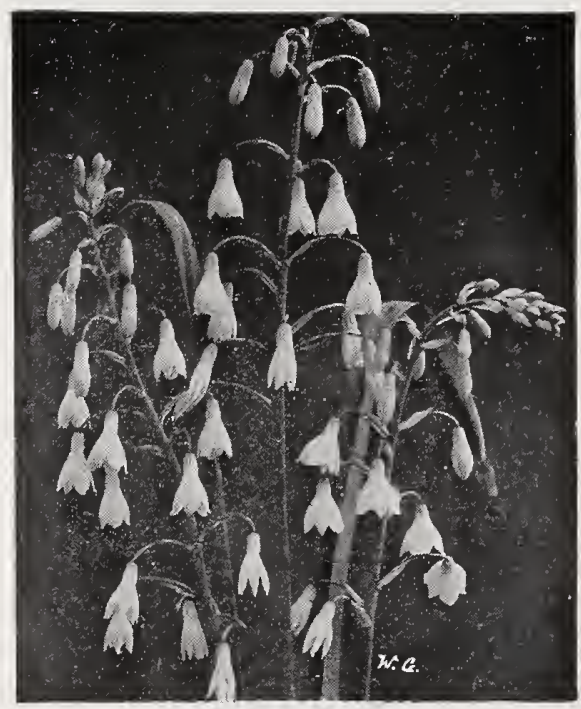

Hyacinthus Candicans.
HOLLYHOCKS (Althea Rosea).

The Hollyhock is an old garden favorite, full of sentiment and association with a distant past. It is a plant of strong vigorous growth and noble aspect, with elegant camellia-ike flowers that form perfect rosettes of the most lovely shades of color. They require a deep, rich most lovely shades of color. They require a deep, rich and lavish bloom all the attention bestowed upon them. Painters choose Hollyhocks as subjects for floral paintings of tener than any other flower. We suppose the reason for this is that artists have a keener appreciation of beauty than other people, and recognize that the common single Hollyhock is one of the most stately, picturesque and beautiful plants in the world. Nothing can be more effective than a large group of single Hollyhocks, and once planted they will literally take care of themselves even if planted in the grass. We know of patches that have not been cultivated or disturbed in any way for have not been cultivated or disturbed in any way for more beautiful than single. They are mistaken, although the doubles are beautiful, but inclined to be topheavy. Hollyhocks planted in the Fall will bloom the following Summer.

Double, Three Doz. 100 roon, white, yellow, pink, Newport

pink, white with purple base,

bright rose, dark purple, apple

blossom, pale lilac .......... \$0.85 $\$ 2.50 \quad \$ 15.00$

New Allegheny. Immense semi-

$\begin{array}{llll}\text { double flowers, with fringed edges. } & .85 & 2.50 & 15.00\end{array}$

single. Red, white, pink and mixed. (Our Hollyhocks are free from disease and rust. Clean, strong, one-year-old stock: two-year-old
plants are never sent out, as they

are not satisfactory) ...........

$.85 \quad 2.50 \quad 15.00$

HIBISCUS (Mallow).

Mallow Marvels. A robust type of upright habit, producing an abundance of flowers of enormous size in all the richest shades of crimson, pink and white.

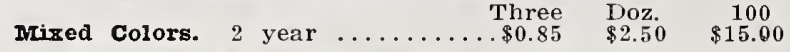

Moscheutos (Swamp Rosemallow).

Flowers 6 inches in diameter. Red

or pink. 2 year...$\ldots \ldots \ldots \ldots$.

Moscheutos "Crimson Fye." Flowers of immense size; of the purest white, with a large spot of deep velvety crimson in the center ...

New Giant-Flowering Marshmallow. A wonderfully improved form of our greatly admired native Marshmallow or Rosemallow, in which not only the colors have been
greatly intensified, but in which flowers of enormous size, frequently 10 to 12 inches in diameter, have been developed. Equally at home in all positions, having the same vigor in dry and wet ground; perfectly hardy and are very in July until late in September. They are the most beautember. They are the most beautiful and hardy of all herbaceous huge blossoms make them indispensable for large groups and mixed borders. We offer three distinct colors.

Red, Pink or white. Strong threeyear-old $\ldots \ldots \ldots \ldots \ldots \ldots \ldots \ldots$

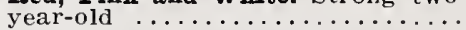
$.85 \quad 2.50 \quad 15.00$ $85 \quad 2.50 \quad 15.00$ ERACIUM (Hawkweed).

Aurantiacum. 6 to 12 inches. June to October. Small clusters of dandelion-like flowers; orange shaggy in tufts near ground ....

85
$2.50 \quad 15.00$

\section{HYACINTHUS CANDICANS.}

Twenty to thirty white, pendent, bell-shaped flowers on stalks 3 to 4 feet high. Blooms early and till late Fall. One oi the best of all hardy bulbs for the herbaceous

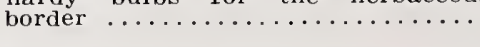

$1.20 \quad 3.50 \quad 20.00$

$.85 \quad 2.50 \quad 18.00$ 


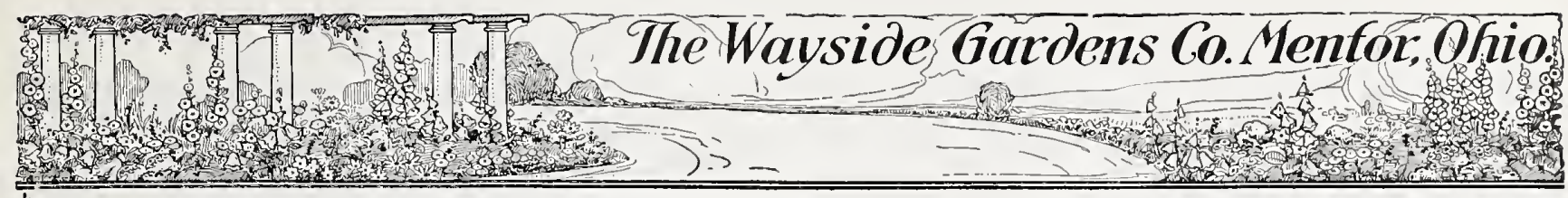

HYPERICUM (St. John's Wort).

Moserianum. A most desirable border plant, of free and graceful habit, producing long, slender, much branched ster.s, leafy to the base and all drooping towards the ends, apparently from the veight of the nowers and buds. althe so none of their beauty is lost. It is marelously free flowering, of large size, measuring from 2 to 21 inches in diameter, in eolor a rich golden yellow, rendered still more effective by the numerous yellow stamens and crimson anthers, and blooms continuously the entire season. 2 feet ............\$1.35 \$4.00 $\$ 30.00$

Henryi. The same as Moserianum, though slightly more upright in growth and much hardier and

better suited for cold climates .. $1.50 \quad 4.50$

5.00

IBERIS (Hardy Candytuft).

Most desirable dwarf plants, 8 to 10 inches, with evergreen foliage, which is completely hidden with dense heads of flowers early in the Spring.

Sempervirens. Very dwarf and covThree Doz 100 ered with a sheet of white, a particularly fine rock plant. $\begin{array}{rrrr}\text { 1-year-old plants } & \ldots \ldots \ldots \ldots \ldots \ldots . \$ 1.85 & \$ 2.50 & \$ 15.00 \\ \text { 2-year-old clumps } \ldots \ldots \ldots \ldots \ldots & 1.20 & 3.50 & 25.00\end{array}$

Iittle Gem. Dwarf, pure white flowrs in June. Glaucous blue foli-

age. Splendid rock or edging

plant; perfectly hardy. 6 inches. $1.30 \quad 4.00 \quad 30.00$

INULA (Fleabane).

Golden Beauty. Free-flowering bor-

der plants with yell

$85-2.50-15.00$

INCARVILLEA (Hardy Gloxinia).

Large, rich rose, Begonia-like flowers with deep yellow throats, produced all through the Summer. A hardy perennial which succeeds well in borders and is equally valuable for greenhouse decoration. Height 18 inches.

Delavayi Rose-pink flowers poz 100 duced in large trusses $\ldots . .00 \quad \$ 3.00 \quad \$ 20.00$

IRISES (Species).

Some very interesting sorts are here listed and described; many of them splendid for naturalizing and large, permanent plantings.

Cristata (Evansia). A dainty native

Three Doz. 100 creeping species, only 3 inches in

height: flowers rich amethyst-

blue; a gem for the rock garden.

May .................\$0.85 \$2.75 \$18.00

Tectorum (Evansia). (Syn., Tom-

iolopha). A rare and beautiful

species from China and Japan,

with delicately crested flowers of

the most beautiful blue. This is

the "Roof Iris" of Japan, where

it is grown on the thatched roofs of the cottages. This Iris has proved hardy with us, but as the foliage is evergreen, it is bcnefited and will bloom inore profited and will bloom more pro-

covering of straw. One foot.

covering of straw. One foot.
June

\section{IRIS PUMILA.}

These beautiful little Irises do not grow over 4 inches high and bloom in April and tay. dering flower beds or planting in front of the tall Irises.

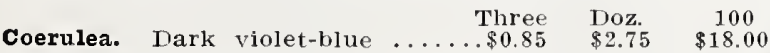

Excelsa. A splendid pale lemon-

yellow $\ldots \ldots \ldots \ldots \ldots \ldots \ldots \ldots \ldots \ldots \ldots .85 \quad 2.75 \quad 18.00$

Schneecuppe. A large, showy, pure

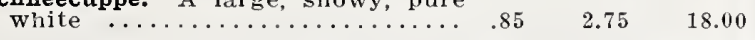

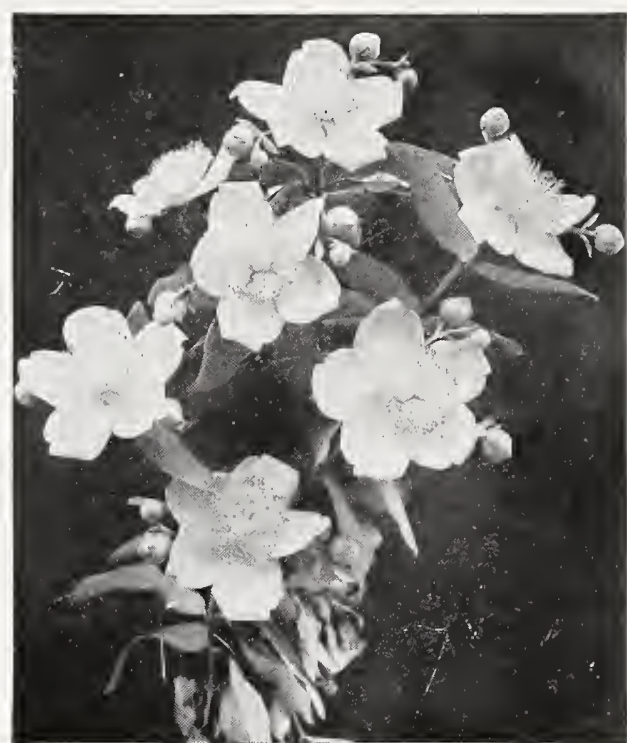

Hypericum Moserianum.

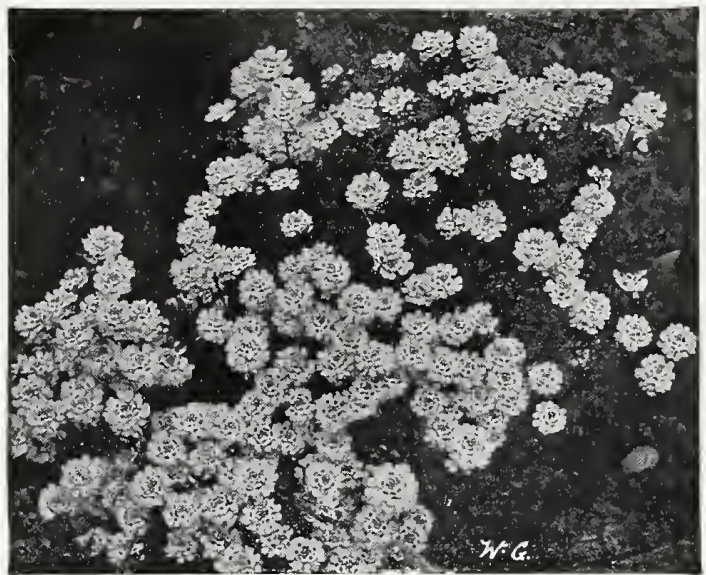

Iberis-Sempervirens.

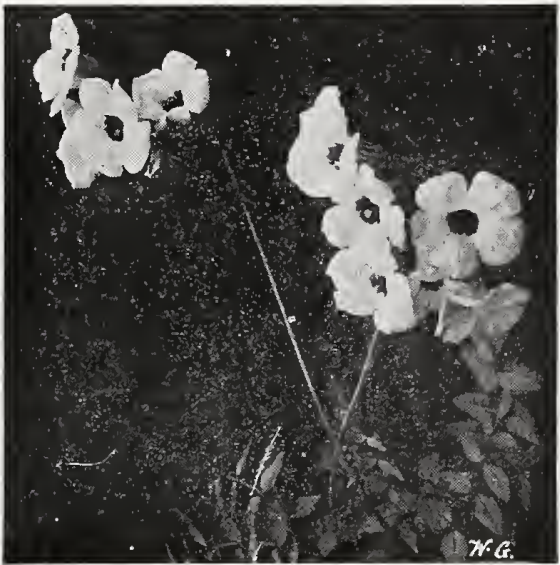

Incarvillea. 


\section{Merbaceous and Alpine Plants}

\section{ter.}

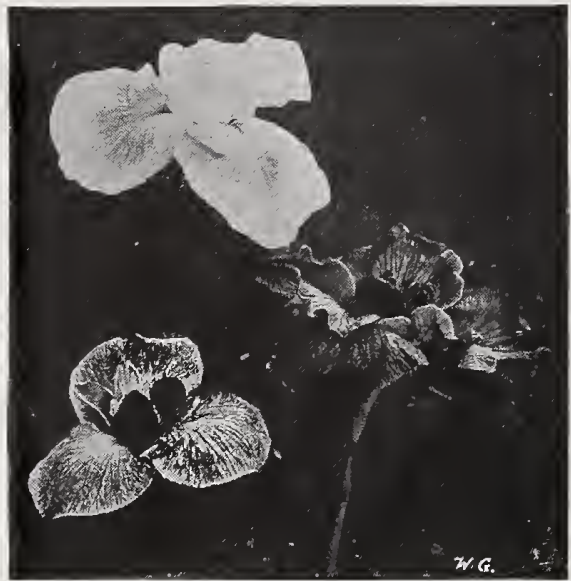

Iris Kaempferi-Japanese Iris.

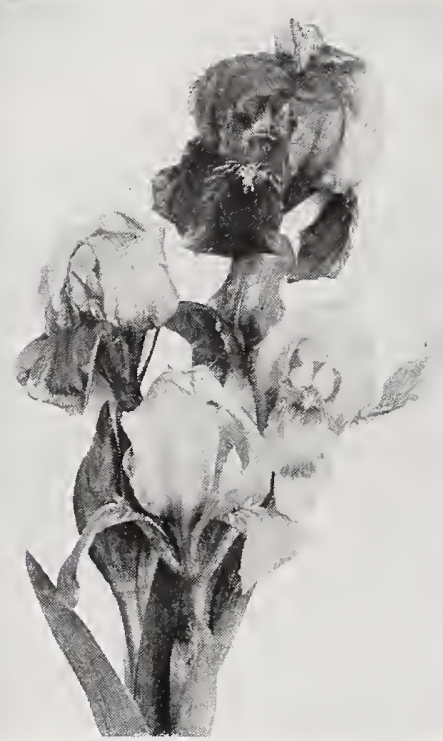

Iris Pumila, Varieties.

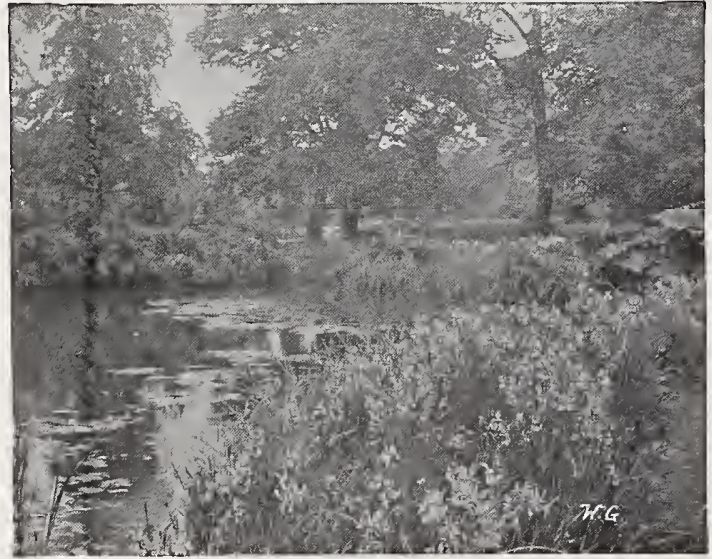

Siberian Irises.
IRIS KAEMPFERI (Japanese Iris).

The magnificent Iris Kaempferi belong to the Apogons, and a field of them in bloom is a most gorgeous sight Seeing them for the first time, one cannot withhold an exclamation of surprise, and having once seen can never forget their striking beauty.

Culture. The secret of success is to keep the ground well stirred, never allowing it to bake or become hard. Any good mellow clay loam will grow Japanese Irises to perfection, if well enriched. They like plenty of moisture during the growing season, but flooding with water is not a necessity, as many suppose. Water standing over the plants for a great length of time in Winter is fatal to them.

Time to Plant. Latter part of August to the beginning of October is the best time. Late plantings should be protected by a light covering of straw or leaves after the ground is permanently frozen, to prevent roots from being ground is permanenty frozen, to prevent roots from beins planting had best be deferred until Spring.

Three Doz.

100

Azure. Double. Immense flower, ex-

quisitely wavy; mauve-blue with

darker halo surrounding the yel-

low bloteh at base of petals $\ldots \ldots 1.35 \quad \$ 4.00 \quad \$ 30.00$

Dominator. Single. Rich indigo-blue

with narrow white stripes and

light center. One of the finest and

richest colors .............. $1.35 \quad 4.00 \quad 30.00$

Gold Bound. A fine double, pure

white, enriched by a creamy

glow from the gold banded center. $1.35 \quad 4.00 \quad 30.00$

Indo. Single. Broad, wavy petals of

great size, color dark rich blue,

only slightly veined. The yellow

central bloteh is unusually bright. $1.35 \quad 4.00 \quad 30.00$

Ia Favorite. Large, fine, white,

purple center ................. $1.35 \quad 4.00 \quad 30.00$

Mount Food. Double. Light blue shaded darker, bright orange cen-
ter ...................... $1.35 \quad 4.00 \quad 30.00$

Ondine. Single. White; flowers are of immense size; very free flower-

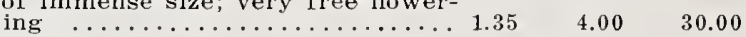

Purple and Gold. Enormous double flowers ten inches across; early and free blooming. Color rich violet-purple with white petaloids, tipped violet. The conspic-

uous golden throat extends out-

Pyramid. Double. Violet-purple

Double. Violet-purple
veined white in center of each

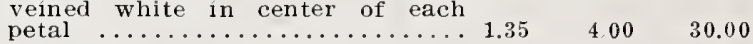

Shadow. Single. Self color, reddish
purple $\ldots \ldots \ldots \ldots \ldots \ldots \ldots$

Mixed Colors. Both single and double varieties. Splendid mixture $\ldots \ldots \ldots \ldots \ldots \ldots \ldots \ldots \ldots \ldots \ldots 1.00 \quad 3.00 \quad 20.00$

\section{IRIS SIBIRICA (Siberian Iris).}

Vigorous, free-flowering varieties of the easiest culture, fine for the flower border, for naturalizing and for waterside planting.

snow Queen. An exquisite Three Doz. 100 hardy Iris: the flowers are of snowy whiteness, large and well formed, produced in great abundance; foliage light and graceful. A gem for flower border or waterA gem for high ....\$1.00

Superba. Large, violet-blue flowers handsome foliage. Fine border plant and a grand subject for planting near water, where it blooms profusely ............ 


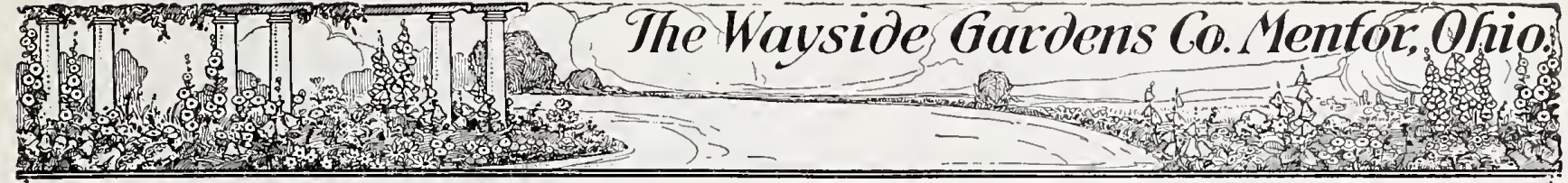

IRIS GERMANICA (German or Flag Iris).

The Iris is one of the finest, if not the finest, of our hardy plants. Not particular as to soil or location, but asking only that the sun shine on it. It throws up spikes of bloom that are marvelous in their delicacy of structure and the colorings which are exquisitely dainty are wonderful in their blendings and variety.

They are very effective planted in groups and if used for borders are particularly desirable in that the foliage remains fresh and upright after the blossom stalks are removed.

Plant in late August or early September preferably. spring will do also.

The roots offered in this list are from plants transplanted a year ago and are of a size large enough to bloom nex Spring. The collection is up to date and consists of the best and newest standard varieties.

Twenty-five roots at 100 rate, 250 roots of a kind at 1000 Tate We guarantee the usual Wayside Gardens quality. The letter "s" refers to the standards or upright petals "F" the falls or drooping petals.

\section{Choice New Introductions}

Cecil Minturn (New). Soft cattleyarose. A beautiful Hower with broad petals, gracefully waved and broad petals, gracerul wist irises crinkled; one of the finest irises Hach, $\$ 2.00$

Ient. A. Williamson. Rated in 1922 by the American Iris Society as the finest Iris in the world. S Campanula blue-violet: F. rich Campanula blue-violet; F. rich Very tall and distinct ......... Each, $\$ 1.50$

Iord of June. S. lavender-blue; $F$ rich violet-purple. A magnificent variety of gigantic size ................. 1.25

Mme. Chobant (Denis, 1916). 36 inches. A clover-scented Plicata type. Prussian-red with light dony ground. One of the most beautiful of all Irjs .......... Each, $\$ 1.50$

Queen Caterina (Sturt). A midseason variety of a beautiful clear orchid-purple veined with brilliant gold; the whole being further enhanced with a bright orange

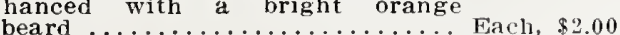

skelinah (Sturt). A delightful shade of pale yellow shading to amber in the throat, with a lemon colored beard. This is a true yellow Pallida. and the first of the type handsome variety ........... Each, $\$ 1.50$

\section{General Iist of German Iris}

Varieties marked with (*) have distinctive points of real merit, and are in our opinion the best of the moderate priced varieties.

Alcazar (Vilmorin, 1910). Certificate, N. H. F., 1909; F. C. C. R. F. S. 1916. S. light bluish violet; F deep purple with bronze-veined throat. Striking flower ....... \$1.20 \$3.50 \$25.00

*Archeveque (Vilmorin, 1911). Certificate R. H. S., 1916 . S deep purple-violet; $F$. deep velvety violet.

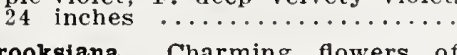

Brooksiana. Charming flowers of rose-lilac, without veining. Beau tiful in masses .................... $85 \quad 2.50 \quad 15.00$

Candelabre $\ldots \ldots \ldots \ldots \ldots \ldots \ldots \ldots \ldots .1 .003 .00 \quad 20.00$

*Caterina (Foster, 1909). A. M., R. H. S., 1916 . Lavender-blue and lilac of same coloring as Pallida Dalmatica, but taller, with more graceful stem. A beautiful flower, but a poor grower in cold sections. 48 inches ......................

Caprice (Vilmorin, 1904). Certificate deeper rosy

handsome. 24 inches .......... 1.003 .00

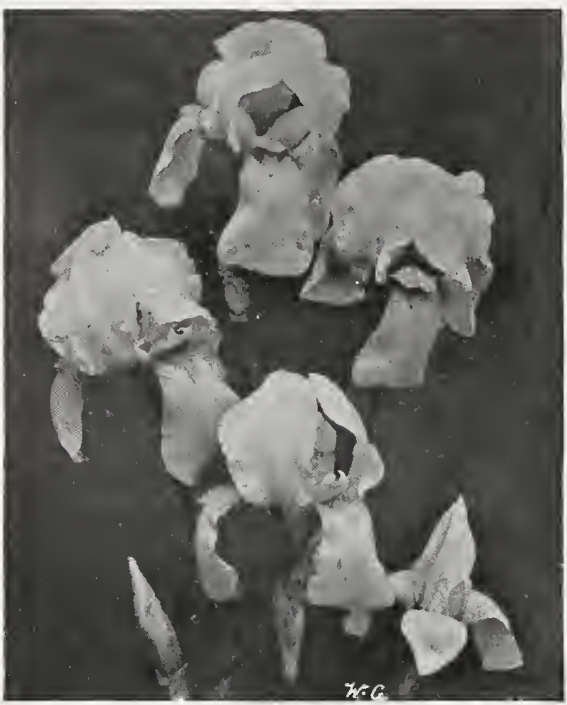

German Iris, Lord of June.

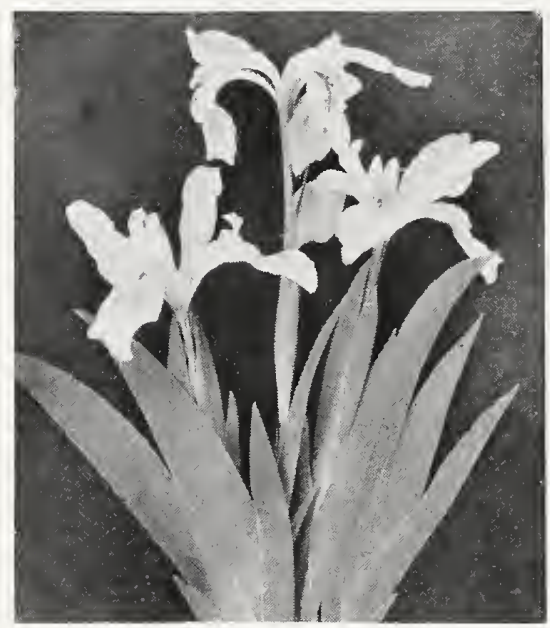

Iris Tectorum.

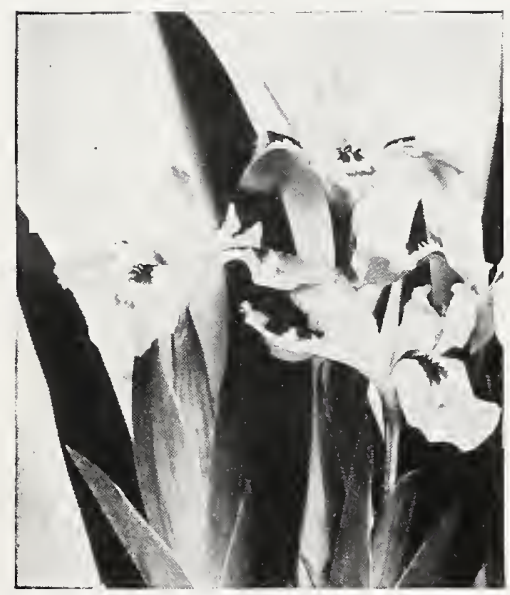

Iris Cristata. 


\section{Terbaceous and Alpine Plants \\ (2)}

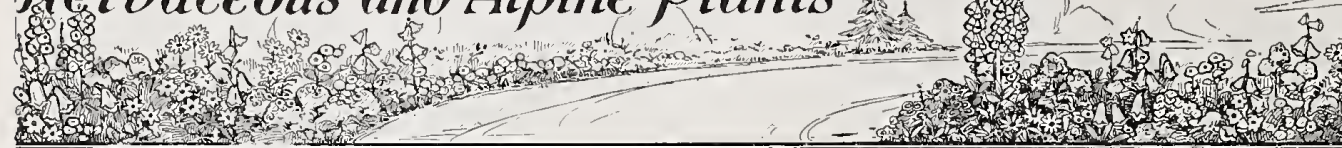

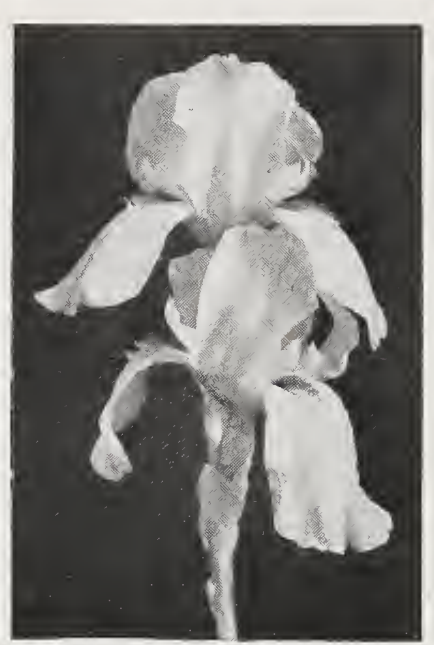

Iris, Helga.

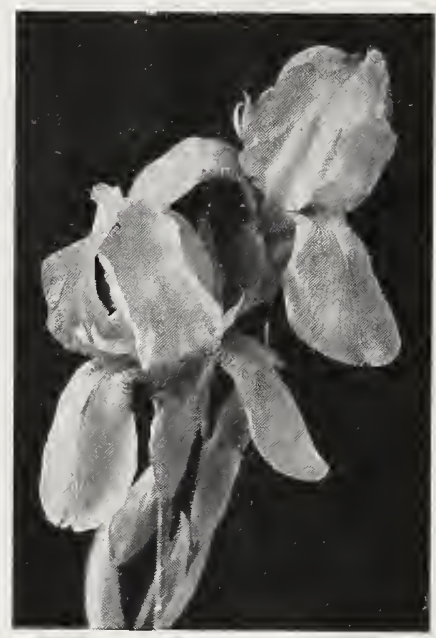

Iris Monsignor.

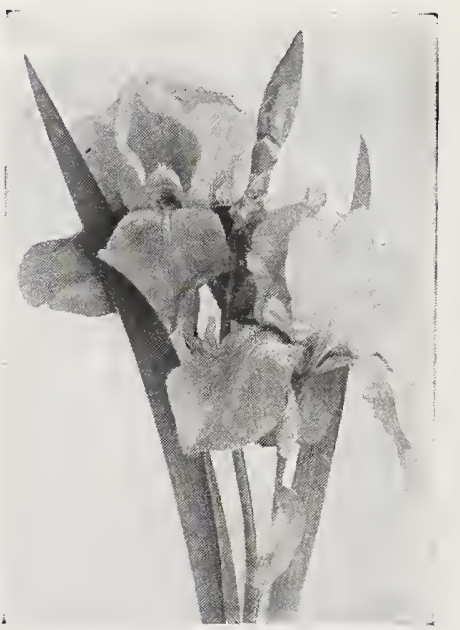

Iris, Oriflamme.

\section{IRIS GERMANICA-Continued.}

Three Doz.

100

*Cherubin. This may be describea as a pale edition of Her Majesty. The standards are very pale lilac the falls are pale lilac thinly veined with purple . W.........

Fairy (Kennicott, 1905). White, delblue. The tallest standard variety giving a white effect. Not new but not known or appreciated as it should be 40 inches ........

Helga. Lemon-yellow with pearl shading. Huge flower .......... Ingeborg (Goos \& Koenemann, 1908). Ingeborg (Goos \& Koenemann, 1908 ) A. M., R. H. S., 1916. The only cultivation. Strong grower and free bloomer …… Round standards of pale

* Isoline. Round standards of pale
pinkish buff, strongly flushed mauve; the sharply reflexed falls are chinese violet with russet tints at the sides; bewildering shades but most attractive .....

Juniata. A stately plant with gracefully carried mauve to manganese fully carried mauve to manganese

* Jeanne a'Arc (Verdier, 1907). $\quad$ s. very large and ruffled, somewhat spreading, white, delicately penciled lilac; F. white edged lilac at base. The standards being somewhat loosely held, flutter in the breeze in a truly delightful man-

ner of iris (Goos \& Koenema..... King of Iris 1907). A. M., R. H. S., 1916. S clear lemon-yellow: $F$. rich maroon, bordered yellow. Brilliant colors. Large flowers. Very fine.

zorely. Light yeliow, blue falls bordered cream $\ldots \ldots \ldots \ldots \ldots \ldots$.

* Teonidas. Standards clear mauve; falls rosy mauve. Big, of fine form, handsome $190 . \cdots$. . . light mauve with bronze sheen; $F$. soft red-violet, very large flower ....

Madame Chereau. White elegantiy frilled with a wide border of clear frilled with a wide border of clear

Mandraliscae. Rich lavender-purple tall, large and handsome; very

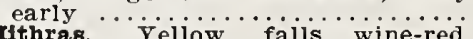

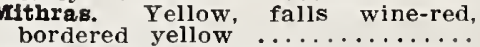

Monsignor. It possesses a distinctive and pleasing shape, rich color ing and pleasing shape, rich coloring and a dark outline to the segments for emphasis. Standards violet; falls heavily veined purple,

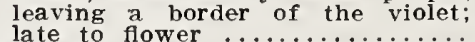

late to flower .............. der-pink Gray. A delcate lavender-pink that appears pinker in the shadow, a variety of rather

mdanight. A rich deep purple, the finest in this color; a flne cut

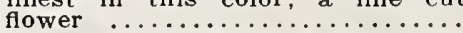

Tibelungen (Goos \& Koenemann, $1910)$ S. fawn and yellow: $\mathrm{F}$. 1910). S. fawn and yellow; F. violet-purple on bronze. Very
large flowers; strong, vigorous

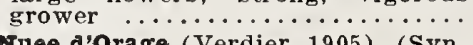

* ruee d'Orage (Verdier, 1905). (Syn., Storm Cloud). Cert., N. H. F., 1905. s. slaty oronze and purOrlfiamme (Vilmorin, 1904). Cert., 1916. S."light blue; F. rich violetpurple. Immense, handsome flowers of Ames form. 30 inches .. 1.20

* Pallida Dalmatica (True). A. M., R. H. S., 1916. S. lavender; F. clear, deep lavender. A variety of this name is mentioned in Gerarde's Herbal in 1597, and it has been grown in this country more than one hundred years and is often seen in old gardens, but the true variety is still scarce. Unsurpassed in its class. 40 inches. 1.00 


\section{ORDER SHELT}

\section{The Wayside Gardens Company Stop 67 \\ Mentor, Ohio}

Ship to (Name)

Street or
R. F. D. No.

Town or

City

County

Charge to.
Date

Ship by (State whether by Freight, Express or Mall.) Money Order Enclosed for $\$$

Cheque Enclosed for a Address

May we substitute an equally good variety if any of the kinds ordered are sold out No___ Yes

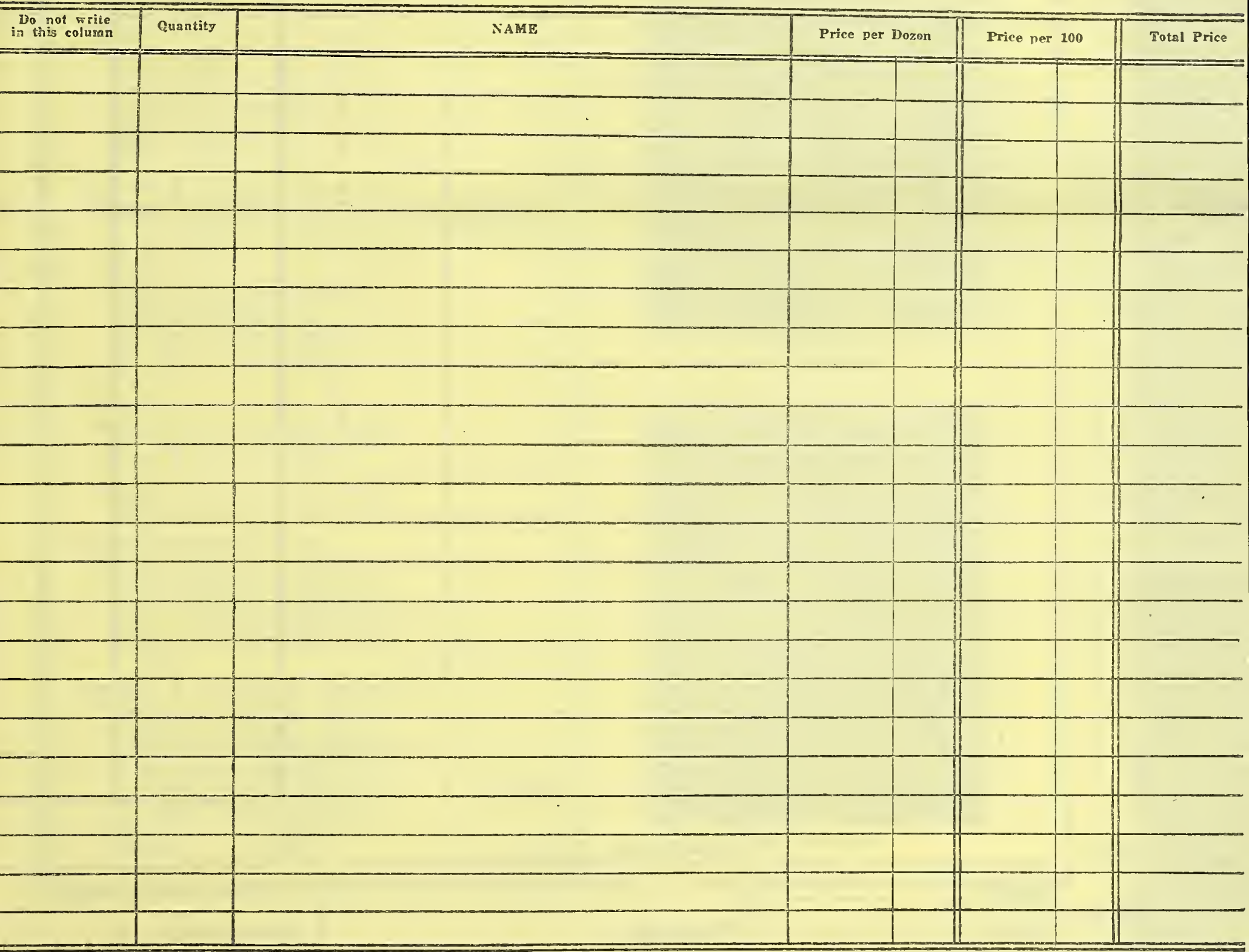




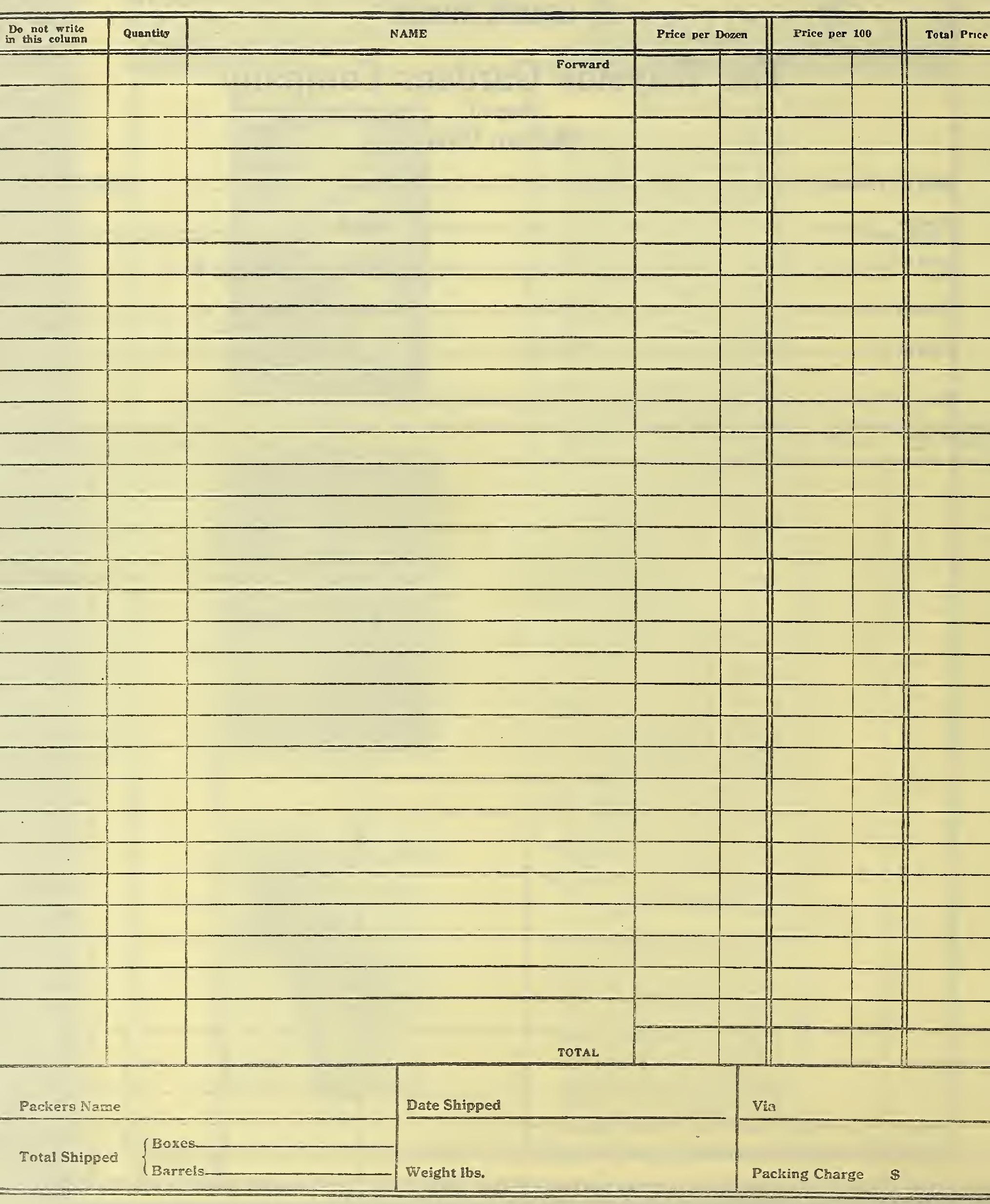




\section{Terbaceous and Alpine Plants}

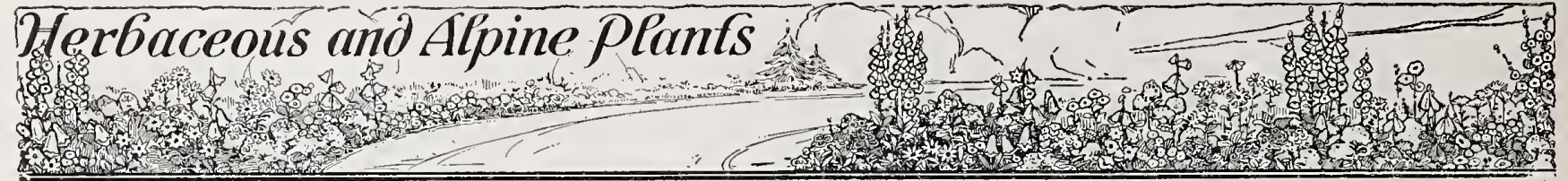

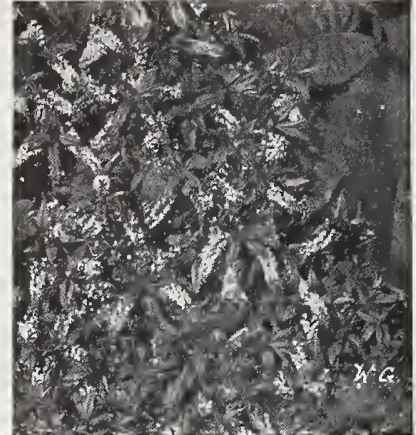

Lysimachia Clethroides.

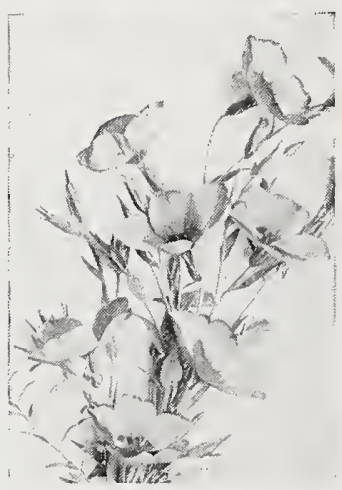

Linum Perenne.

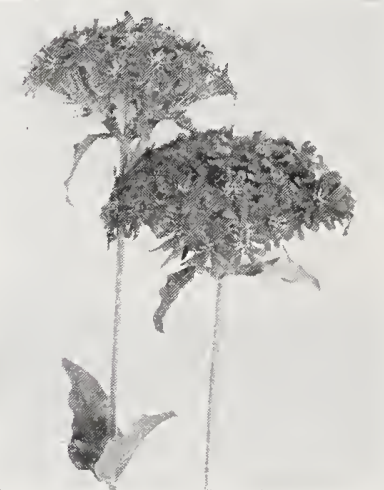

Lychnis Chalcedonica.

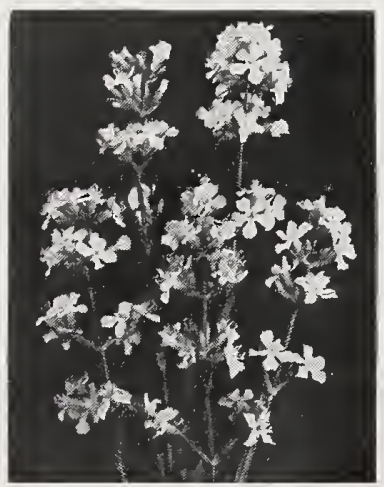

Lychnis Haageana.

LILY-OF-THE-VALLEY (See Convallaria).

LINARIA (Toad Flax). Three Doz. 100

Dalmatica. Fine for borders or per-

ennial garden. Glaucous blue fo-

liage and spikes of golden yellow

blossoms; miniature Snapdragon.
Loves a sunny spot in wcll drained

soil $\ldots \ldots \ldots \ldots \ldots \ldots \ldots \ldots \ldots \ldots \ldots \ldots \$ 0.85 \quad \$ 2.50 \quad \$ 15.00$

LINUM (Flax).

A desirable plant for the horder or rockery, growing " feet high, with light, graceful foliage and large flowers all summer.

Flavum, Fine variety with trans parent, yellow blossoms ...... \$0.85 $\$ 2.50 \quad \$ 15.00$

Narbonnense. Folms a spreading clump of attractive foliage with a with white eye. Very handsome with white eye. Very handsome
for the rockery ................. $1.00 \quad 3.00$

Perenne. Very attractive, both in foliage and bloom. Flowers beautiful pale blue on slender, grace-
ful stems $\ldots \ldots \ldots \ldots \ldots \ldots \ldots \ldots \ldots$

Perenne. White ............ .85 $2.50 \quad 15.00$

LOBELIA (Indian Paintbrush).

Handsome border plants, thriving in any ordinary garden soil, but preferring a moist, deep loam. Season August till late september.

Cardinalis (Cardinal Flower). Rich, Doz. 100

Cardinalis (Cardinal Flower). Rich, plants, often producing ten to

eighteen spikes. 24 to 30 inches

long .................. \$0.85 \$2.75 \$18.00

LYCHNIS (Campion).

A fine old-fashioned flower, bearing large heads of brilliantly colored flowers, that liven up the border during Summer and early Autumn.

Alpina. Dwarf, rose-pink ....... Thrfe Doz. $\quad \begin{array}{cc}100 \\ \$ 100\end{array}$

Chalcedonica. Heads of vivid scarlet flowers, blooming a long time. One of the brightest plants in the hardy border. 3 feet .......... $85 \quad 2.50 \quad 15.00$

Viscaria splendens. Brilliant red.. $.85 \quad 2.50 \quad 15.00$

Haageana. 1 foot. June to August. Very showy; producing orangered, scarlet or crimson flowers nearly 2 inches across ......... 1.00

Viscaria flore pleno. A fine double variety; fine for cutting ...... 1.00

YCORIS (Golden Spider Lily).

Squamigera (Amaryllis Halli). The attractive green foliage appears in early spring, ripens and dies down in July. Shortly after, the flower stems bearing delicate lilacpink flowers make their appear-

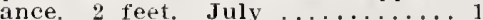

LYTHRUM (Purple Loosestrife).

Superbum roseum. Very showy splendid for banks of streams and ponds $\ldots \ldots \ldots \ldots \ldots \ldots \ldots \ldots \ldots \ldots \ldots .85 \quad 2.50 \quad 18.00$

LYSIMACHIA (Loosestrife)

Clethroides. Tong, recurved spikes of pure white flowers, from July to September. A desirable variety. 2 feet ................ $1.00 \quad 3.00 \quad 20.00$

Nummularia (Creeping Jenny or Moneywort). Valuable for planting under trees or shrubs where glass will not grow ...........

Fortunei. A neat variety growing about 18 inches high, with dense, upright spikes of white flowers in August ............... 1.00 


\section{Terbaceous and Alpine Plants}

\section{Solo}

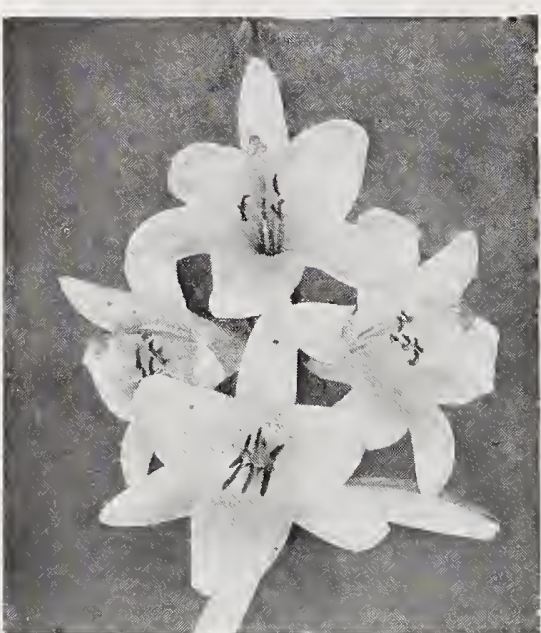

Lilium Candidum.

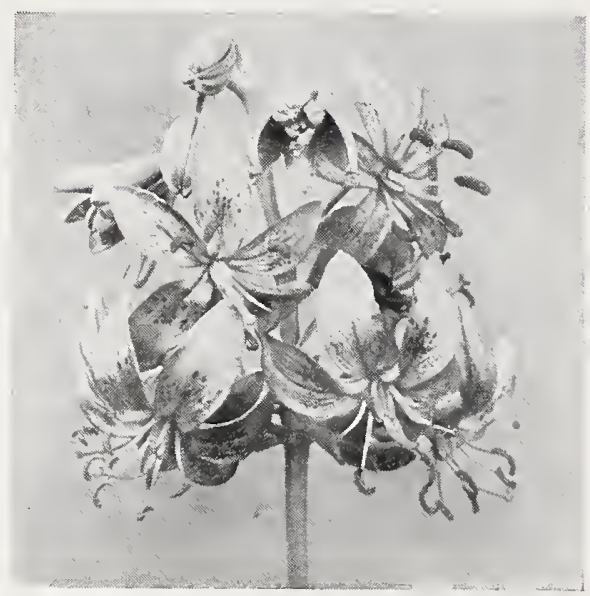

Lilium Hansoni.

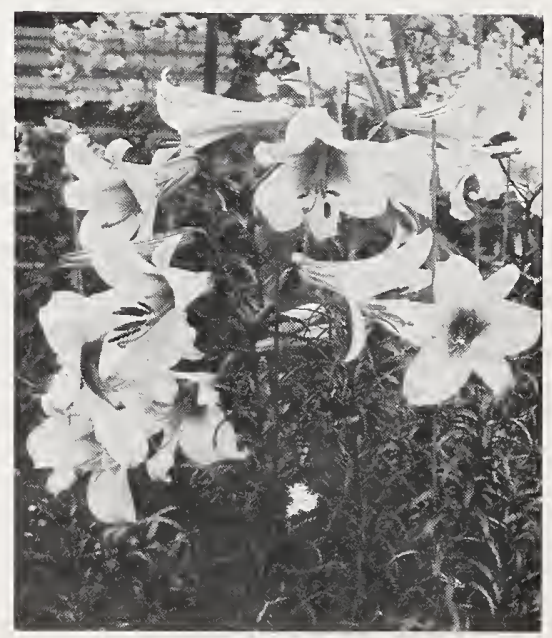

Regal Lily.

\section{IIIIFs-Continued.}

Each Doz. $\quad 100$

Colchicum (Scovitzianum), A beautiful lemon-yellow Lily, produced in pyramidal clusters of drooping,

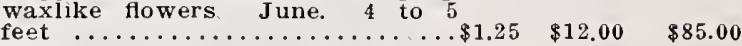

*Daruricum. This beautiful Lily comes from the home of $L$. tenuifolium in Siberia. It resembles a native Philadelphicum. It is of easy culture, grows two or three to five upright scarlet flowers,

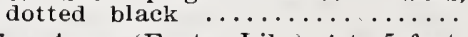

Giganteum (Easter Lily). 4 to 5 feet. July and August. Most majestic of all the Lilies. White, fragrant, funnel-shaped flowers .........

Eansoni. Most desirable; not particular in its cultural requirements and extremely handsome in flower, does well in light loam. Plant among shrubs and low plants to protect young shoots, this being protect young shoots, this being one of the earliest Lilies to appear in the Spring. The stem reaches a height of 4 to 5 feet, carrying ly reflexed, the petals being of a bright orange spotted more or less with brown, of a waxy texture. Admirable for pot culture. June

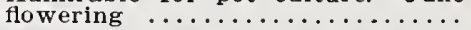

* Henryi. A new Japanese Lily that has made a sensation in Europe. It has the same form and appearance as the Speciosum varieties, but the flowers are bright orangeyellow. We grow this variety now ourselves from seed. They are as hardy as a tree. Shipment Octo-

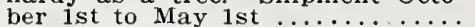

Krameri. Unique for its color and grows from 2 to 4 feet high. The funnel-shaped finely formed flowers are 6 inches or more in length and as much across, of a beautiful clear pink color, often shaded blush $\ldots \ldots \ldots \ldots \ldots \ldots \ldots \ldots$

*Martagon (Dalmaticum, Turk's Cap Lily). A handsome Lily, bearing clusters of purple, waxlike flow ers. Thrives best in partial shade June. 5 feet $\ldots \ldots \ldots \ldots \ldots \ldots \ldots \ldots$

Pardalinum (Leopard Lily). Flowers reflexed, bright yellow at base spotted brownish purple, remainJuly and August ............

Philadelphicum. A handsome native Lily with yellow, cup-shaped flowers, spotted maroon and shaded orange at ends of petals Good orange at ends of petals
for naturalizing. July. 3 feet. for naturalizing. July. 3 feet.

Pomponicum. A brilliant red Turk's Cap Lily. Much like Chalcedonicum, but with the heads of flowers rather more loosely arranged. June 3 to 4 feet ............

Pyrenaicum (Yellow Turk's Cap Lily). A Lily of easy cultivation with many small, yellow flowers, dotted brown Reflexed petals.

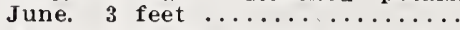

* Regale or myriophyllum (The Regal Lily). It is absolutely hardy, and is excellent for forcing. It has been predicted that this will become the Easter Lily of the future, and being so hardy, may be srown at home. The flowers are white, slightly suffused with pink, with a beautiful shade of canaryyellow at the center, and extending part way up the trumpet. It is delightfully perfumed, reminding one of the Jasmine, and lacking one of the Jasmine, and lacking the heavy, oppressive odor of
most Lilies. Blooms out-of-doors early in July.

Flowering size. Strong bulbs ... Lazge size .................
$2.75 \quad 18.00$

$50 \quad 400$

30.00
50.00

50.00

30.00

60.00 


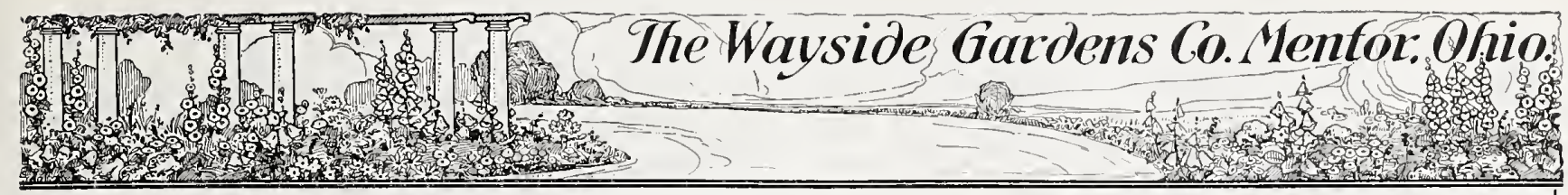

IIIIP8-Continued.

Rubellum. Beautiful small Lily. The color varies from a deep rosepink to almost white, with yellow anthers; very fragrant, small funnel-shaped flowers; grows $11 / 2$ feet high. It does best in light soil . $\$ 0.50$

$\$ 4.00$

$\$ 30.00$

Speciosum album. The Speciosum or Lancifolium are the most important of all the Japanese Lilies, always satisfactory. The variety here offered has large, white flowers of great substance, with a greenish band running through the greenish band running

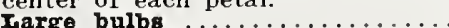

rargo bulbs $\ldots \ldots \ldots \ldots \ldots \ldots \ldots$

spectosum magnificum. Magnificent large flowers of rich deep red. rammoth bulb.

speciosum melpomene. A darker shade of red and crimson markings than the preceding.

rarge bulbs

Mammoth buibs $\ldots \ldots \ldots \ldots \ldots \ldots \ldots$

*Superbum. 3 to 4 feet. July. Flowers bright reddish orange, conspicuously spotted..$\ldots \ldots \ldots \ldots$

*Tenafolium (Siberian Coral Lily). A most delicate and charming species. Growing from 1 to 2 feet high, it bears often from 1 to 12 or more nodding rich scarlet or more nodding rich scarlet

*Tenulfollum "Golden Gleam." Similar in form to the preceding. Flowers are a delicate apricot shade $\ldots \ldots \ldots \ldots \ldots \ldots \ldots \ldots$.

*Testaceum (Excelsum or Nankeen Lily). This is one of the finest Lily). This is one of the finest of all to describe, being a shading cult to describe, being a shading of dull apricot with orange-yellow anthers. A most graceful Lily and a good companion to $\mathrm{L}$. candidum. June-July. 5 feet. Extra large

*Thunbergtanum (elegans) vangulnoum. Dark crimson. The Thunbergianums are all of the easiest culture and bloom in June .....

* Tigrinam flore pleno (The double Tiger Lily). The only Double Tiger Lily worth growing .......

* Tigrinum implex (The well known Single Tiger Iily). Of easiest culture and worthy of general planting on account of stateliness.

wallacel. A handsome Lily of a beautiful shade of the warmest apricot with rosy shading. August. apricot with rosy shading. August.

Washingtonlanum. A beautiful Lily from California, with large, reflexed flowers, varying in color from light to a rich wine color, slightly spotted deeper. This variety requires a moist but well drained situation. June-July. 3 to 5 feet. Extra large bulbs.

wuimottiae. One of the flnest garden Lilies, although little known. Lovely in its graceful habit, slender foliage and heads of vivid orange-red flowers and kindly in its vigorous and thrifty constitution. July-August. 3 to 4 feet .. 1.00

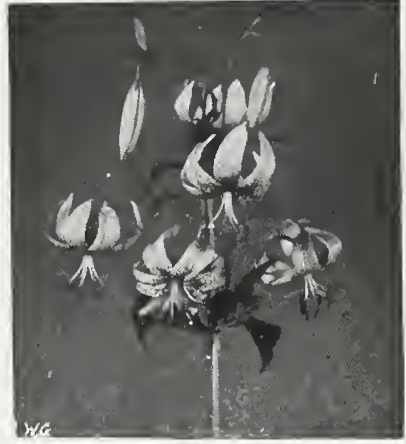

Lilium Superbum

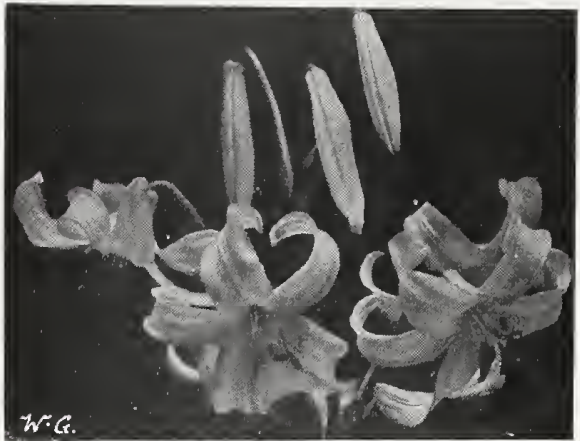

Lilium Testaceum.

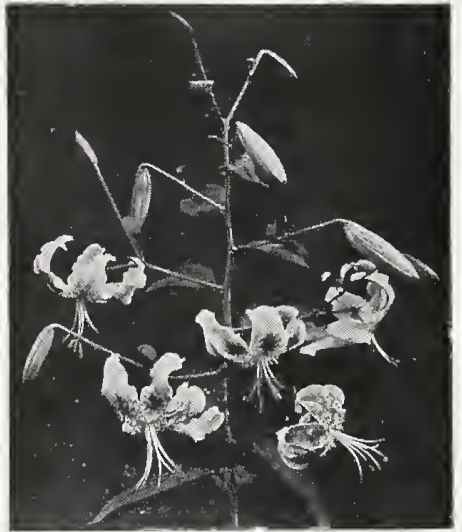

Lilium Speciosum.

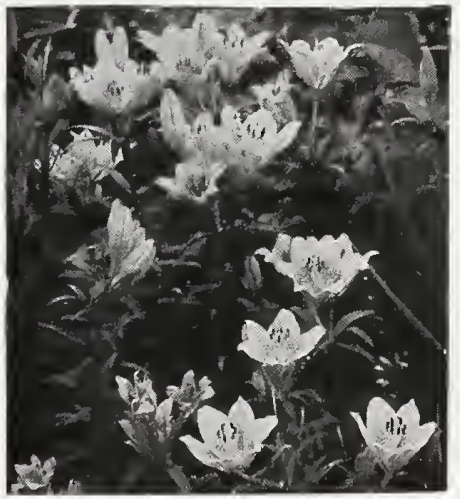

Lilium Davuricum. 


\section{Herbaceous and Alpine Plants}

\section{8.}

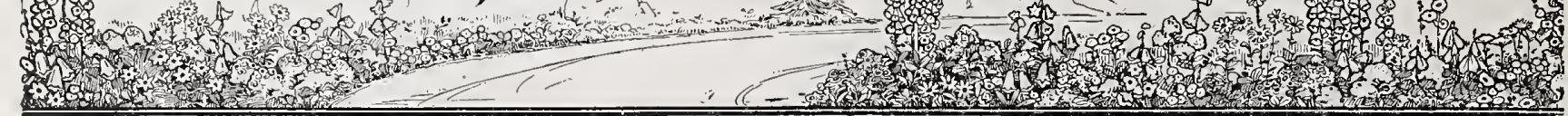

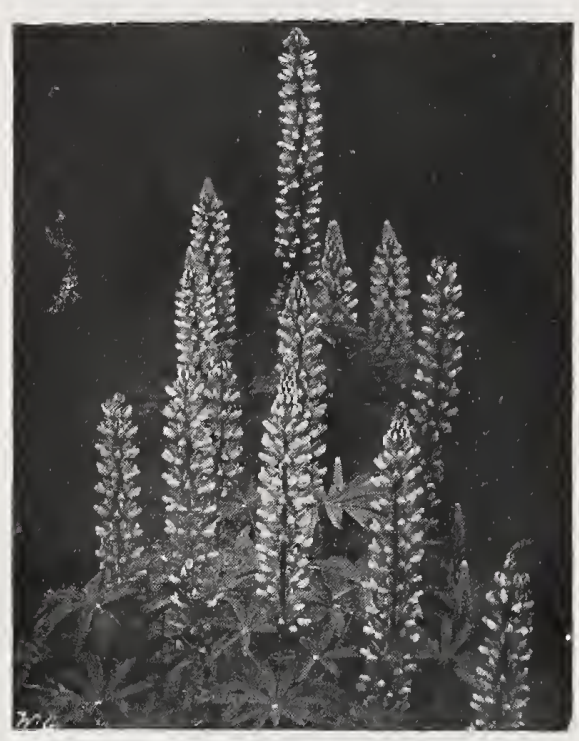

Lupinus.

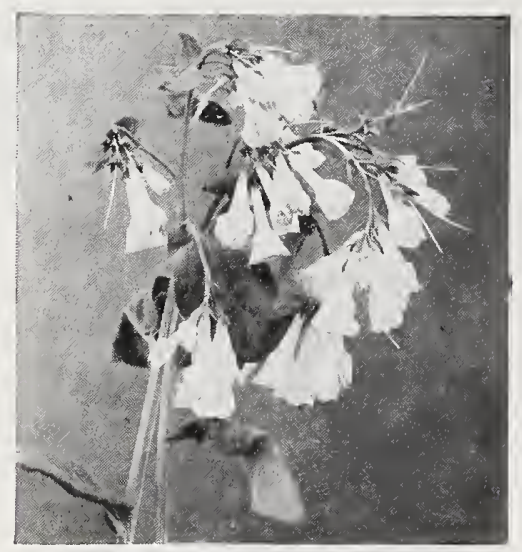

Mertensia Virginica.

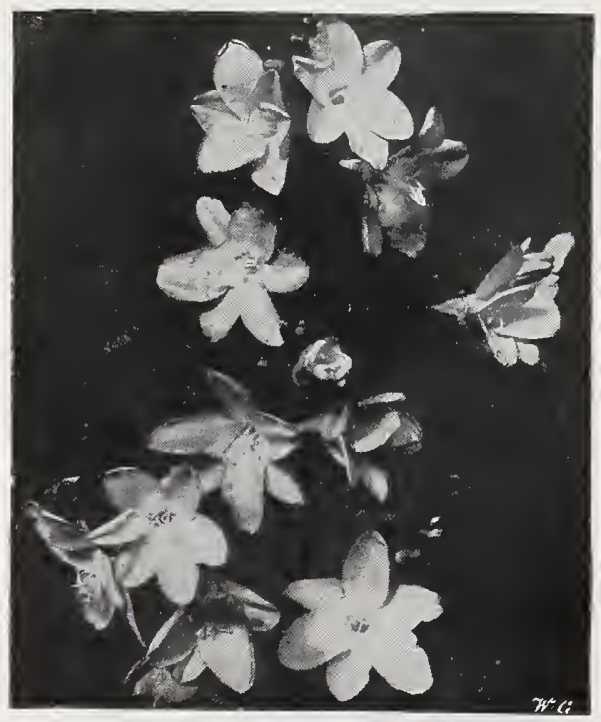

Montbretia.

\section{LUPINUS (Lupines).}

The Lupines produce beautiful long spikes of pea-shaped flowers a foot long on stems three feet high. They are perfectly hardy but cannot endure drought, and must be planted in well prepared garden soil and kept watered in dry weather

Wayside Gardens New Sweet-Scented Three Doz 100 Fybrids (Polyphyllus). A wonderful new strain that may be classed among the most beautiful of all hardy flowers. Colors are both rich and delicate in shades of blue, mauve, pink, etc., and the flowers are borne in long spikes that for size and beauty rival giant Snapdragons. The added novelty of being sweet scented, makes these one of the best garden plants we have ever distribPolyphyllus (Hardy Lupin). Clear

blue. 3 to 4 feet. June-September. $1.00 \quad 3.00 \quad 20.00$ Polyphyllus albus. A white variety. $1.00 \quad 3.00 \quad 20.00$ Polyphyllus roseus. A splendid tifully shaded rose Polyphyllus, Sunshine. Pure yellow $\ldots \ldots \ldots \ldots \ldots \ldots \ldots \ldots \ldots \ldots . \ldots \ldots 1.35 \quad 4.00 \quad 30.00$ Polyphyllus, Rosy Morm, Deep pink. 2.75 $8.00 \quad 60.00$ Polyphyllus, Ruby King. Ruby-red. $1.35 \quad 4.00 \quad 30.00$ Polyphyllus, Moerhelmi. Pink ... $1.00 \quad 3.00 \quad 20.00$

MATRICARIA (See Feverfew: Mayweed).

\section{MAZUS.}

Rugosus. A dwarf and interesting Alpine plant from the Himalayan Mountains, covered in early Spring with dainty lilac and white flow ers 4 inches ...................

MERTENSIA (Blue Bells)

Virginica. An early Spring-flowering plant, growing about 1 to $1 \frac{1 / 2}{2}$ feet high with drooping panicles of handsome light blue flowers, fading to clear pink; one of the most interesting of our native Spring fowers............. $85 \quad 2.50 \quad 15.00$

MONARDA OR BERGAMOT (Oswego Tea).

Showy plants growing from 2 to 3 feet high, succeeding in any soil or position, with aromatic foliage, and pro ducing their bright flowers during July and August

Didzma, Cambridge Scarlet. Three Doz. 100 liant crimson-scarlet $\ldots \ldots \ldots \ldots \ldots \$ 0.85 \quad \$ 2.50 \$ 15.00$

\section{MONTBRETIA (Tritonia).}

One of the brightest of our Summer-flowering bulbs, and should be set during April or May. They should be protected during the Winter with a heavy covering of leaves or litter.

Three Doz 100 verse of petals flowers petals orange, large

King Ydmund. A robust grower $\$ 1.50 \$ 10.00$ with large, open flowers, rich yel low, with a carmine-blotched

Iord Nelson. A handsome darkstemmed varlety, flowers of great substance, of a rjch deep orange outside vermilion .............

Prometheus. Large, rich orange. marked with deep red at center.

Rheingold. A beautiful clear golden yellow; large spike and ver. vigorous grower ..............

Speclosa. Richest of all in color flowers large of intense scarlet

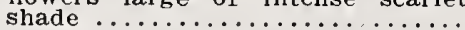

MITELLA (Bishop's Cap).

Diphylla. A gem for a shady position. Feathery spikes of creamy white flowers. I2 to 18 inches. May and June ............. $1.00 \quad 3.00$ 


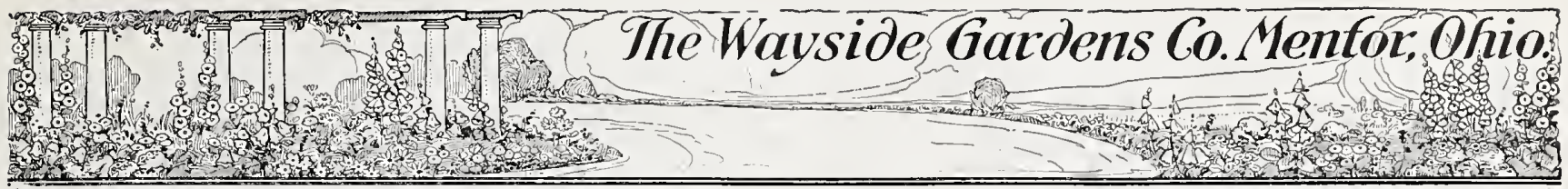

MYOSOTIS (Forget-me-not).

Alpestris (Alpine Forget-me-not).

Splendid for naturalizing on edge

of ponds and streams; also for

beds, borders and rockeries $\ldots . \$ 0.85 \quad \$ 2.50 \quad \$ 15.00$

Palustris semperflorens. Large, rich

blue flowers with yellow eye; a

charming plant for damp places

and a more profuse bloomer than

the type .................... $\quad 85 \quad 2.50$

NEPETA (Ground Ivy; Catnip; Catmint).

Mussini. An excellent plant for

any position, but especially usefu

in the rock garden. Or dware

of bloom of a beautiful shade of

lavender. 1 to $11 / 2$ feet .........

$.85 \quad 2.50$

15.00

NIEREMBERGIA (Cup Flower)

Rivularis. A charming dwarf creeping Alpine plant, bearing large creamy white, cup-shaped flowers

desirable plants for the rockery. $1.00 \quad 3.00 \quad 20.00$

OENOTHERA (Evening Primrose).

Elegant for a sunny position in the border or on the rockery, blooming all summer.

Three Doz. - 100

Fraseri. 1 foot. June to October.

Flowers large, pale yellow .... $\$ 0.85 \quad \$ 2.50 \quad \$ 18.00$

Fruticosa major. 2 feet. June to

September. A strong growing

specimen: flowers deep yellow, in

profusion $\ldots$.

Youngi. 2 feet. June to August. A

strong, stocky, large-leaved plant

with firm, shiny foliage: numer-

Missourionsis. 10 inches. June to

August. A low species with pros-

trate, ascending branches; profuse

bloomer. Solitary flowers, often
5 inches across. Good for rock

garden or border white.............

ONOSMA (Golden Drop).

Stellulatum. A rare and beautiful plant for the rock garden. It forms an evergreen tuft of leaves and bears during May and June drooping clusters of amber colored, drop-shaped blossoms, deliciously almond scented. It drained position. 9 to 12 inches. $1.20 \quad 3.50 \quad 25.00$

PACHYSANDRA (Japanese Spurge).

Terminalis. A trailing plant 6 to 8 inches high, forming broad mats of bright glossy green foliage and small spikes of flowers during May and June. A ground cover, which will grow in all shady sitwillions and the only plant which better and hardier than Ivy or any other shade-loving, dwarf plant.

$\begin{array}{lccc} & & & \\ \text { Strong, 1-year, field-grown plants. } \$ 1.75 & \$ 100 & 1000\end{array}$

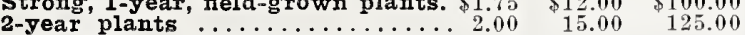

PARDANTHUS (Blackberry Lily).

Very pretty perennial with lily-like flowers of a very handsome appearance. Requires a rich soil and a sheltered situation in Winter.

Three Doz. $\quad 100$ spotted with purple-brown

spotted with purple-brown. 18
inches $\ldots \ldots \ldots \ldots \ldots \ldots \ldots \ldots \ldots \ldots$

PAPAVER NUDICAULE (Iceland Poppy).

The plant is of neat habit, forming a tuft of bright green, fernlike foliage, from which spring throughout the entire season, a profusion of slender, leafless stems 1 foot high, each graced with charming cup-shaped flowers.

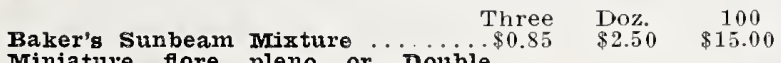

Miniature flore pleno or Double
Nudicaule $\ldots \ldots \ldots \ldots \ldots \ldots \ldots \ldots$

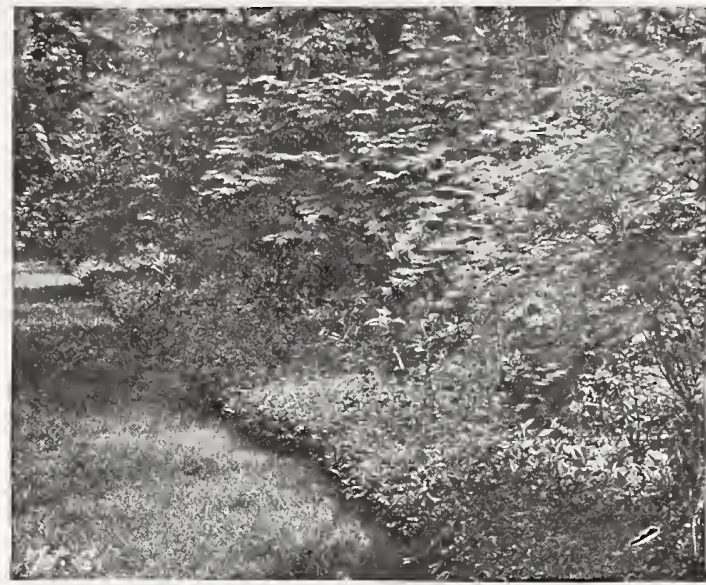

Pachysandra Terminalis.

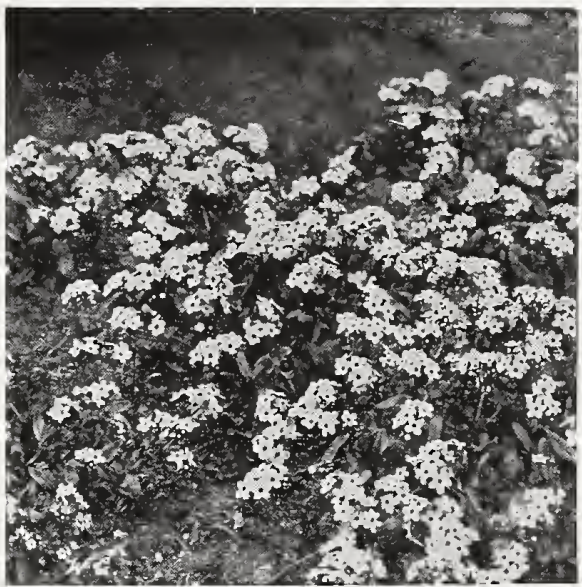

Myosotis Palustris.

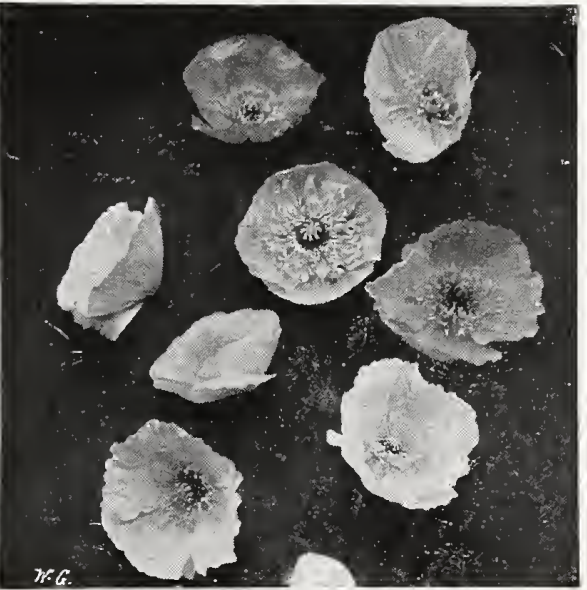

Papaver Nudicaule. 


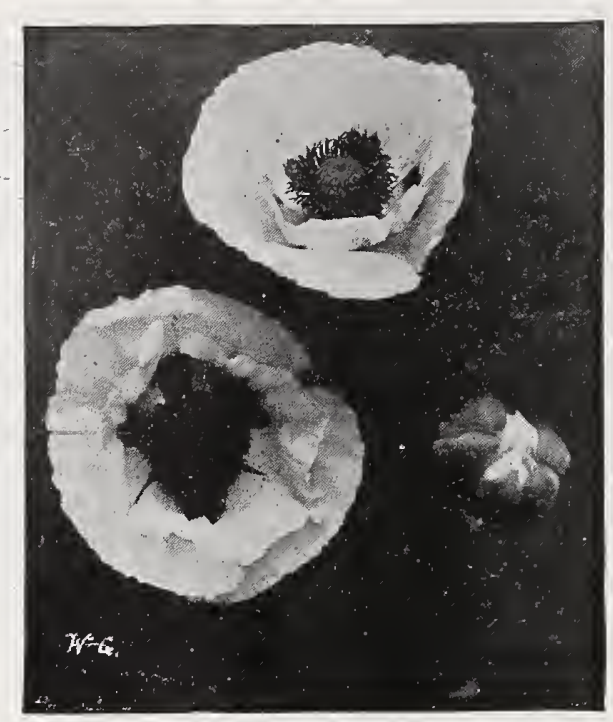

Papaver, Mrs. Perry.

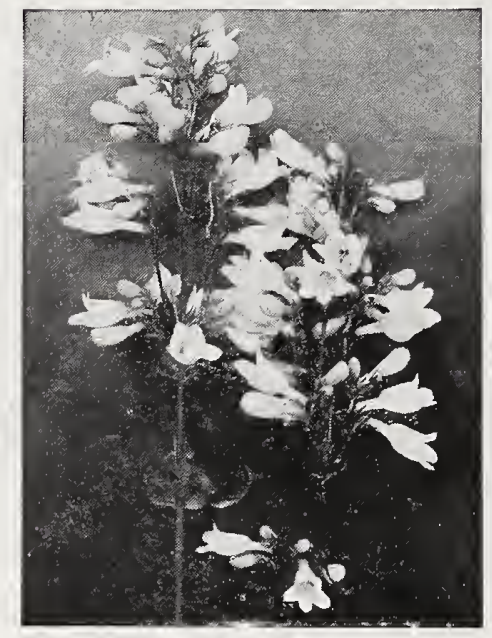

Pentstemon Digitalis.

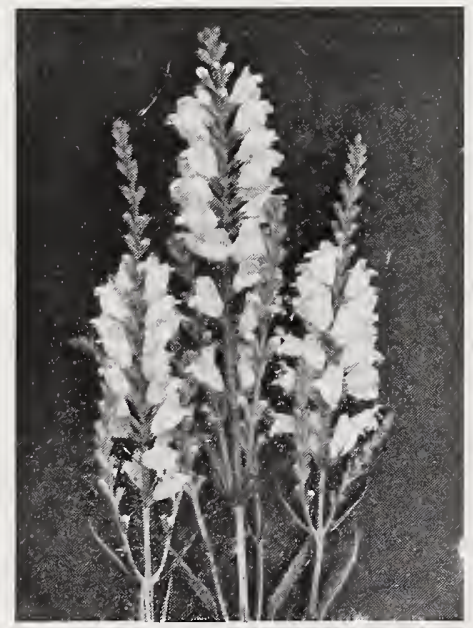

Physostegia Virginica, Vivid.
PAPAVER (Poppy).

Oriental Poppies are the regal representatives of this popular genus, growing 3 to $3 \frac{1 / 2}{2}$ feet high, and far surpassing in splendor of bloom all the annual and biennial kinds, and for a gorgeous display of rich and brilliant coloring nothing equals them during their period of flowering in May and June, and whether planted singly or in masses their large flowers and freedom of bloom render them conspicuous in any position. They are of the easiest culspicuous in any position. They are of the easiest culture; almost any kind of soil suits them, but they du best early Spring before the first of May-give them water occasionally during dry spells in the early part of the season. Mulch with stable litter in the Fall; and they will increase in size and floriferousness for several years. We offer the best of the latest introductions, as well as the distinct standard varieties.

Orientale (Oriental Poppy). Tremendous scarlet, cup-shaped blooms of brightest crimson-scarlet, with large, purplish black blotches at base of petals, creating a wonderful contrast when bloom is fully open Clumps of these throughout the border add a brilliancy

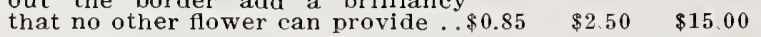

Orientale, Apricot Queen. Large,

apricot Apr. Quec......... $1.00 \quad 3.00 \quad 20.00$

Orientale, Beauty of Livermore. Crimson, with black blotch; fine

flowers $\ldots \ldots \ldots \ldots \ldots \ldots \ldots \ldots \ldots \ldots \ldots$.

crimson. (Sold out until next season).

Orientale, Mrs. Perry. Orangeapricot; very fine $\ldots \ldots \ldots \ldots \ldots$

Orientale, Princess Victoria Louise.
Bright salmon-scarlet; very fine..

Orientale, Perry's White (New. The most distinct break in Oriental Poppies that has yet been made: the flowers are a fine satiny white with a crimson-maroon blotch at the base of each petal. (Sold out until next season. )

Orientale Hybrids, Mixed. Saved from named sorts of the large perennial Poppies ...............

PENTSTEMON (Beard Tongue)

Most useful and showy perennials. Some varieties are not hardy. Those below are perfectly so. June and July. 3 feet.

Barbatus Torreyi. Spikes of bright Three Doz. 100 acarlet Torreyi. Spikes of bright scarlet flowers from June till Au-
gust. A very effective plant for hardy beds $\ldots \ldots \ldots \ldots \ldots \ldots \ldots \ldots 0.85 \$ 2.50 \$ 15.00$

Digitalis. White Foxglove-like spikes $\ldots \ldots \ldots \ldots \ldots \ldots \ldots \ldots \ldots$.

Huntington's Shell Pink (New). A wonderful addition to this class. Spike is not as tall and "stringy" as Torreyi, and flowers are more plentiful on the spike. Color is a hardy in any soil or climate ... $1.35 \quad 4.00 \quad 30.00$

PHYSOSTEGIA (False Dragonhead).

virginica. Forms large clumps 3 to 4 feet high, bearing long spikes of delicate pink flowers, tubular in form. July and August ........

Virginica alba. Pure white $\ldots . . .$.
virginica, vivid. This is a seedling Virginica, Vivid. This is a seedling
of our own; it blooms three weeks later than the others and the flowers are a deeper color pink; much larger and better, lasting a long time when cut .............. 1.00

POTENTILLA (Cinquefoil).

Charming plants for the border, with brilliant single or double flowers that are produced in profusion from June to August. Succeeds in any soil. 18 inches.

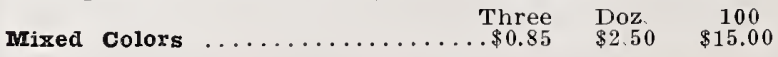




\section{Terbaceous and Alpine Plants}

1.

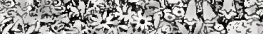

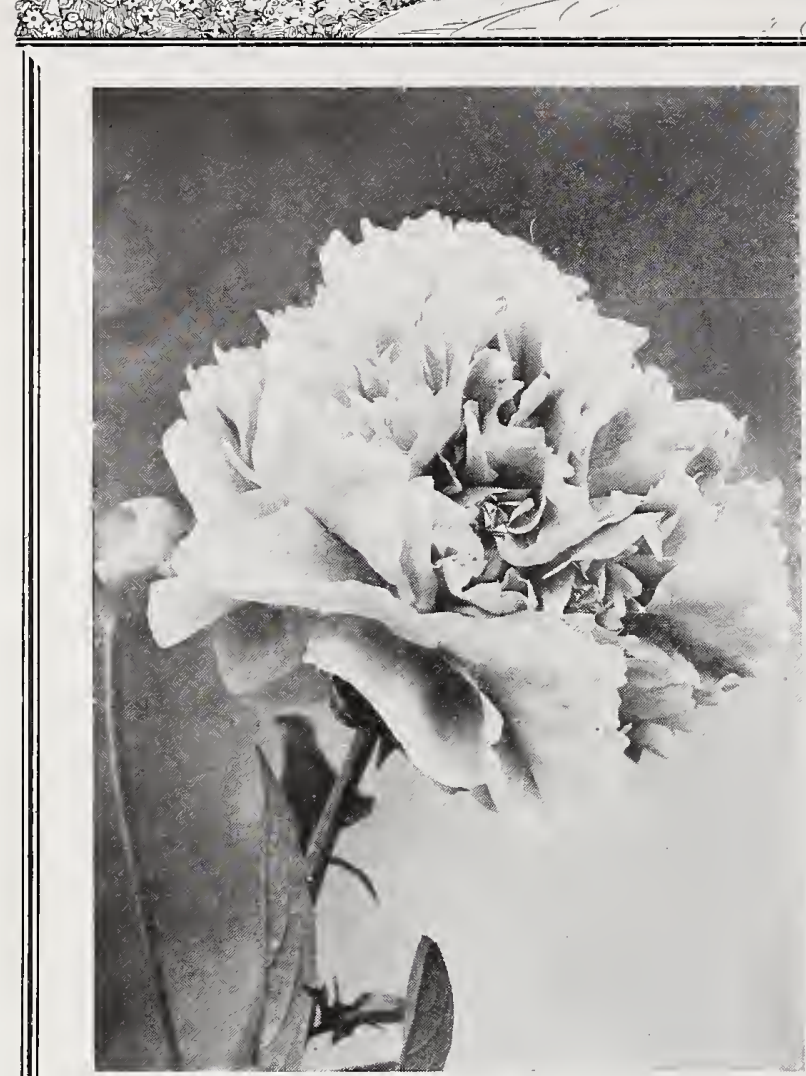

Eugenie Verdier.

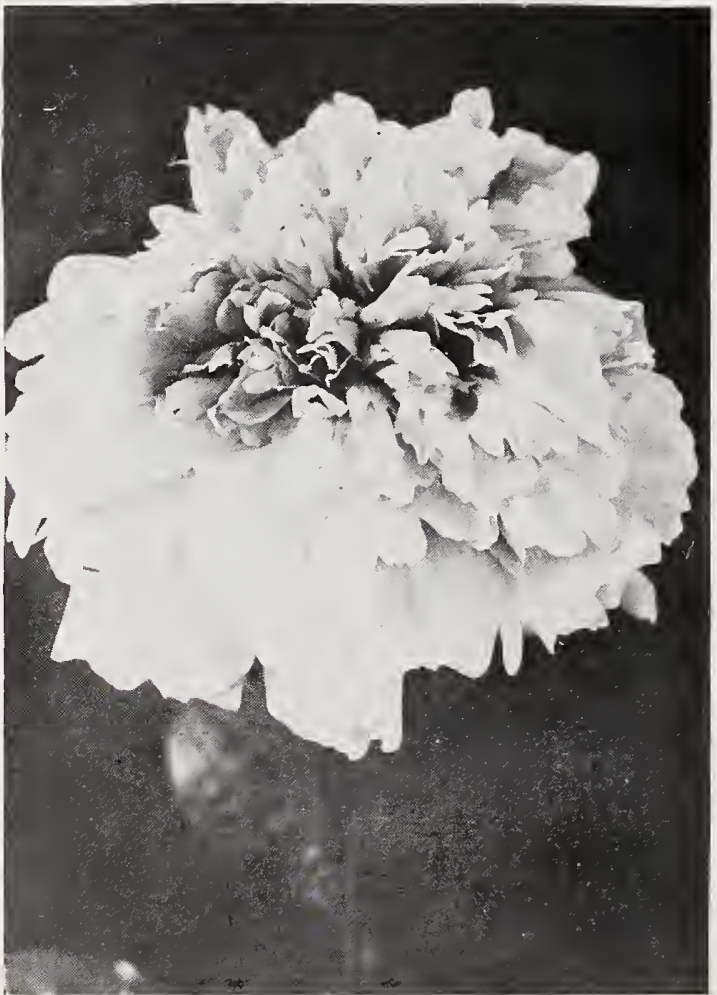

Mad. Crousse.
PFonifs-Continued.

$\begin{array}{cc} & 3-Y r . \\ \text { Each Eyes } & \text { Clumps } \\ \text { Doz. } & \text { Each }\end{array}$

Gloire de Boskoop. 7.6. Pure white.

Tall, strong grower; choice va- $80.66 \quad \$ 6.50 \quad \$ 1.25$

Karl Rosenfield. 8.8. Very large

flower, globular, semi-rose type.

Extremely vigorous grower, tall,

and free-flowering. As an early

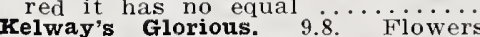

large, full, double rose type; cream-

white, overlaid with a soft blush of rose; very exquisite; fragrant: late midseason. Considered by many as the finest of Kelway's many as the nnest of Kelway's

Ia Tulipe. 7.5. (Calot, 1872). (Syn. Multi-color Calot, 73 ). Lilacwhite, outer petals striped with crimson. Large, flat, rose type fragrant; very tall, strong growth.

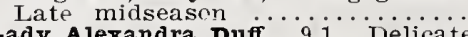

工ady Alezandra Duff. 9.1. Delicate pale pink fading to white. Main flower large, cup-shaped, rose type. Blossoms form side buds of ten semi-double, exposing the anthers;

I Cygne. 9.9 . Very large, perfecti

Le Cygne. 9.9. Very large, perfectly formed flower, freely produced; cream-white with a touch of green at the heart. The finest white. Re-
ceived the highest rating of any ceived the highest rating of any

Madame Ducel. 7.9 ( Mech. 1880 ). Large, globular, typical bomb. Light mauve-rose, 1(153), with silvery reflex. Fragrant. Stron grower, medium height; very free. Extra $\ldots \ldots \ldots \ldots \ldots \ldots \ldots \ldots$

Ime. Emile Galle. 8.5. (Crousse, 1881). Very soft pink, changing to milk-white in center. Very large. compact, flat, rose type; tall, strong, fragrant. Late $\ldots$. . W W
mme. Crousse. 7.9. Pure white with

Mme. Crousse. 7.9. Pure white with
faint crimson markings. Large, globular, crown type; fragrant medium height. Midseason ..... Mme. Forel. (Crousse, 1881). Enormous, very full, double bloom color glossy, deep pink with a silvery reflex; known as the "Princes of Pink Peonies," a title it well deserves and proudly carries. Ex-

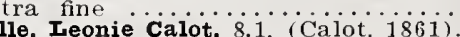

Mlle. Ieonie Calot. 8.1. (Calot, 1861) Very delicate shell pink, center
darker. Medium size, very comdarker. Medium size, very com-
pact, globular; on weak stems Late midseason.$\cdots$ Calot $_{1869}$ )

Marie Lemoine. 8.5. (Calot, 1869) Pure white with cream-whit center. Large, very compact, rose height; extra strong stems. Very

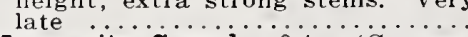

Marguerite Gerara. 8.4 (Crousse 1892). Very pale salmon-pink fading to almost white. Large. compact, rose type; very strong growth. Late 8.5 (Calot, 1868 ). Lilacwhite fading to milk-white. Medium size, compact, rose type; fragrant; very tall. Very late ... Mons. Dupont. 8.3. Very large, cupshaped flower; ivory-white; center petals splashed with carmine. The golden stamens show at the base of the petals; fragrant; a strong grower; very tall; midseastrong grower, very this season)

Mons. Martin Cahuzac. 8.8. Medium sized, globular, semi-rose type. sized, globular, semi-rose type. reflex. The darkest Peony known. Strong, vigorous grower, free bloomer midseason ............ Martha Bulloch (Brand. 1907) Mammoth cup-shaped blossom often to 12 inches across. The largest of the good Peonies. Deep rose-pink in the center, shading to silvery in the center, shading to silvery Stalks strong and erect. (Sold out for this season). $\begin{array}{lll}.75 & 7.50 & 1.75\end{array}$ 


\section{Herbaceous and Alpine Plants IN W (t)}

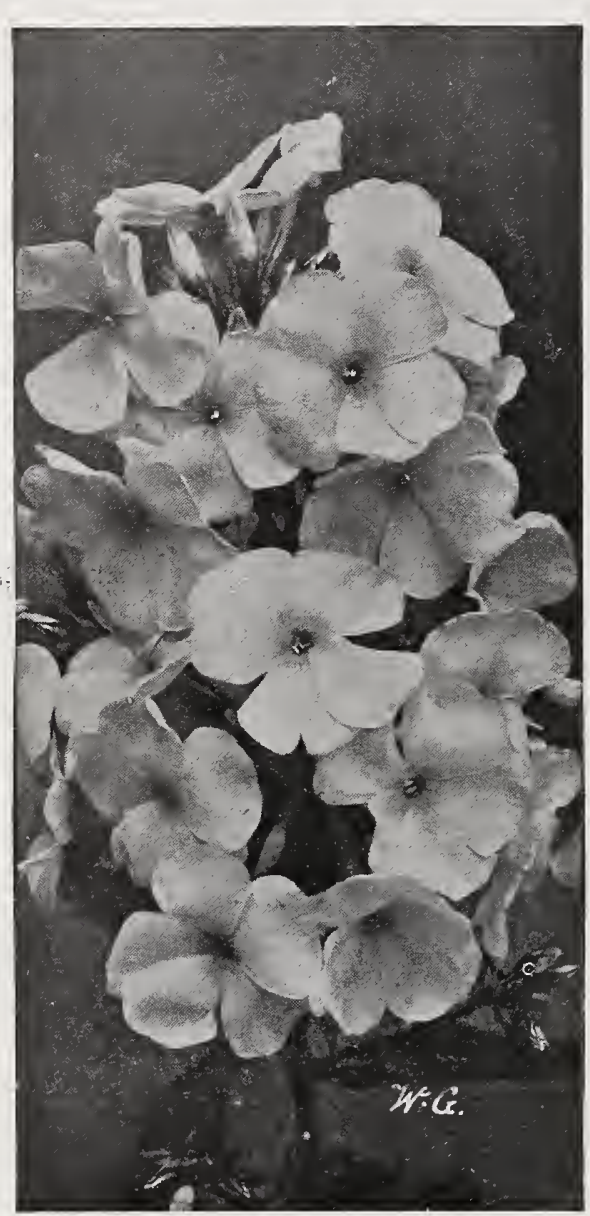

Phlox, Miss Lingard.

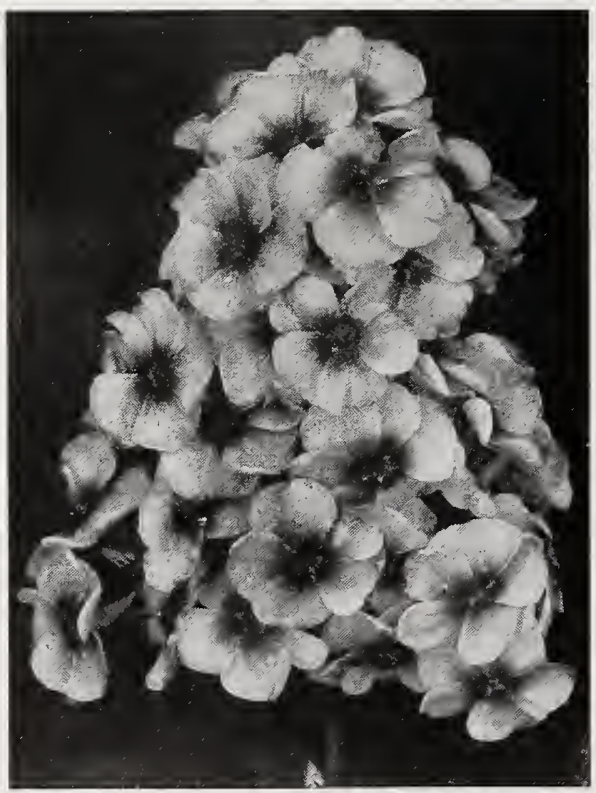

Phlox, Europa.
PrONIFS-Continued.

Strong

Divisions,

No. 88. Oki-no-nami. Tall, free flowering and showy. Pale hydrangea-pink, with full, fine-cut center of peach-pink and cream. It does not require a strong imagination to get the Japanese descriptive impression ................ 5.00 No. 135. Kara-ori-nishiki. This shows uniquely fluted petals, with ends deeply indented. These are white, irregularly streaked and tipped with with deep gold filaments, and carmine seed pods. 5.00

\section{PHLOX.}

\section{PHIOX DECUSSATA (Hardy Phlox).}

Perennial Phloxes succeed in almost any soil enriched with manure in Spring, and in hot weather an occasional soaking of water. If the first spikes of bloom are removed as soon as over, they will produce a second supply of flowers, continuing the display until late in Autumn. These later blooms are often finer than the first.

(We offer nothing but strong, 2-year-old plants).

(*These for rall delivery, 1926). Three Doz. 100

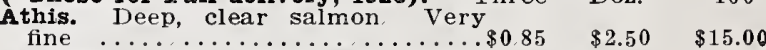

*Africa. Ruby-crimson with darker 1.50

Antonin Mercie. Clear lilac with

white eye. Extra large ....... $100 \quad 3.00 \quad 20.00$

Beacon. Brilliant cherry-red ... $1.00 \quad 3.00 \quad 20.00$

B. Comte. Rich satiny amaranth $\ldots \quad .85 \quad 2.50 \quad 15.00$

* Clara Benz. Brilliant rosy carmine,

with white eye and lolet halo; 1.50

crepuscle. White with delicate mauve suffusion and rosy purple

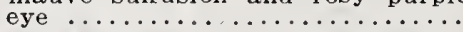

Champs Ilysee. Fine, rich crimson..

Commander. Beautiful New. Crimson-red with darker eye. The most striking of Phloxes .......

* Ivelyn. Rich salmon-rose, flowers large and of perfect form. 3 feet.. 1.50

* Graf zeppelin. White with red

eye, better than Europa …... 1.50

Eclaireur. Bright carmine with

ing

Eiffel Tower. Pink with deep pink 100

eye Very tall grower ........ pink, with lighter shadings and dark red eye; one of the handsomest and most attractive ... $1.20 \quad 3.50$

* Fthel Pritchard. Grand light lilac $1.50 \quad 4.50$

suropa. A new variety, white with large crimson-carmine eye. Very large flower and truss .................

Fuerbrand. Bright vermilion-scarlet.

New variety $\ldots \ldots$ Tender peach-blossom pink with bright rose eye, creating a
soft mauve effect. Flower and truss very large on erect, compact stems $\ldots \ldots \ldots \ldots \ldots \ldots \ldots$

* Imperator. Brilliant, dark carminered flowers, with darker eye .... Jules Sandeau. Large, fine, very

free flowering pure pink .......... older varieties of similar color with immense, conical heads, borne in great profusion. Warm mauve in great profusion. Warm mauve with emphatic carmine eye ....

Mrs. Jenkdns. White; immense panicles; free bloomer Dark saimonpink flowers in enormous pyramidal spikes ………… Soft pink, without eye. Large flowers on long, erect spike .... Prof. Verschouw. Bright carmine, overlaid with orange-scarlet .... Pantheon. Clear, deep, carmine-pink

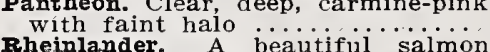
Rheinlander. A beautiful salmon
pink, with flowers and trusses of R. P. Struthers. Bright rosy-carmine, with claret-red eye ...... Rijnstroom. Lively rose-pink, much like Paul Neyron rose. Immense trusses of flowers .............

\section{$85 \quad 2.50 \quad 15.00$}

$3.50 \quad 25.00$ 

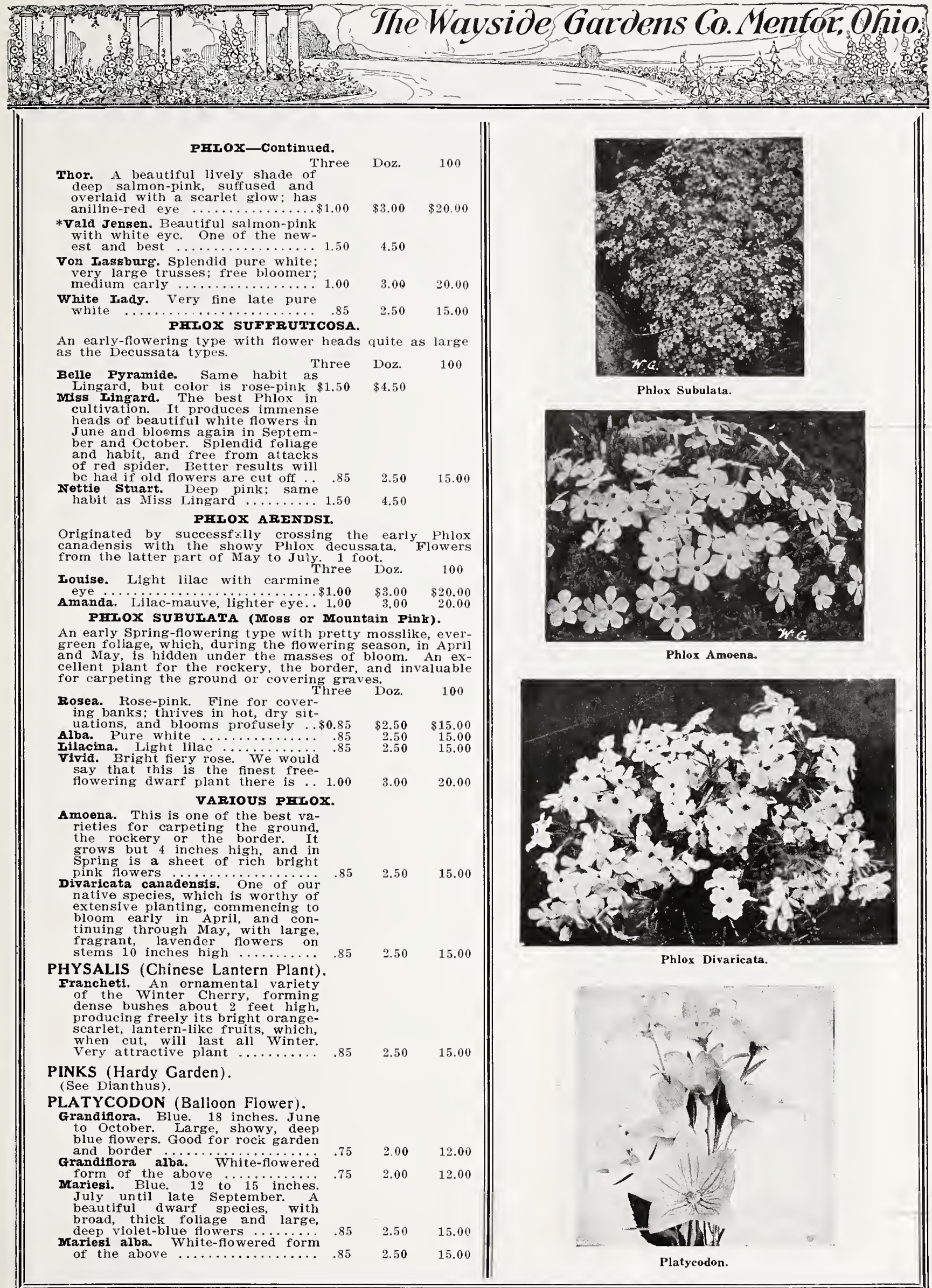


\section{Terbaceous and Alpine Plants}

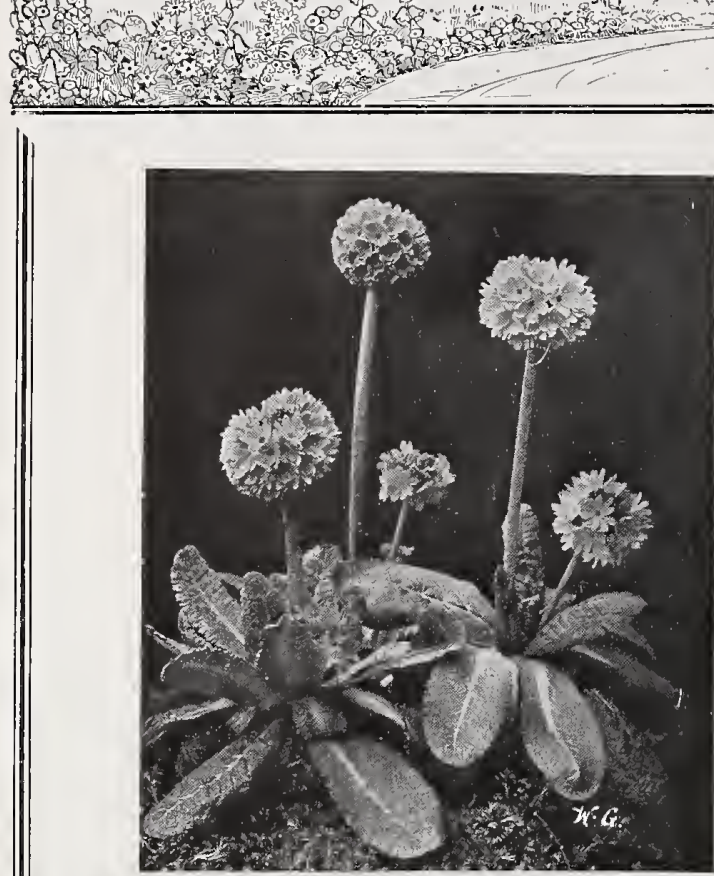

Primula Cashmeriana.

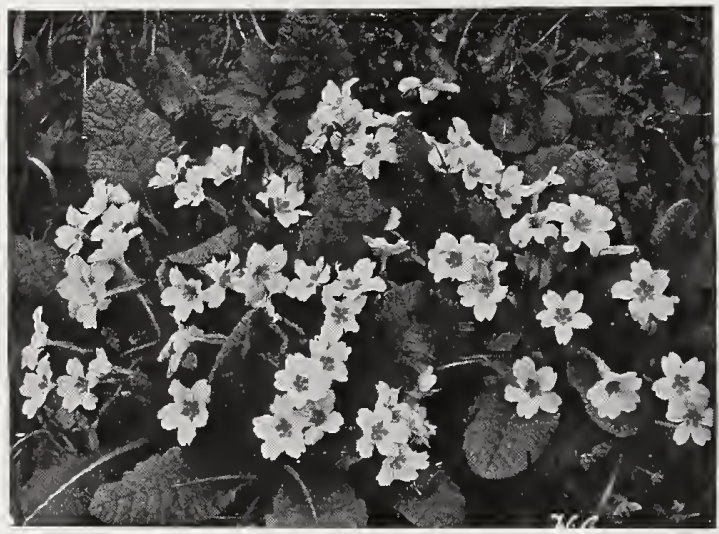

Primula Veris.

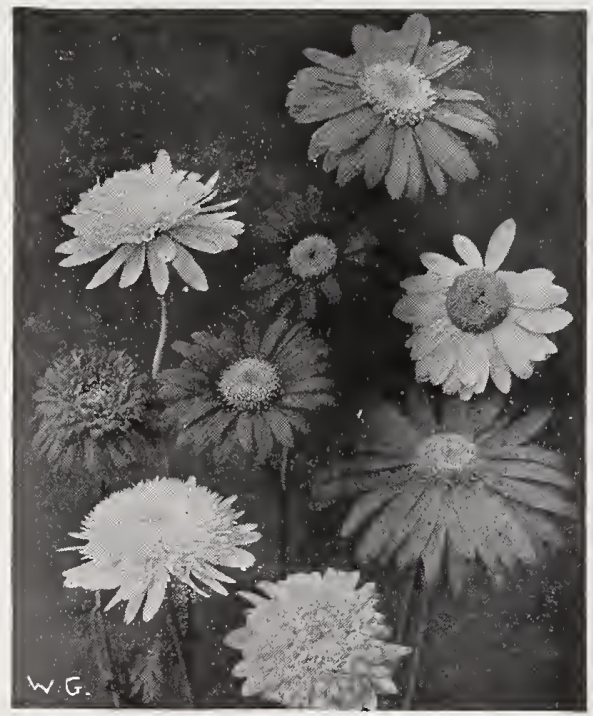

Pyrethrums.

PLUMBAGO (Leadwort).

Iarpentae. One of the most Three Doz.

sirable border and rock plants. It

is of dwarf, spreading habit, grow-

ing 6 to 8 inches high, covered

with deep blue flowers during the

Summer and Fall ................
LEMONIUM (Jacob's Ladder).

Humile coeruleum (Richardsoni) Erect stems of sky-blue flowers. 1 $\$ 0.85 \$ 2.50 \quad \$ 15.00$ rumile album. A white variety of

Humile album. A white variety of

Reptans (Greek valerian). $\dot{8}^{2}$ to 10 inches. April to June. Dwarf, bushy plant of graceful growth. Showy blue flowers. Rock garden and fine border plant .............. Mrultiflorum major. Pendent sprays of greenish white flowers borne on
long stems, 2 feet. May and June. long stems, 2 feet. May and June. tion, where it has plenty of room to show off its wonderful pendulous sprays of bells. Fine for cutting ( $\ddot{\text { Hardy }}$ Primrose).

Splendid little plants for naturalizing near shrubs, in the border or shaded nooks on the rockery. Cashmeriana (New), Large, globular heads of a pleasing purplish blue shade; prefers a moist shaded situation ............................ various shades of lilac purple and various shades of lilac purple and buff, orange, salmon and rich reds approaching scarlet in intensity. Quite hardy and of vigorous Quite hardy and of vigorous vugaris. The old English Primrose with pale yellow flowers ...

$85 \quad 2.50 \quad 15.00$

$85 \quad 2.50 \quad 15.00$

$\begin{array}{ll}1.00 & 3.00 \quad 20.00\end{array}$ $0.85 \$ 2.50 \$ 18.00$ $1.00 \quad 3.00 \quad 20.00$

PRUNELLA (Self-head; Heal-all).

Grandiflora. Violet or purple flowers all summer. Fine for the rockery or slightly shaded parts of the hardy border. Succeeds in any soil not excessively dry 1.00

The Pyrethrums are so simply and easily cultivated that they may be recommended to all who possess a garden. They are perfectly hardy and absolutely invaluable for cut flowers through the summer and early Fall. The flowers are bright and elegantly borne on long stems: most convenient for decoration. In form, the double varieties are somewhat aster- or chrysanthemum-like, and as their chief beauty is in the months or May and June, they may well be designated Spring Chrysanthemums, possessing the advantage over the Chrysanthemums of being able to withstand the severest Winter without protection. The single-flowered varieties are variable colored Marguerites and possess a range of color and hardiness that Marguerites might envy in vain. Nothing of flowers ing can surpass the Pyrethrum prof throughout the entire summer from at the blossoms are not injured by storm or sun. As a cut purposes. Their position should be in the border or in beds.

All Colors Mized. Strong, 2-year Three Doz. 100

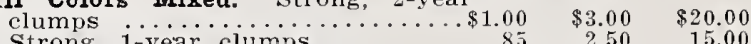

RANUNCULUS (Buttercups).

Repens fl. pl. A pretty, double-flow ering, bright golden yellow butter cup; masses of flowers in May and June $\ddot{\text { JuB }}$ (Coneflower).

Golden Glow. One of the most popular hardy plants. Grows six feet hiar hardy plants. Grows six feet high, producing masses of large, double, golden yellow flowers, shaped like a cactus dahlia .... the "Black-Eyed Susan." Deep orange-yellow flowers, with a dark purple cone: long, wiry stems 3 feet high: blooms all Summer.

Purpurea (Giant Purple Coneflower).

Peculiar reddish purple flowers,

with a very large, brown, coneshaped center. Blooms from July to October 3 feet ...........
$85 \quad 2.50 \quad 15.00$

$\begin{array}{lll}75 & 2.00 \quad 12.00\end{array}$

$\begin{array}{lll}75 & 2.00 & 12.00\end{array}$ 


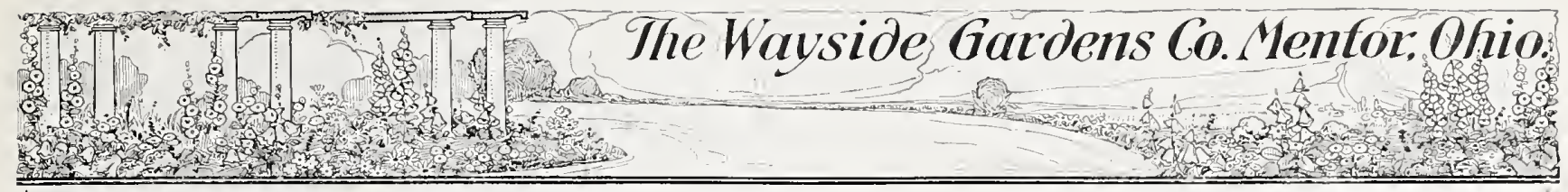

\section{RUDBECKIA-Continued.}

Maxima. A rare and attractive variety, growing 5 feet high, with large, glaucous green leaves an bright yellow howers 5 to 6 inches across, with a cone 2 inches high flowers continuously fror

LVIA (Meadow Sage)

Azurea. A Rocky Mountain species. Grows 3 to 4 feet high, producing during August and September pretty sky-blue flowers in the

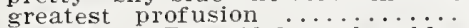

Farinacea. Beautiful pale blue

flowers similar to the above, but of more branching habit and large flowers of a rich gentian-blue color, and one of the most admired plants by the many visitors to our nurseries during the early Autumn. 3 to 4 feet ............ J'une

Turkestanica. Extremely decorative sweet scented foliage and showy whorls of white flowers surround-

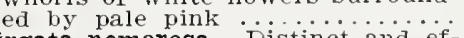

virgata nemorosa. Distinct and effective foliage with showy whorls $1.00 \quad 3.00 \quad 20.00$

SANTOLINA (Lavender Cotton; Ground Cypress).

A sweet smelling, dwarf, evergreen perennial, with delscate, silver-white foliage, useful as rock or border plants: also largely used in carpet bedding.

Chamaecyparissus (incana). 1 foot $\$ 0.85 \quad \$ 2.50 \quad \$ 18.00$

SAPONARIA (Soapwort).

Ocymoides splendens. Pretty border and rockery plant; flowers rosy pink ................... Ocymoides alba. A grand pure

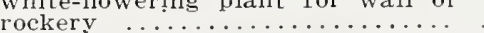

SAXIFRAGA (Megasea).

Iigulata. These will thrive in any kind of soil and in any position. Grow about 1 foot high, and are arow about 1 foot high, and are border or shrubbery forming border or shrubbery, forming masses of handsome, broad, deep green foliage, which alone renders them useful, while the pretty flowers, which appear very early in the Spring, some almost as ground, make them doubly effect-

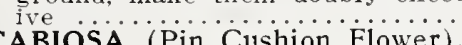

$85 \quad 2.50 \quad 18.00$ $85 \quad 2.50 \quad 18.00$ Handsome border plants, succeeding in any ordinary soil if well drained and in a sunny location, and should be grown in every garden where cut fowers are wanted they last a long time when picked and placed in water

Calucasica (Blue Bonnet). A soft and charming shade of lavender commences to bloom in June throwing stems 18 to 24 inches high until September ..........\$1.20 \$3.50 $\$ 25.00$ Caucasica alba (White Bonnet). The white form of the preceding ..... from July to September; 2 feet .

Pennsylvanica (Cephalaria tatarica).

Large golden yellow flowers, simi-

lar to the true Scabiosa in form.

SCUTELLARIA (Skuli Cap)

Baicalensis coelestina. Short, wiry stems, clothed with clear blue Snapdragon-shaped flowers. One foot. June to August ........ 1.20 3.50

SENECIO (Groundsel).

Clivorum. Forms a neat tuft of foliage, from which spring up from July to October a succession of 3 -foot stems, with clusters of

SIDALCEA (Greek Mallow).

Erect-growing, more or less branching plants, producind their showy flowers during June and July. They wil. succeed in any garden soil in a sunny position.

\begin{tabular}{ccccc} 
Rosy Gem. Pretty, bright rose & \multicolumn{2}{c}{ Doz. } \\
colored flowers. 2 to 3 feet $\ldots \ldots . \$ 0.85$ & $\$ 2.50$ & $\$ 18.00$
\end{tabular}

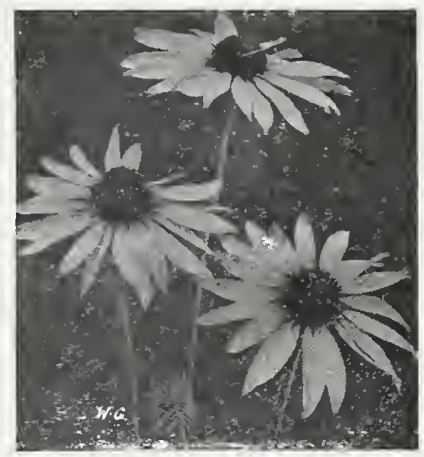

Rudbeckia-Coneflower.

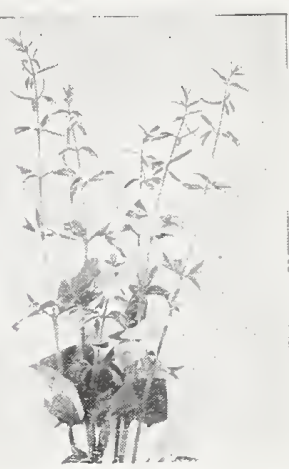

Salvia Pratensis.

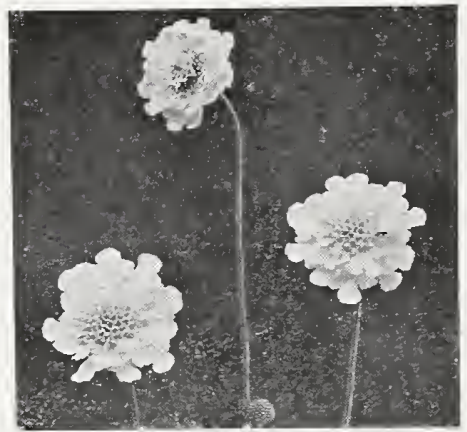

Scabiosa.

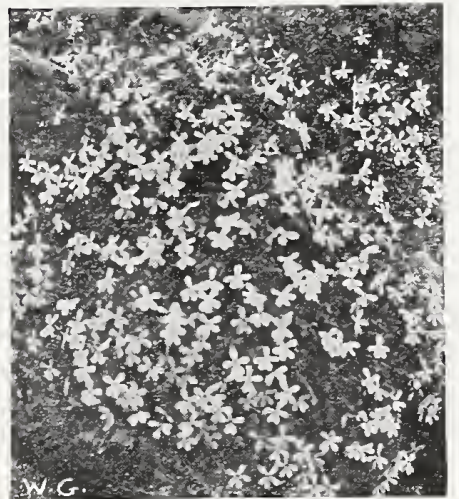

Saponaria Ocymoides. 


\section{Merbaceous and Alpine Plants}

\section{(1)}

T.

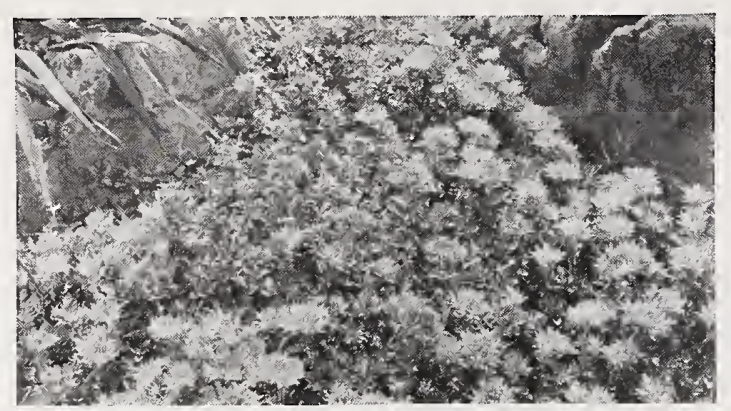

Sedum Spurium Coccineum.

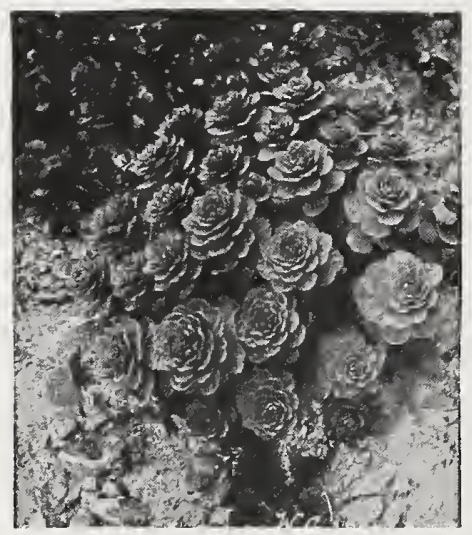

Sedum Sexangulare.

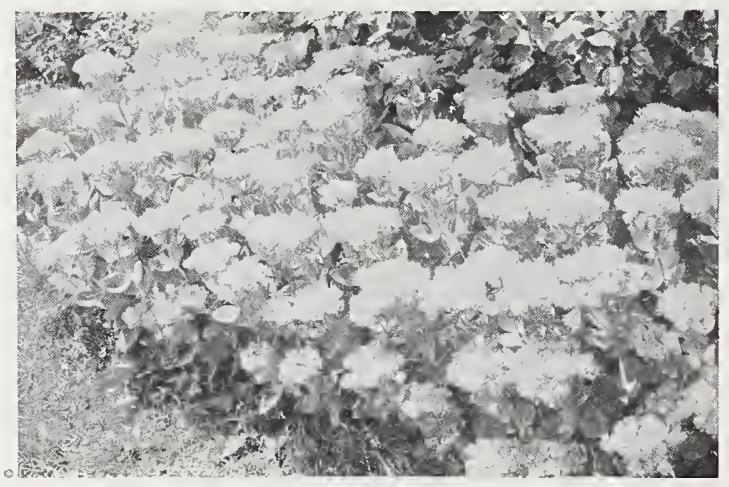

Sedum Spectabile.

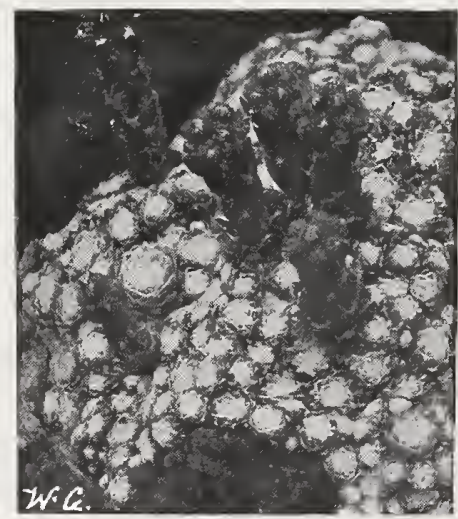

Sempervivum.
SILENE (Catchfly).

Schafta (Autumn Catchfly). A growing from 4 to 6 inches high, with masses of bright pink flow-

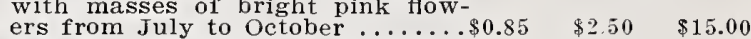

ers from July to October .......
Alpestris. Dwarf rock plant, dainty

pure white flowers in May and $1.00 \quad 3.00 \quad 20.00$

SISYRINCHIUM (Satin Lily or Blue-Eyed Grass).

Bermudianum. A pretty early Spring

$\begin{array}{lllll}\text { and Fall flowering plant with blue } & & & \\ \text { flowers and grasslike foliage } & \ldots & .85 & 2.50 & 15.00\end{array}$

SEDUM (Stonecrop).

DWARF VARIETIES.

America's greatest rock plant. Suitable for the rockery. carpet-bedding, covering of graves, etc.

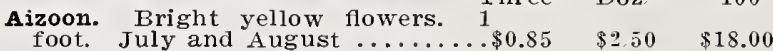

Acre (Golden Moss). Much used for covering graves; foliage green;

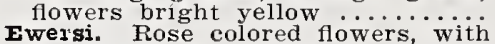

Ewersi. Rose colored flowers, with
glaucous gray foliage; sub-trailing habit .....................

Sarmentosum. Excellent dwarf va-
riety for rockeries or border edgings .............................. cla rockeries or border edgings

rernatum. Excellent dwarf variety

for rockeries or border edgings.

sexangulare. Very dark green foli-

sexangulare. Very dark green foli-

siebolai. Round, succulent, glaucoùs foliage; bright pink flowers in August and September ..........
stolonifera. One of the most desir-

stolonifera. One of the most desir-
able; flat, succulent leaves; flowers purplish pink; July and August;

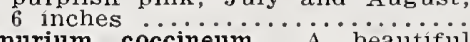

spurium coccineum. A beautiful rosy crimson-flowered form; July

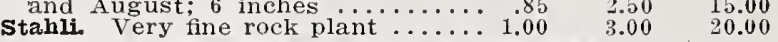
ER ECT-GROWING VARITTIES.

Useful and pretty plants for the border, producing their interesting flowers during late summer and Fall.

spectabile. One of the prettiest Three Doz.

pectabile. One of the prettiest

height of 18 inches, with broad,

light green foliage and immense

light green foliage and immense

colored flowers; indispensable as

a late Fall-blooming plant $\ldots \ldots . \$ 0.85 \quad \$ 2.50 \quad \$ 15.00$

spectabile "Brilliant." A rich col-

ored form of the preceding, being
a bright amaranth-red ..........

15.00

DWARF AND RARE SEDUMIS.

Kamschaticum. Orange-yellow flow-

ers, with prostrate, green foliage,

turning golden in Áutumn ...... $1.35 \quad 4.00$

camschaticum fol. var. Similar to

above, but has attractive, varie- 135

30.00

obtusatum. Golden yellow flowers

with emerald-green foliage, shaded

Pruniatum Forsterianum............

glaucous, bluish green leaves, of

glaucous, bluish green leaves, of

low flowers

30.00

SEMPERVIVUM (House Leek).

Curious and interesting plants forming rosettes of succulent leaves of varying colors. Good for rockeries, dry banks, carpet bedding or walls. (For Fall delivery, 1926).

Arachnoideum (Cobweb House Leek) Leaves in rosettes usually con-

nected by silvery threads. Flow-

ers bright red. 6 inches .......\$1.35 $\$ 4.00 \quad \$ 30.00$

Atroviolaceum. Large rosettes of a

deep green color; shaded red $\ldots$
Browni. Grayish green rosettes $\ldots$
$\ldots$

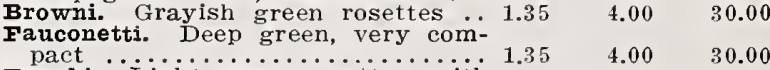

Funcki. "Light green rosettes, with

heavy edges - flowers bright pur-

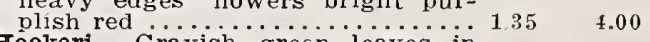

30.00

Hookeri. Grayish green leaves in
flat rosettes, flowers dull red.... $1.35 \quad 4.00$ 
SPIREA (Goat's Beaıd; Meadow Sweet).

Elegant border plants with feathery plumes of flowers and neat, attractive foliage; succeeds in all locations.

Kneiffi. Very graceful foliage, finely $\begin{array}{llll}\text { cut into hairlike segments, with } & & \\ \text { large cream colored flower spikes. } \$ 2.00 & \$ 8.00 & \$ 70.00\end{array}$

Ulmaria fl. pl. The well known double "Meadow Sweet." Creamy white flowers ................. $1.00 \quad 3.00 \quad 20.00$

Venusta. A fine plant for moist situation, large, flat heads of pink flowers …......................... $2.00 \quad 8.00$

Filipendula (Dropwort). Numerous
corymbs of white flowers on stems 15 inches high. June and July; pretty fernlike foliage ........... $.85 \quad 2.50 \quad 18.00$

Filipendula flore pleno. 12 to 18 inches. June and July. Double
white flowers, fernlike foliage $\ldots$
...00

Aruncus. 4 feet. Junc. Produce

rung, feathery panicles of white

long, feathery panicles of white
flowers, forming graceful plumes. $2.00 \quad 8.0 \%, \quad 70.00$

Palmata elegans. 3 feet. June to

August. Graceful plumes of lovely light pink flowers. Fine for waterside planting ............. $1.00 \quad 300 \quad 20.00$ SPIREA ASTIIBE.

(Arendsi and Japonica Hybrids).

Hybrid varieties of very vigorous growth, producing many-branched, feathered heads of flowers in June and July. They prefer a half-shady, moist position in any ordinary garden soil. Field grown clumps.

Three Doz. 100

America. Deep pink; excellent forc-

Petsy Cuperius. The drooping spikes of flowers have a length of over 2 fcet, and are a beautiful creamy

white, with pink centers. 5 to 6
feet ........................ $2.75 \quad 10.00 \quad 75.00$

Brunhilde. Creamy white, shaded ilac ..................2.00 $7.00 \quad 50.00$

Ceres. Light rosy pink, with silvery hue .......................... 2.00

Davidi. Large plumes of violet flowers; 5 to 6 feet ............. 2.00

Deutschland. Purple pink ...... 2.75

Emaje. Rich magenta .......... 2.75

Grandis rosea maxima. A splendid pink sort growing 4 feet high ...2 2.00

Gladstone. 18 inches. June-July. A fine variety. Immense trusses of flowers are as white as snow, borne on erect, strong stocks ...2 2.00

Gunther. Rosy pink ........... 3.00

Marguerite Van Rechteren. Grows about 5 feet high. The flower stem has a length of over 3 feet. The very fine fringed flowers are bright red tinged with dark lilac. 2

meta Immink. Dense plumes of

bright pink Very fine ...... 200

Mowe. Bright pink .......... 2.75

Prof. Weilen. Loose panicles of small, white flowers; exceedingly pretty ........................... 3.00

Theinland. A lovely blend of rich crimson and salmon ............. 2.75

Rubens. Rosy red; new and good; fine for forcing ............. 2.00

Salland. Grows over 6 feet high with flowers of a distinct red color ... 2.00

Queen Alexandra. Light pink; good for forcing ................. 2.00

vesta. New. Tall, lilac-rose spikes; beautiful garden variety .. 275

Van Den Bosch. Good border plant. 2.75

STACHYS (Woundwort).

ranata. Fine old-fashioned cottage garden plant for edging; useful in rock garden; dwarf; soft silvery foliage; flowers useless. 4 inches

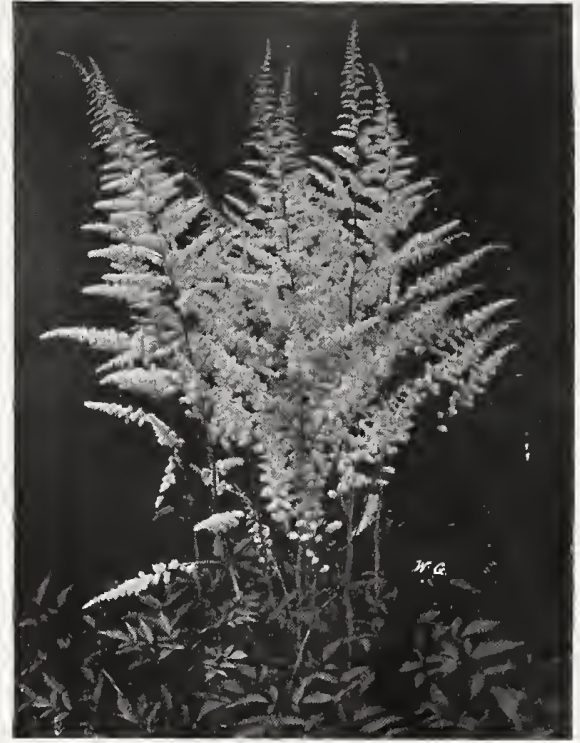

Spirea Gladstone.

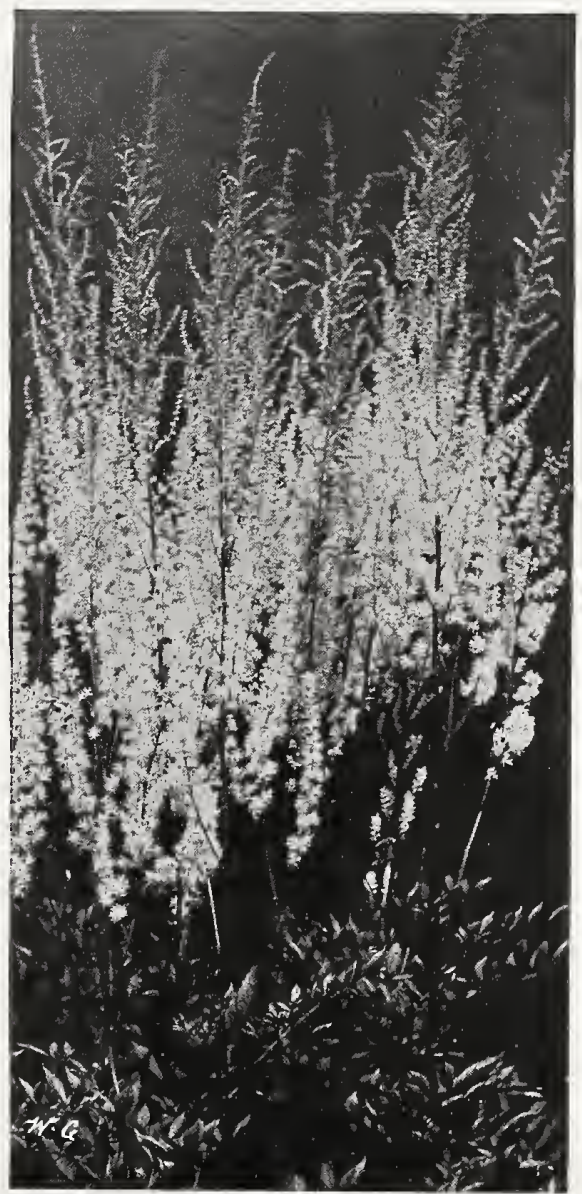

Astilbe Arendsi Hybrid, Grandis Rosea Maxima. 


\section{Terbaceous and Alpine Plants}

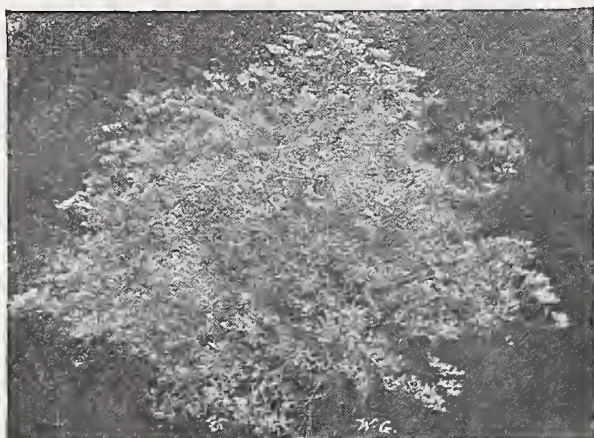

Statice Latifolia.

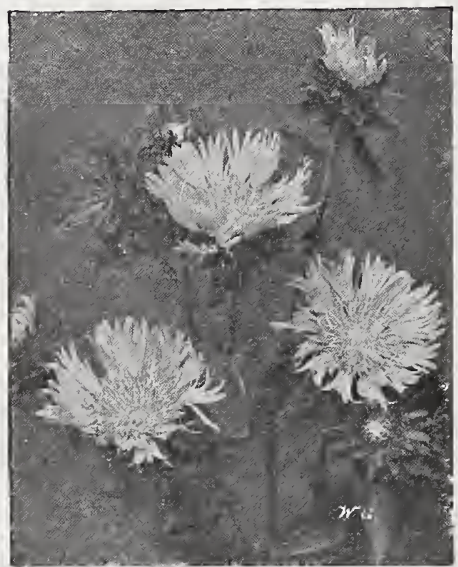

Stokesia Cyanea.

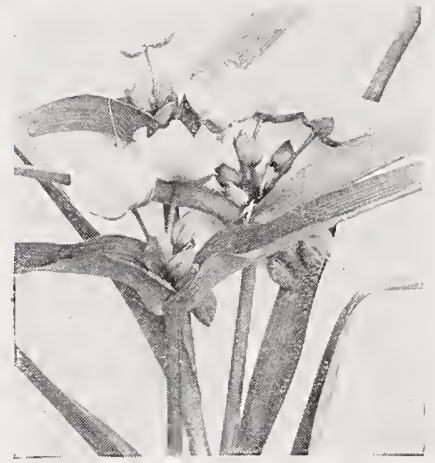

Tradescantia Virginica.

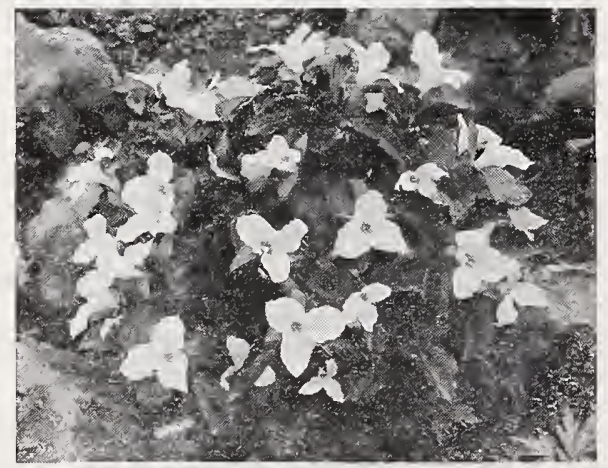

Trillium Grandiflorum.
STATICE (Great Sea Lavender).

Iatifolia. A valuable plant eithe Three Doz. $\quad 100$

for the A valuable plant either

tufts of leathery leaves and im-

mense candelabra-like heads, fre-

quently $1 \frac{1 / 2}{2}$ feet high and 2 feet

across, of purplish blue, minute

flowers during July and August.

perfect condition for months ...\$0.85 $\$ 2.50 \quad \$ 15.00$

Incana. White form of the above $\ldots \quad .85 \quad 2.50 \quad 15.00$

STENANTHIUM (Mountain Feather Fleece).

Robustum. A rare perennial, with

showy panicles of pure white,

fleecy flowers in August and Sep-

tember on stems 4 to 5 feet high;

requires a moist, semi-shady po-

$.85 \quad 2.50$

18.00

STOKESIA (Cornflower Aster; Stokes' Aster)

A most charming and beautiful native hardy plant which for many seasons, has been the most admired flower on our grounds. The plant grows from 18 to 24 inches high, bearing freely from early July until late in october its bearing freely from mandsome lavender-blue centaurea-like blossoms, which measure from 4 to 5 inches across. It is of the easiest culture, succeeding in any open, sunny position, desirable as a single plant in the hardy border and effective in masses or beds of any size.

Cyanea coerulea. Beautiful light

blue $\ldots . . .250 \quad \$ 18.00$

Cyanea coerulea alba. White-flowered
form of above. 1 to $11 / 2$ feet $\ldots . .85$

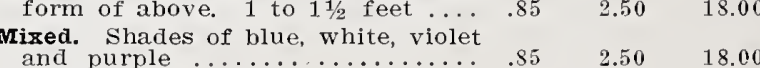

SWEET WILLIAM (See Dianthus Barbatus).

TEUCRIUM (Germander).

Chamaedrys. Shrublike habit. Ex-

cellent plant. Glossy green foli-

age, purple flower spikes in July

age, purple fower splkes in July $1.70 \quad 5.00 \quad 40.00$

THYMUS (Thyme).

The charming Mountain Thymes make a perfect, close, fragrant carpet on hot, dry, sunny banks where grass is difficult to establish; they are a sheet of blossom in June and July. Excellent for carpeting patches of Springflowering bulbs

(*These varieties ready Fall, 1925).

*Serpyllum (White Mountain Thyme). Forms dense mats of dark green foliage and clouds of white flowers. 3 to 4 inches. white flowers. 3 to 4 inches.

* Lanuginosus $\cdots($ i 0 oliy-i eaved). Woolly foliage with bright pink flowers ... Plants become completely covered with brilliant crimson-scarlet flowers ..........

*Album. A wonderful contrast with the preceding; flowers a sheet of

Citriodorus aureus. The golden yellow form of the well known "Lemon Thyme" ...............

Vulgaris. 6 inches. June and July. An old garden plant, being grown as a sweet herb; flowers small, lilac or purplish, in terminal, ingrant. Fine for rock garden ...

Doz. 100

$0.85 \$ 2.50 \quad \$ 18.00$ $1.00 \quad 3.00$ 20.00

TIARELLA (Miterwort).

Cordifolia. 6 to 12 inches. May, An elegant plant with fine foliage and small, creamy white, starshaped flowers. Prefers partial shade $\ldots \ldots \ldots \ldots \ldots \ldots \ldots \ldots$

virginiana. Produces a succession of blue flowers all Summer. 2 feet ............ $\ldots$ white-flowered

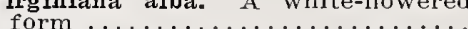

TRILLIUM (Wood Lily or Wake Robin)

Grandiforum. Excellent plants for shady positions in the hardy border, or in a sub-aquatic position. Large, pure white flowers in early Spling. 12 to 18 inches ........... 
THERMOPSIS (False Lupine; Buffalo).

Caroliniana. A showy, tall-growing plant, attaining a height of 3 to 4 feet, producing long spikes of yellow flowers in June and July $\ldots \$ 1.00 \quad \$ 3.00 \quad \$ 20.00$

THALICTRUM (Meadow Rue).

Aquilegifolium. Graceful foliage

like that of Columbine, and rosy purple flowers from May to July.

quilegifolium album. White form

quilegifolium album. White form

Adiantifolium. A beantiful variety. with foliage like the Maidenhair Fern and miniature white flowels

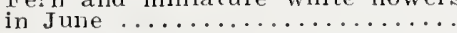

Dipterocarpum. A pretty and distinct species, with flowers of a charming shade of lilac-mauve, which is brightened by a burch of lemon-yellow stamens and anthers. The plant is of strong growth, about 4 feet high. The dainty flowers are produced in graceful

sprays during August and Sep-
tember ..................... $1.20 \quad 3.50 \quad 25.00$

Minus. Dwarf, with Maidenhair fernlike foliage $\ldots . .0000$

TRITOMA (Red Hot Poker; Flame Flower; Torch Lily).

Pfitzeri (The Everblooming Flame

Flower). The free and continuous blooming qualities of this variety have made it one of the great bedding plants, and when we consider that there are few fowering plants which are suitable for massing under our severe climatic conditions it is little wonder that such an elegant subject should become so popular. Succeeds in any ordinary garden soil, but responds quickly to liberal treatment Hardy if given protection, but the most satisfactory method of Wintering is to bury the roots in sand in a cool cellar. In bloom from August to October, with spikes 3 to 4 feet high, and heads of bloom of a rich orange-scarlet producing a grand effect either planted singly in the border or planted singly in the border or

Quartiniana. A strong growing thick stalked variety, blooming late in May with flower cones 10 to 12 inches long. Orange-red at first, but yellow on bottom half as bloom matures. Perfectly hardy here; does not need protection..

Uvaria grandiflora. 3 to 4 feet. The old-fashioned, late-flowering sort, with flowers rich red changing to salmon-pink. Needs slight protection .................. 1.20

TROLLIUS (Globe Flower).

Europaeus, Orange Globe. Desir able free-flowering plants, producing their giant bright yellow, buttercup-like blossoms on stems buttercup-like blossoms on stems August: succeed admirably in the

border in a half-shady position .. 1.70

5.00

40.00

TUNICA (Coat Flower).

Saxifraga. A pretty tufted plant with light pink flowers, produced all Summer. Useful either for the rockery or the border ........ $.85 \quad 2.50 \quad 18.00$

VALERIANA (Valerian; Garden Heliotrope).

Coccinea. Showy heads of old rose

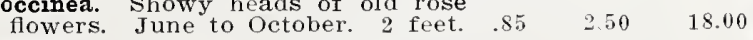

Offinalis (Hardy Garden Helio-

trope). Produces showy heads of

rose-tinted white flowers during

rose-tinted white rith delicious.

sune and July, 100

3.00

20.00

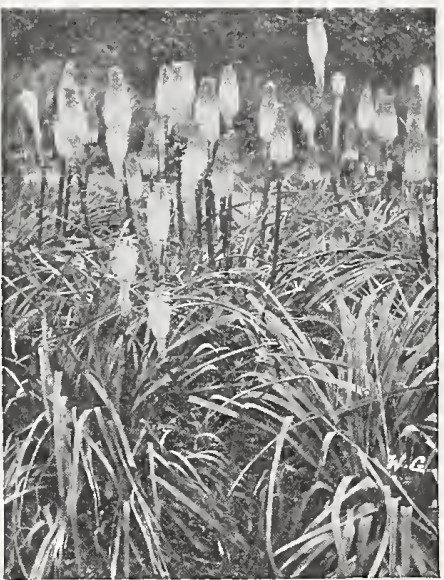

Pfitzer's Tritoma.

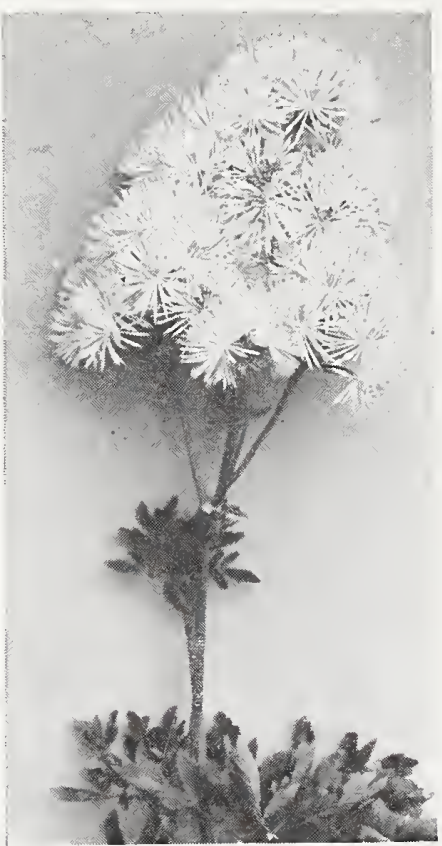

Thalictrum Aquilegifolium.

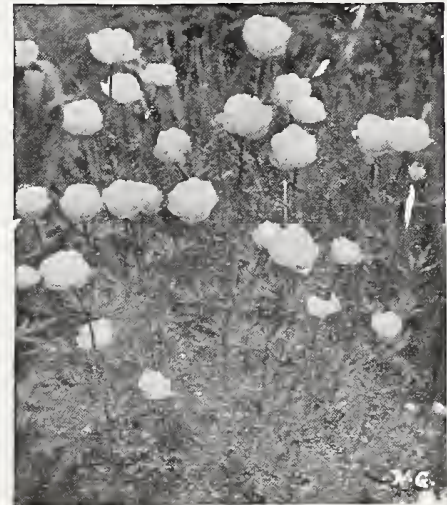

Trollius, Orange Globe. 


\section{Herbaceous and Alpine Plants}

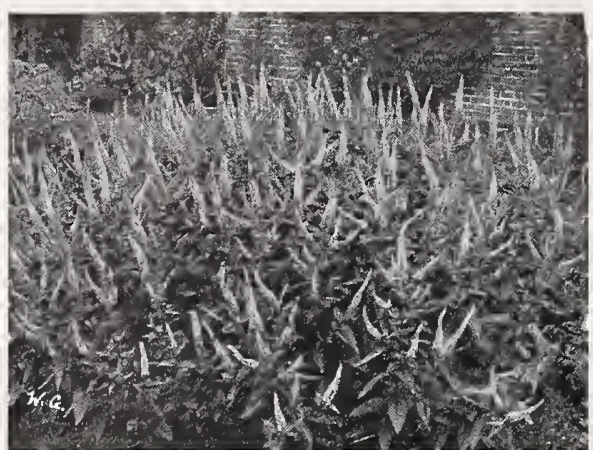

Veronica Amethystina.

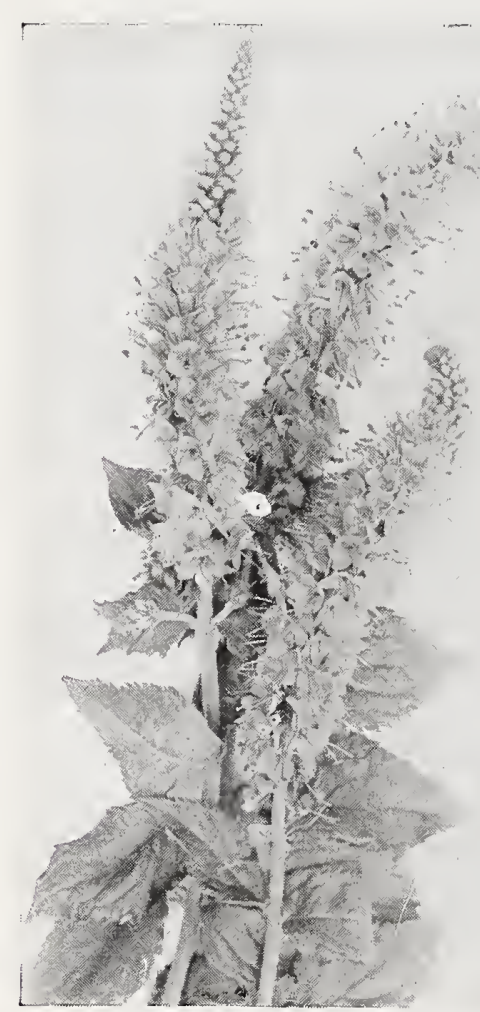

Veronica Longifolia Subsessilis.

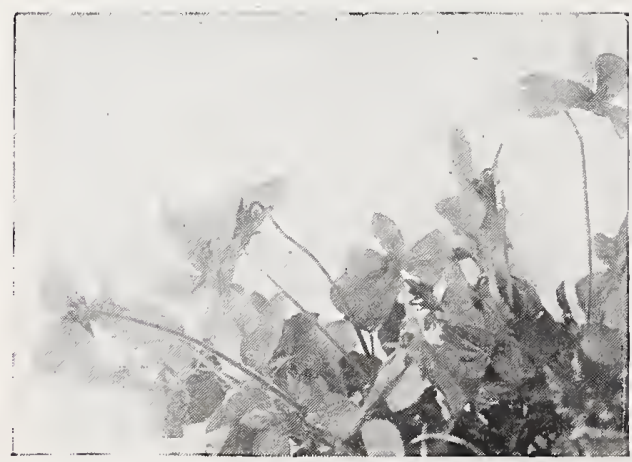

Viola, G. Wermig.
VERONICA (Speedwell).

A family containing some of the most beautiful subjects for the hardy garden and rockery. Given a rich, wels thrive in an amazing manner.

THREE CHOICE VERONICAS FOR SPRING, 1926.

Three Doz. 100

Amethystina "Royal Blue." Beauti-

ful spikes of rich Gentian-blue
flowers. 1 foot. June and July. $\$ 1.20 \quad \$ 3.50 \quad \$ 25.00$

Rupestris Trehani. A fine dwarf trailing variety with clear blue

flowers $\ldots \ldots \ldots \ldots \ldots \ldots \ldots$.................

True Blue. Literally covers itself with blossoms of intense blue. 1 foot. (Sold out for this season).

THE FOILOWING ARY OBTAINABIE THIS FAII.

Amethystina. 8 to 12 inches. June. A slender species, with short spikes of amethyst-blue flowers.

Incana. 1 foot. July and August A white, woolly plant; flowers numerous; blue. Has good ap pearance, both in and out of bloom.

Iongifolia subsessilis. 2 feet. July to September. One of the handsomest blue-flowering plants. Perfectly hardy and increases in strength and beauty each year. Spikes completely studded with beautiful blue flowers; fine for cutting and one of the best plants cutting and one of the best plants

for the hardy border ...........
Repeng. 3 to 4 inches. May and June. A useful rock or carpeting plant with light blue flowers ...

Rupestris. A fine rock plant growing 3 to 4 inches high; thickly matted, deep green foliage, hidden in Spring under a cloud of bright blue flowers $\ldots \ldots \ldots \ldots \ldots \ldots \ldots$

Spicata. 18 inches. June and July. Long spikes of violet-blue flowers. spicata alba. Long spikes of snowy picata alba. Long spikes of snowy

spicata rosea. 2 feet. June to tember. Much-branched variety with pink flowers $\ldots \ldots \ldots \ldots$.

Virginica (Great Virginian Speed-
well). A free-growing perennial well). A free-growing perennia Flowers white or pale blue. 2 to 6 feet August to September .... $1.00 \quad 3.00 \quad 20.00$

VERBASCUM (Mullein)

Olympicum (Greek Mullein). The showiest of the entire family of more than thirty varieties. The foliage is silvery white, with leaves often 3 feet long. The flowers are yellow, and are produced in quantity for about three weeks in midsummer. Succeeds best in a dry situation. 3 to 5 feet $\ldots \ldots \ldots \ldots \ldots \ldots \ldots \ldots$

Wayside Gardens Mybrids. An excellent strain produced from a very
superior grade of English Hybrids superior grade of English Hybrids
Colors are most interesting ....

OLA (Tufted Pansy).

This is the best edging plant for the hardy border or garden; when properly cared for, these plants remain in full bloom from May until October. The great secret of their continuous bloom though is the fact that they must be sheared several times during the season, so that the flowers do not go to seed.

\section{CORNUTA HYBRIDS.}

Jersey Gem (New). Possesses the Three Doz. 100 dwarf habit and continuity of blooming of the true horned Viola (V. cornuta), and the vigorous, bushy growth and roundish folibushy growth and roundish foliage of the finest English bedding varieties. Color is pure, rich vio-
let and slightly perfumed. (Sold let, and slightly perfur

G. Wermig. A variety of Tufted Pansy, forming clumps which are covered with rich, violet-blue flowers the entire season ...... $1.00 \quad 3.00$ 


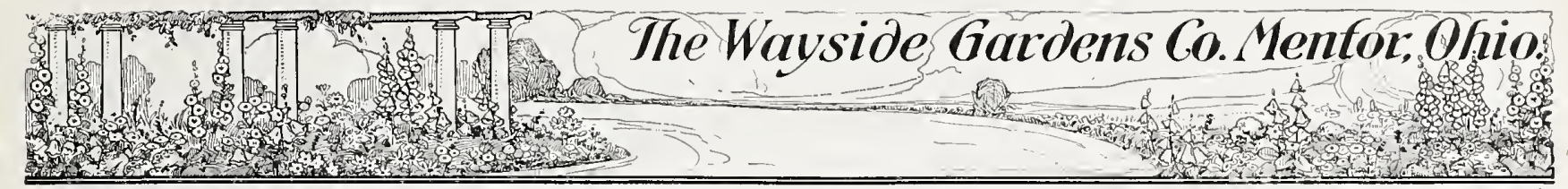

\section{VIOLA CORNUTA-Continued.}

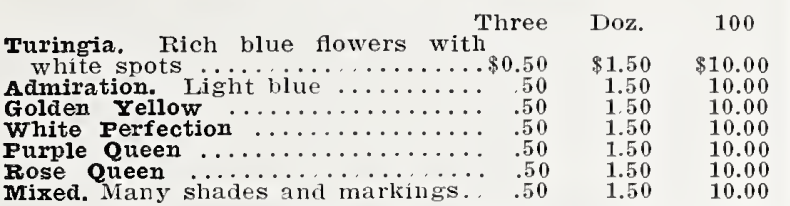

\section{VIOLA ODORATA (Sweet Violet).}

The variety listed below is suited for forcing under glass: and perfectly hardy, and is covered with flowers in early Spring and wonderfully sweet scented.

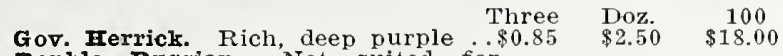
Double Iussiar. Not suited for forcing under glass, but is perfectly hardy, producing in early Spring large, double, deep purple flowers of exquisite fragrance (Sold out for this season).

VINCA (Periwinkle or Trailing Myrtle).

Minor. A trailing, evergreen plant, used extensively for carpeting the ground under shrubs or trees or on graves, where it is too shady

on graves, where it is too shady
for grass or other rlants to thrive.

\section{WALLFLOWER.}

The old fragrant favorite; mixed colors; choice English imported strain including yellow, brown. $\begin{array}{lllll}\text { etc. Plant in Spring only } & \cdots & 85 & 2.50 & 18.00\end{array}$

\section{WULFENIA.}

Carinthiaca. A rare plant for the rock garden. Glossy, deep green leaves and handsome spikes of rich blue flowers. 9 to 12 inches.

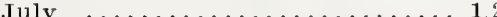

YUCCA (Adam's Needle).

rilamentosa. Among hardy plants there is nothing more effective and striking for isolated position on the lawn or on dry banks where few other plants thrive. It is also indispensable for the rockery. Its broad, swordlike, evergreen foliage and immense branching spikes of drooping, creamy white flowers, rising to a height of 6 feet, render it a bold and handsome subject wherever placed. some subject wherever placed. 3-year.old plants ............. 1.00 3-year-old plants $\ldots \ldots \ldots \ldots \ldots \ldots \ldots$
4-year-old plants $\ldots \ldots \ldots \ldots \ldots$

3.00 4.50

20.00
35.00

\section{CLIMBING PLANTS AND VINES} AMPELOPSIS (Ivy).

Veitchi (Boston Ivy or Japan Ivy) The most popular climbing plant for covering brick walls, stone or wooden walls, trees, etc. When it becomes established it is of very rapid growth, and clings to the smoothest surface with the tenacity of Ivy. The foliage is of a rich olive-green during the Summer, changing to various shades of bright crimson and scarlet in the Fall In planting Ampelopsis of all kinds, the plants, if still in a dormant condition, should be cut down to within 6 inches of the ground, so that the new growth may cling to the wall or tree from

Extra strong, 2-year-old plants ...\$0.50

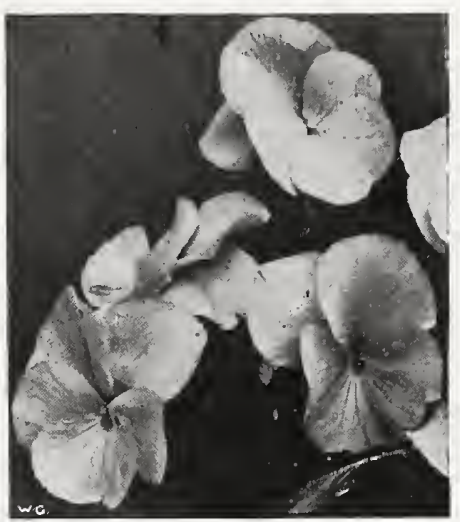

Viola Cornuta.

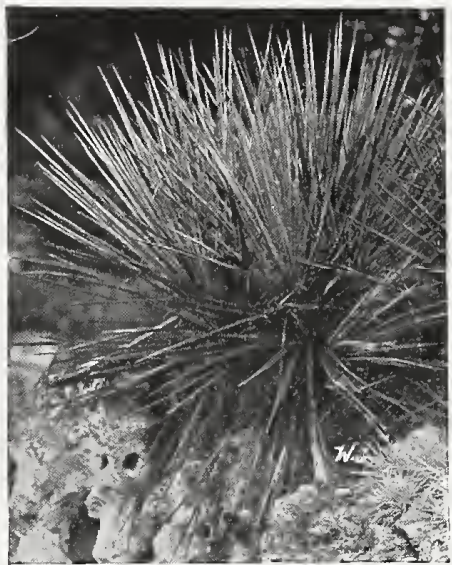

Yucca Filamentosa.

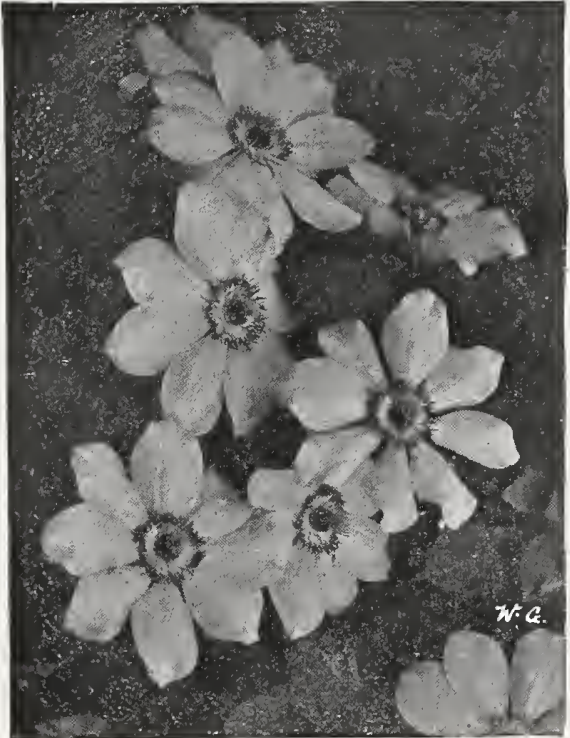

Clematis Jackmani. 


\section{Terbaceous and Alpine Plants}

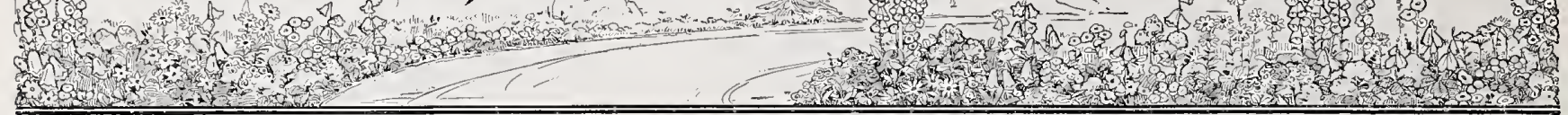

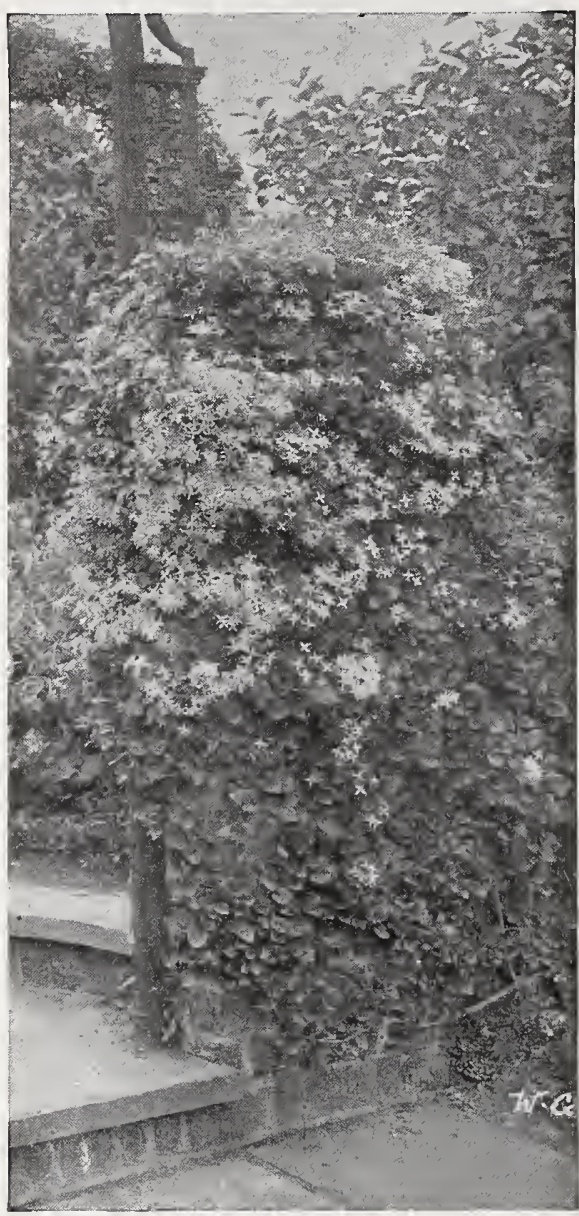

Clematis Paniculata.

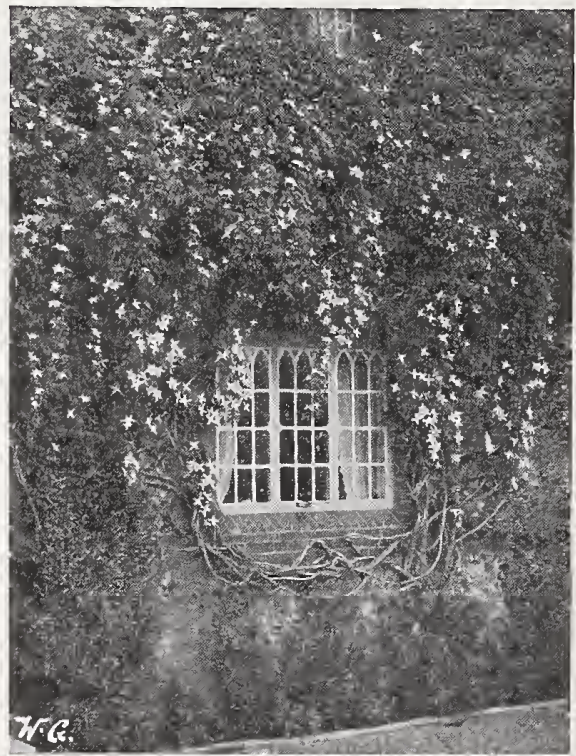

Clematis Montana.
ARISTOLOCHIA (Dutchman's Pipe).

sipho. A vigorous and rapid-growEach Doz. 100 ing climber, bearing singular brownish colored flowers, resembling in shape a pipe. Its flowers, pared to its light green leaves, which are of very large size, and retain their color from early retain their color from early hardy strong plants.......... \$1.25 $\$ 12.00$

BIGNONIA (Trumpet Vine).

For covering unsightly places, stumps, rock work, or wherever a showy flowering vine is desired, the Bignonias will be found very useful. The flowers are large, attractive, and borne profusely when the plants attain a fair size.

Radicans. Dark red, orange thach Doz 100 free blooming and very hardy $\ldots \$ 0.40 \quad \$ 4.00 \quad \$ 30.00$

CALYSTEGIA (California Rose).

Fubescens (The Double Japanese

Convolvulus). A vigorous climbing vine with attractive, double pink flowers. (Sold out for this season).

CLEMATIS (Virgin's Bower).

Faniculata (Japanese Virgin's Bower). This handsome hardy climber is one of the choicest and most satisfactory climbing flowering plants. Of strong, rapid growth, with small, dense, cheerful green foliage, and pure white, deliciously fragrant flowers, which appear in the greatest profusion in August and September followed by silvery feathery seed pods, which make an attractive appearance until midwinter.

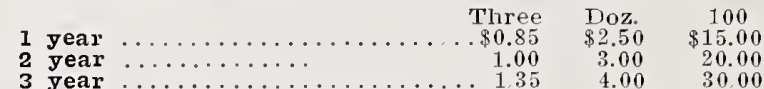

rlammula. Very beautiful climber;

white flowers: wants a sunuy ex- 1.70

posure ....................... $1.70 \quad 4.00 \quad 30.00$

Jackmani. Beautiful, large, deep $3.00 \quad 11.00$

Montana Ferfecta (Anemone Clemtremely A strong, vigorous, exunder most adverse conditions. Its large, white flowers expand in April and May, and it is the best of our Spring climbers .........

Montana rubens. Flowers rosy-pink, with beautif ul siower roliage, shaded bronze ................ $1.70 \quad 4.00 \quad 30.00$

Orientalis (Tangutica or Grav"olens. This is the beautiful rich yellow flowers in midsummer: a vigorous, free-flowering and hardy vine, often flowering again in Autumn ................ $1.00 \quad 3.00 \quad 20.00$

EUONYMUS (Evergreen Bittersweet).

The trailing Euonymus are particularly desirable for their dense, evergreen foliage and extreme hardiness, sorne varieties on account of this taking the place of the English Ivy for wal covering, others that of the boxand one of the best creepers for rockeries.

Three Doz. 100 Radicans. Deep green foliage, use-
ful for covering low foundation walls, or may be clipped the same as boxwood for an edging plant..\$1.70 $\$ 5.00 \quad \$ 40.00$ Radicans variegata. A beautiful small-leaved, green and white variegated form of the same habit as the type ............................. sweet). A strong growing variety, with larger leaves than the type. and producing bright orange-red berries, which remain on the berries, which remain on the plant the greater part of the Win-
ter. As an evergreen, absolutely ter. As an evergreen, absolutely hardy wall cover, this plant is ticultural writer predicts that it will become as popular for this purpose here as the Ivy is in England. Extra strong ............ $1.70 \quad 5.00 \quad 40.00$ 


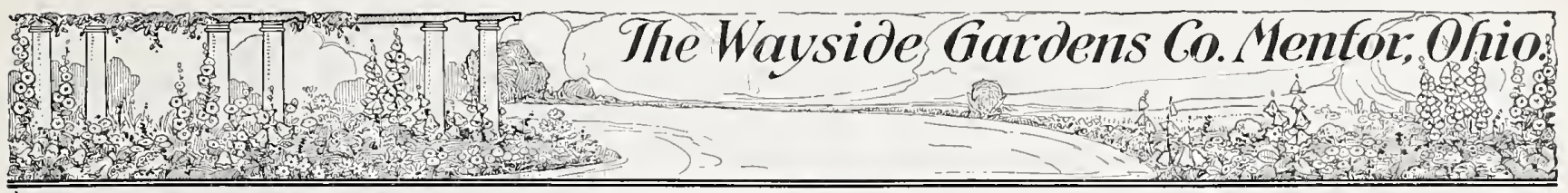

HEDERA (Ivy).

The famous English Ivy with its familiar evergreen, glossy foliage is unforturately not very hardy in this climate, and requires Winter protection where it is explanted with perfect safety as a ground cover or as an edging to flower beds.

Helix (English Ivy). 4-inch pots. Three $\begin{array}{rlr} & \text { Doz. } & 100 \\ \$ 1.70 & \$ 5.00 & \$ 40.00\end{array}$

LONICERA (Honeysuckle).

Their vining qualities are all that can be desired, but the fragrance of their flowers makes their strongest bid for favor.

Halieana. Color an intermingling of white and yellow. Extremely

fragrant and most satisfactory $\ldots \$ 1.20 \quad \$ 3.50 \quad \$ 25.00$

POLYGONUM (Silver Lace Vine).

Auberti. A splendid hardy elimber of strong, vigorous growth, attaining height of 25 or more feet, producing during summer and Fa!l great foamy sprays of white flowers, and a well established plant during its long period of flowering is a great mass of bloom. Not only does it thrive well in the eastern and middle states, but we have seen it in cquelly good weondition in Oregon, Colorydo and California, adapting itself to the most varia, allinatie

conditions .................... $1.70 \quad 5.00 \quad 40.00$

PUERARIA (Kudzu Vine).

The most rapid growing vine in cultivation, often attaining a growth of 40 feet in a single season. Especially desirable for immediate effect for dense shade, as its leaves are large.

Thunbergiana (Jack-and-the-Bean-

Three Doz. 100

Stalk), Small, pea-shaped, rosy

purple flowers, heart-shaped

Field-grown plants

\section{WISTERIA.}

Woody vines with tightly clinging habit, for pergolas, arbors, trellises, etc., especially ornamental in early summer when they are resplendent with their large, drooping clusters of fragrant blossoms. es of pale lilac, deliciously scented blossoms in great profusion all over the vine Strong

plants ..................... \$1.70 $\$ 5.00 \quad \$ 40.00$

Sinensis alba

form of the tyope strong plants. 1.70 $5.00 \quad 40.00$

\section{HARDY SHRUBS}

Varieties Used With Herbaceous Plants in Hardy Plant Borders and Rock Gardens

BUDDLEIA (Summer Lilac).

Variabilis magnifica (Butterfl Three Doz. 100 Bush). This is properly a shrub. but the top usually freezes back and new growth starts from the root like other perennials. Plants grow three to four feet and are covered with long racemes of lilaclike flowers in July. The best like flowers in July. The best location is in good, rich, well $\$ 1.50 \quad \$ 5.00 \quad \$ 45.00$

CARYOPTERIS (Blue Spirea)

Mastacanthus. A handsome hardy perennial; grows about 3 feet high and produces rich lavender-blue lowers in great profusion the whole length of the branches. A valuable plant either for bedding or pot culture, blooming continuously from early in September

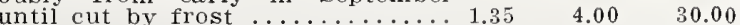

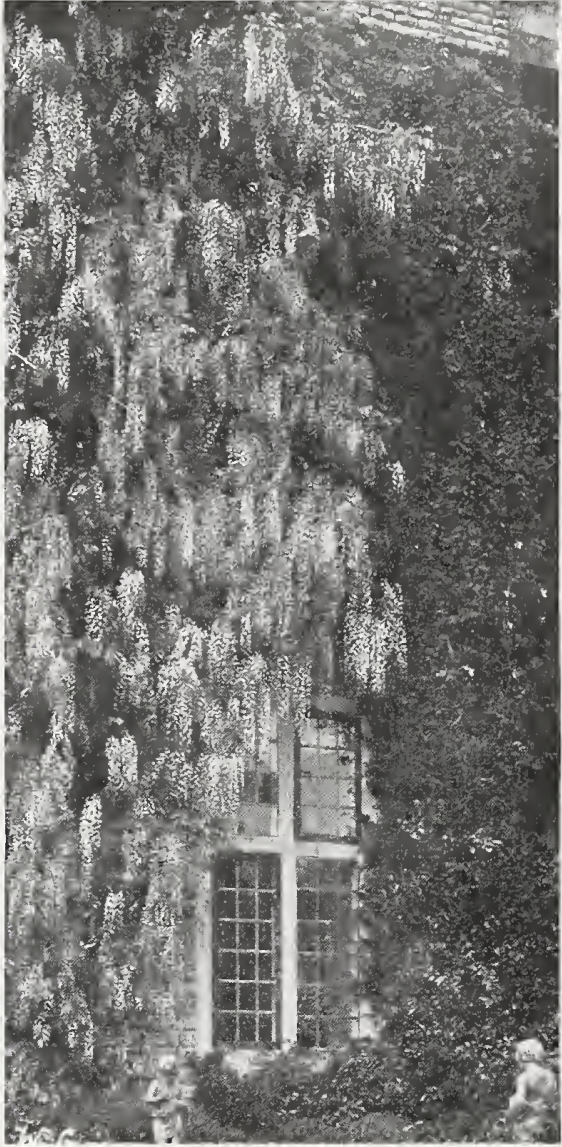

Wisteria Sinensis.

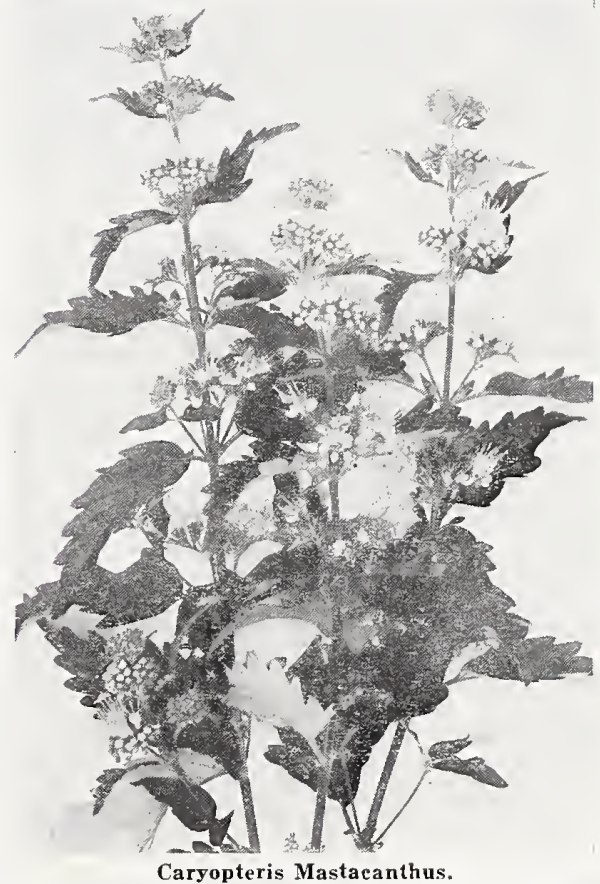




\section{Herbaceous and Alpine Plants}

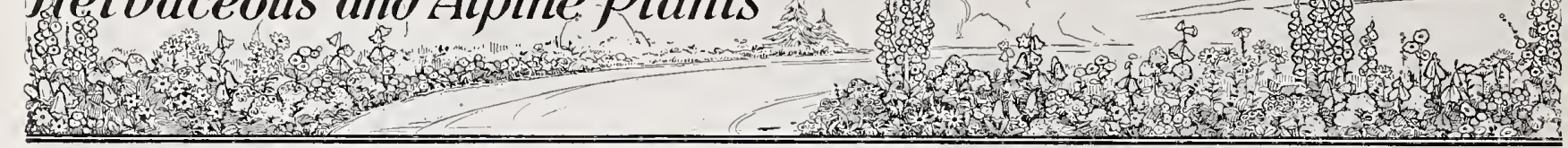

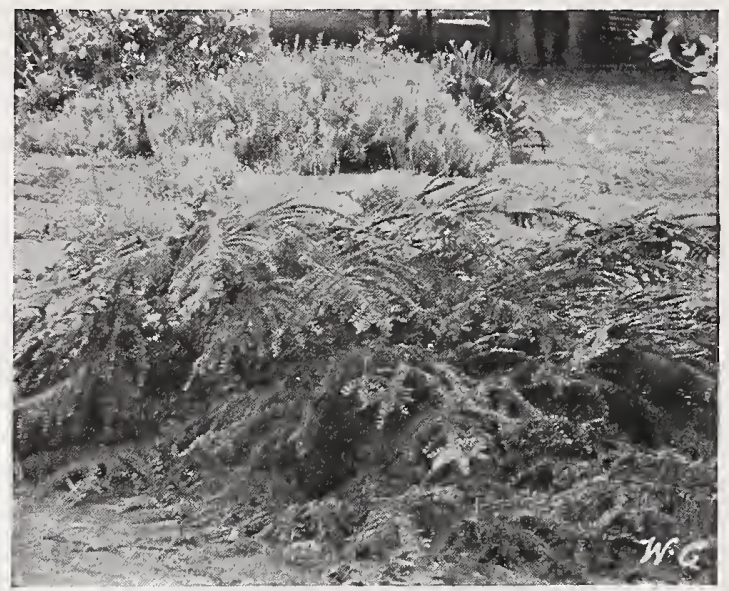

Cotoneaster Horizontalis.

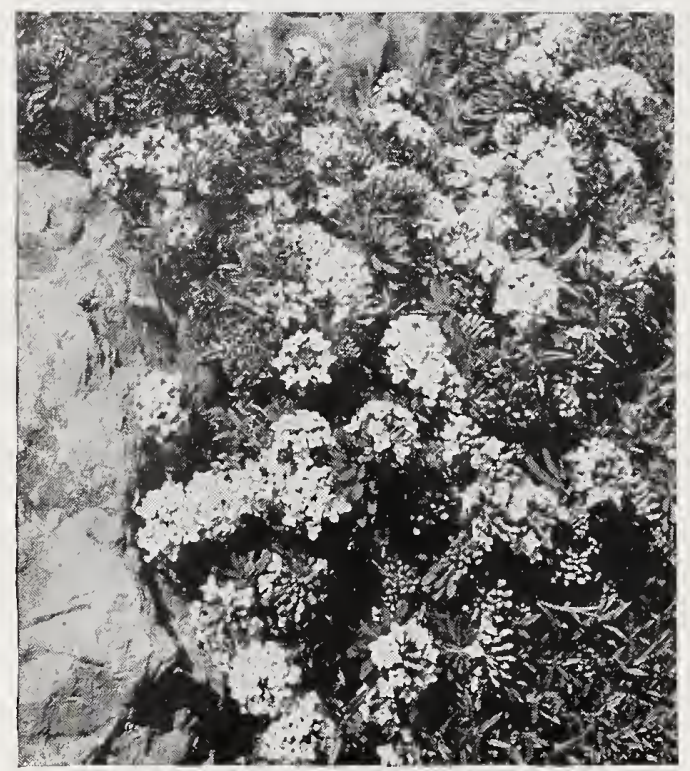

Daphne Cneorusn.

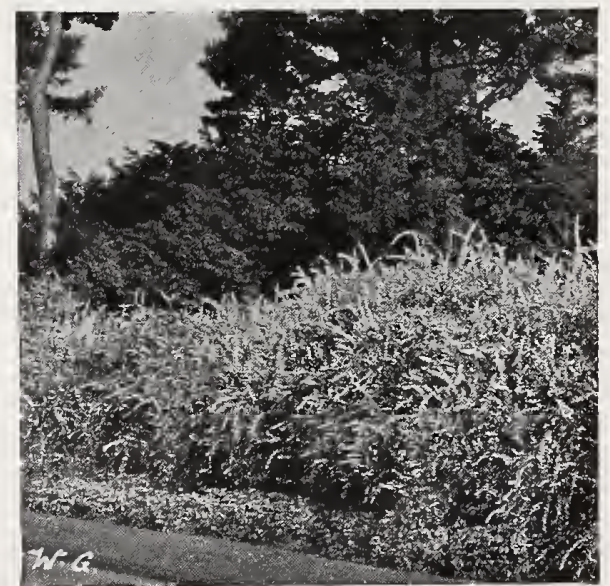

Barberry Hedge.
mARDY SARUBS -Continued.

COTONEASTER (Rock Spray). Each Doz.

100

Forizontalis (Prostrate Cotoneaster)

A low shrub with almost horizon-

Leaves dark green, about half an

inch long; flowers pinkish white;

fruit bright red; attractive in

rockeries. A most desirable ground

cover, and should be largely

planted Cannot be transplanted

unless from pots.

$\$ 0.75 \$ 7.50$

DAPHNE (Garland Flower).

Cneorum. Handsome dwarf subshrubs, mostly evergreen; excellently suited for planting near the front of shrubberies, with odorous, pink flowers and hand-

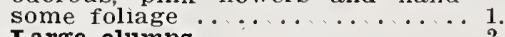

Iarge clumps ..........

Penduliflorum. An exceedingly graceful shrublike plant covered with purplish red flowers in summer time when little else is in bloom Strikingly beautiful................

HYPERICUM (St. John's Wort).

Ienryi. The same as Moserianum, though slightly more upright in growth and much hardier and bet -

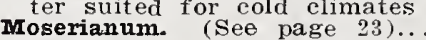

VITEX (Chaste-tree; Hemp-tree).

Macrophylla. In general habit similar to V. Agnus Castus, but much stronger in all its parts, the foliage being larger while the trusses of lavender-blue flowers are fully double the size It blooms from July to September, and is likely to become as popular as the sider it far superior .......... $1.00 \quad 10.00 \quad 90.00$

\section{DWARF SHRUBS AND EVERGREENS \\ (For Rock and Alpine Gardens).}

ANDROMEDA (Lily-of-the-Valley Shrub).

Catesbaei (Leucothoe). A valuable plant with oblong shiny foliage dark green in Summer, turning to a bronzy red in the Fall. The fragrant white flowers are boine in pendulous racemes. Adapted flowers are bolne in pendulous racemes. Adapted

AZALEA (Pinxter Flower; Swamp Honeysuckle).

Amoena (Japanese Evergreen Azalea). A dwarf shrub with double purplish red flowers in May. is especially adapted for borders and rock gardens; needs some protection in northern latitudes. Should be planted in sheltered positions and will abundantly repay for any care given it . ....... Mollis (Japanese Azalea). Of dwarf habit; resembles rhododendron; good foliage; flowers in al shades of red, yellow and orange, perfectly hardy, for mass planting. It must not come in contact

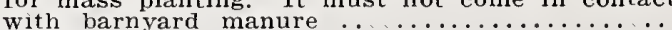

BUDDLEIA (Summer Lilac)

Farquhari (New). A low-growing pendulous, spreading shrub, with rich green foliage and silvery reverse, bearing in late Summer long racemes of purple flowers

\section{HEDGE PLANTS}

\section{BERBERIS (Barberry)}

Doz. 100

1000

Thunbergi (Japan Barberry). Wher awarf deciduous hedge is wanted, nothing equals this beautiful Barberry. Requires but little pruning to keep in shape. The leaves are small, light green, and towards Fall assume rich, brilliant colors, the fruit or berries becoming scarlet. Absolutely hardy. Plant 12 to 15 inches apart. Extra strong, 3-year-old plants. 12 to 18 inches high ...

SPIREA (Meadow grandest of all the Spireas, and one of the very best of all shrubs. A complete fountain of pure white A complete fountain of pure white 


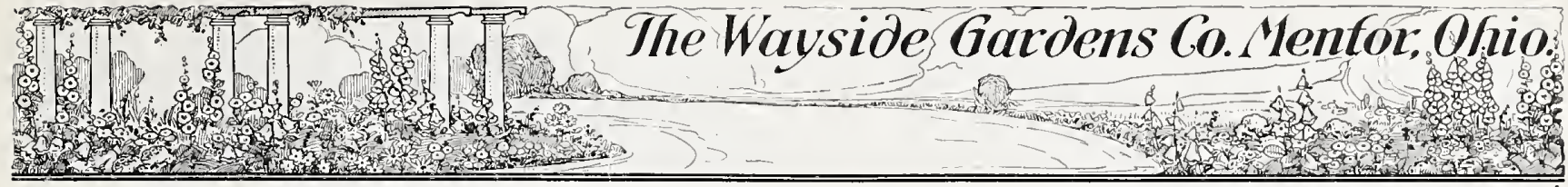

\section{BULBS FOR FALL PLANTING}

In order to complete our service in furnishing hardy material for gardens, we are herewith offering an excellent selection of Imported Dutch Bulbs. Varieties most suitable for forcing are indicated by a star (*). We are doing this upon request of our customers who have ween most insistent in their demand that we furnish them with bulbs of the same high quality as the plants we send out. We are able to give this service due to the fact that our secretary and treasurer, Mr. J. J. Grullemans is a son of the owner of the firm of J. J. Grullemans \& Sons, Iisse, Holland, who are the second largest bulb growers in the world.

\section{DARWIN TULIPS}

The figure following the name indicates the relative time of flowering:

Baronne de la Tonnaye. 4. Bright rose, margined blush rose. Height 26 inches .......\$0.55 $\$ 4.50$

*Bartigon. A very showy, shapely flower of good substance on strong stem; fiery crimson with pure white base, broadly ringed deep blue. It is splendid for forcing. 28 inches. 1.15

9.00

*Bleu Aimable. 4. Pale lavender, with white base, starred blue; beautiful flower of dis tinet stared biue; beautifue

1.2510 .00

clara Butt. 4. Clear pink, flushed salmonrose; inside much deeper, with blue base. beautiful out-of-doors. Height 21 inches..

*Crepuscule. 3. Lilac-white, with dark rosy flush at tips of petals; large flower. Height

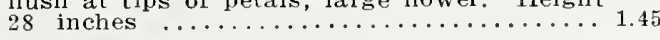

*Dal Ongaro. 4. Pale lavender-violet; inside dark bluish violet with pure white base Height 28 inches

Dream. 2. Pale heliotrope, inside deep violet with blue base. Ifeight 27 inches ........

* Europe. 2. Salmon-scarlet, shaded rose with white base; medium sized flower on strong stem. Height 22 inches

* Euterpe. 2. Silvery mauve-lilac, edged paler liiac white base with blue halo a lons flower of exquisite color. Height 28 inches.

* Faust. 2. Darls purple-maroon with blue base very large flower. Height 30 inches

Feu Brilliant. 2. The most glorious scarlet Tulip ever raised, large and beautifully shaped flower on strong stem: one of the first to bloom. Height 28 inches ........ 1.00

*Flamingo. 4. Soft shell-pink; medium sized flowers of refined form. Height 28 inches.

* Ia Candeur; syn., White Queen. 2. Almost white when mature; with black anthers; me-

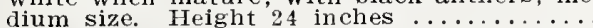

*Ia Tulipe Noire. 3. Dark maroon-black, the blackest of all the Tulips. Large flower. Height 25 inches

*Madame Krelage. 2. Bright lilac-rose, margined pale silvery rose; inside soft rose pink; long flower. Height 28 inches .....

*Margaret; syn., Gretchen. 3. Silvery pale rose, flushed white, inside soft pink with white base marked blue. Height 22 inches.

*Massachusetts. 2. Vivid pink, edged rosy whitc, white base. Large flower of beautifu color. Height 26 inches

*Mr. Farncombe Sanders. 2. Scarlet; inside vivid cerise-scarlet with white base; large. Flower of perfect shape. One of the best among the reds. Height 25 inches ........

Pride of Haarlem. 1. Brilliant rosy carmine with blue base; very large flower on tall strong stems; sweet scented. Unsurpasse for borders. Height 25 inches

Painted Iady. 3, Creamy white, tinged soft heliotrope. Height 27 inches

*Princess Elizabeth. 2. Clear deep pink, changing with age to rose-pink, white base. Liarge flower. Height 26 inches............ $75 \quad 4.50$ $45 \quad 12.00$
* Professor Rauwenhof. 3. Bright cherry-red ${ }^{10}$ Enormous flower. Height 28 inches .....\$1.05 \$ 8.00

*Reverend Ewbank. 2. Soft lavender-violet with silvery gray flush, white base; good sized flower of beautiful color. Height 22 inches

*Sophrosyne, 2. Soft rosy lilac, edged silvery

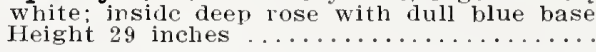

viola. 2. Dark violet; strong, large flower

Fine Mixture of Darwins. As imported. Not $55-5.00$

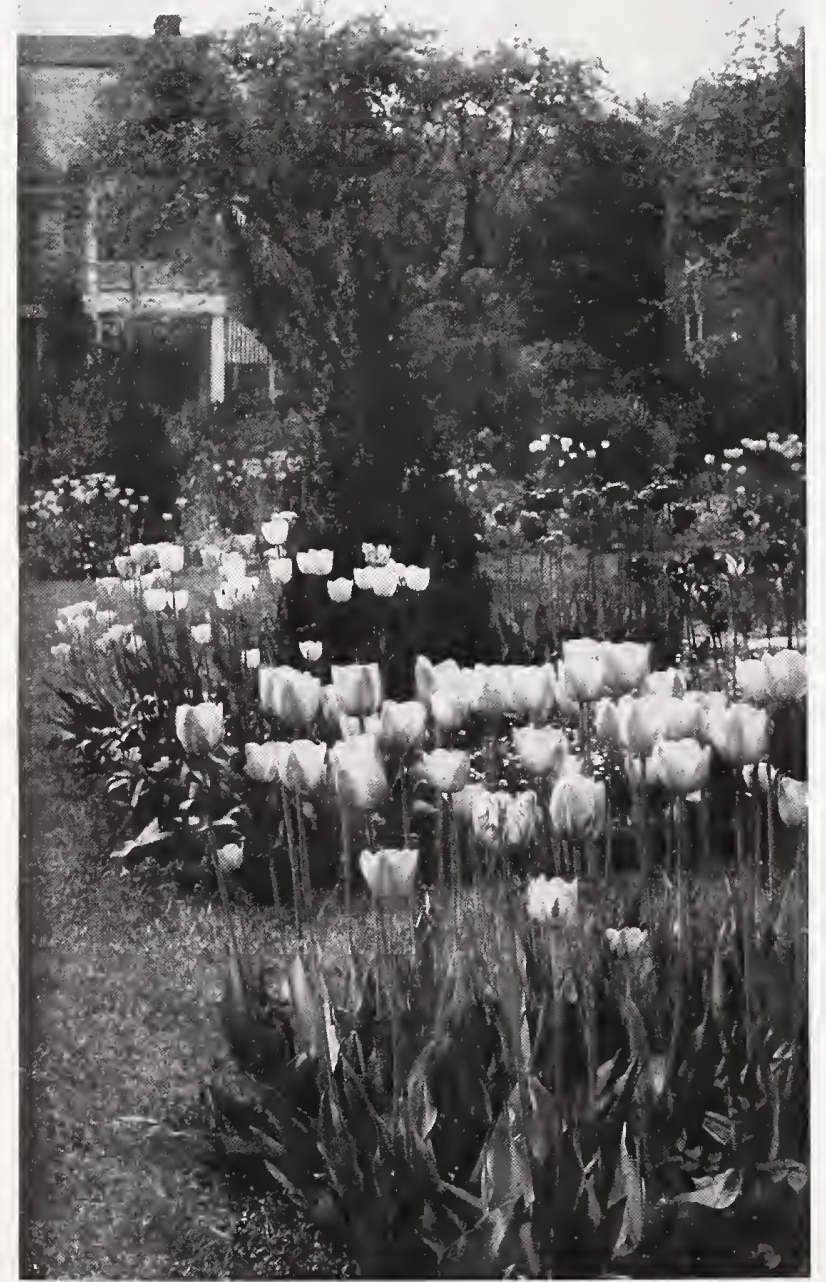




\section{MAMMOTH BREEDER TULIPS}

Apricot. Dull, bronzy buff, shaded ruddy 10 apricot above base ...............\$1.00 Bronze Queen. Soft buff, inside tinged

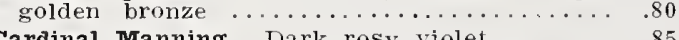

Cardinal Manning. Dark rosy violet ...... .85

Dom Pedro. Coffee brown-maroon, shaded... 1.45 Godet Parfait. Bright violet; striking color extra lal'ge flower's which keep wonderfully. 1.40

Golden Bronze. Rich golden brown ......... 1.00

Iouise XIV. Rich dark purple, shaded steelblue, heavily flushed bronze, edged golden brown; enormous size and stately bearing . 2.00

Mon Tresor. 3. Indian red, with orange tone at edge of petals; inside dull blood-red, with yellow base marked bronze; a medium sized flower; quite distinct. Height 25 inches .. 1.00

Fanorama or Fairy. Deep orange-red, shaded mahogany immense flower ............. 1.00 Prince of Orange. Orange-red, lighter border. 1.10 Turenne. Dark blue, heavily flushed bronze at margin; very large flower bud ....... 1.00

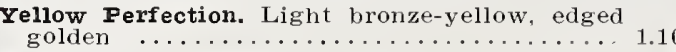

Finest Irixed Colors

\section{PARROT OR DRAGON TULIPS}

Finest Mixed Parrots

\section{COTTAGE OR MAY-FLOWERING TULIPS}

Bouton a'Or. Deep golden yellow; of great 1 value for cutting ................\$0.55 \$ 4.50

Ellen willmott. One of the finest May-flowering Tulips. Flowers very large, beautifully shaped, soft creamy yellow, deliciously fragran

Inglescombe Pink. Salmon-pink, blue base; very brilliant

Inglescombe Yellow. Glossy canary-yellow The large, globular flower has the true shape of the Darwin Tulip, hence is called

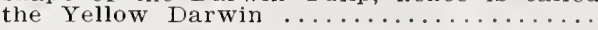

John Ruskin. Salmon-rose, edged lemon-yellow; inside deep rosy lilac, with malgin of
yellow; large flower of fine shape. Height 16 inches

Moonlight. New. Light, soft yellow

Mrs. Moon. Pure yellow, large. The best of all yellow late Tulips

Parisian Yellow. Golden yellow. pointed ...

Picotee or Maiden's Blush. Long, elear white; the petals, which are pointed and elegantly reflexed, are beautifully margined and penciled on edges with bright pink

The Fawn. Large; light gravish rose, changing to rosy white Distinct

special Mixture of Iate Single TuIips

\section{DOUBLE EARLY TULIPS}

*Boule de Neige (Purity). 10-M. Pure white, large, peony-like flower; is a splendid forcer and bedder ..................................... Golden yellow flushed Couronne d'or. 11-M. Golden yellow flushed
orange; a magnificent flower of great beauty and size; stiong stems, holding flower upright; fine forcer

IMr. Van Der Hoef. A yellow sport of Murillo with all its superb qualities. One of the very finest of the primrose-yellow, double Tulips. A very lovely flower. Height 13 inche ine Murillo. Delicate blush pink. A very fine llower with a lovely color. An old variety

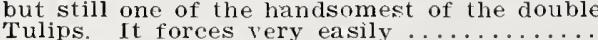

vuurbaak. 12-M Bright scarlet; splendid bedder; large, well shaped flowers on strong stems

Superb Double Mixture. Our own special mixture which we recommend for best results in beds of mixed colors. This mixture is named varieties

\section{0}

8.00

6.00

6.00

12.00

12.00

9.00

18.00

7.50

7.50

8.00

8.00

8.00

6.00

00

4.50

14.00

4.50

\section{is}
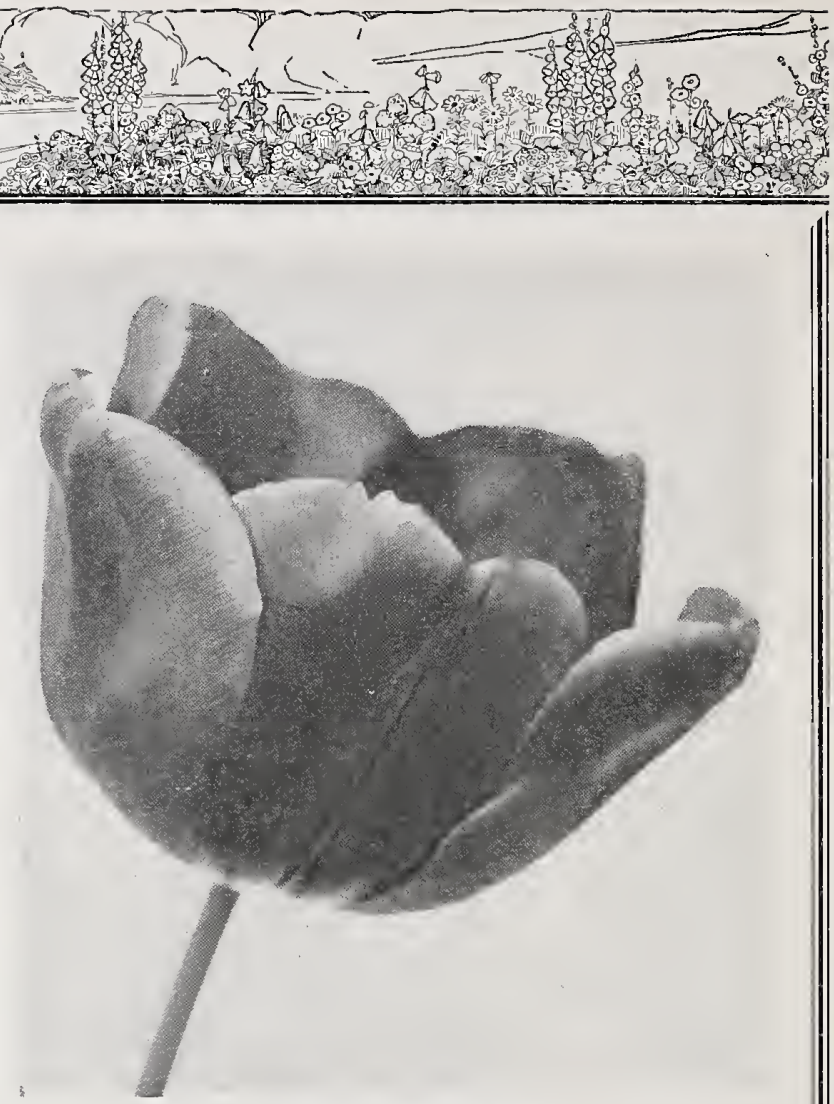

Breeder Tuilp, Apricot.

\section{CHOICE SINGLE EARLY TULIPS}

Couleur Cardinal. 12-D. Outside bronzescarlet, inside glittering crimson; large, fine

flowers. Fine for bedding and late forcing $\ldots \$ 1.00 \$ 7.75$

Flamingo. 12-C. White, flaked bright carminerose. A sport from White Hawk, having its artistic shape with its more or less crinkled

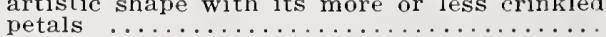

*Goldfinch, 10-B. The true Yellow Prince. Golden yellow: sweet scented; forces easily and early, lasts long when cut; retains color.

*Joost Van Vondel (White Lady Boreel). 12-B. The largest and most intense of the white early Tulips. Splendid forcer and

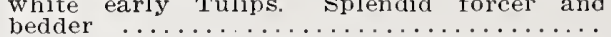

* Keizerskroon (Grand Duc). 14-B. Carminescarlet with broad yellow border. This old variety, which forces well, remains a great favorite for bedding; should be planted by itself

Ie Reve; syn., American Iac; Hobbema; Sarah Bermhardt. 4. Old rose; very large flower on a strong stem. Beautiful when grown out-of-doors. Fine for late forcing. Height

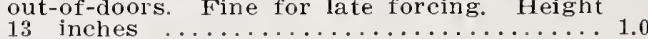

13 inches $\ldots \ldots \ldots \ldots \ldots \ldots \ldots \ldots \ldots \ldots \ldots \ldots \ldots \ldots \ldots$.

fine, large flower. One of the hest and

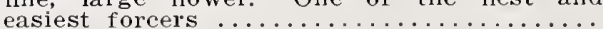

Rising sun. 2. Very deep golden yellow; long, huge flower of very handsome form and huge flower of very handsome form and which excels all yellow Tulips for bedding or forcing. Height $\mathbf{1 6}$ inches ............... 1.00

* Rose Iuisante. 10-C. Dark silky rose; the finest rose variety. Both a forcer and bedder. 1.00

*Vermilion Brilliant. 10-B. Bright vermilion; best of its class. Forces very readily; fine

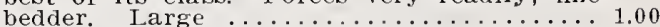

White Beauty. This is a pule white sport of Pink Beauty and it is destined to become quite as popular as its parent. Flowers large, of fine substance and purest white..

superb single Mixed. This is our own special mixture which we recommend where the best results are desired in beds of mixed colors. This mixture is made up of the colors. This mixture is made up of the

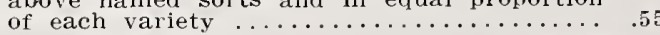




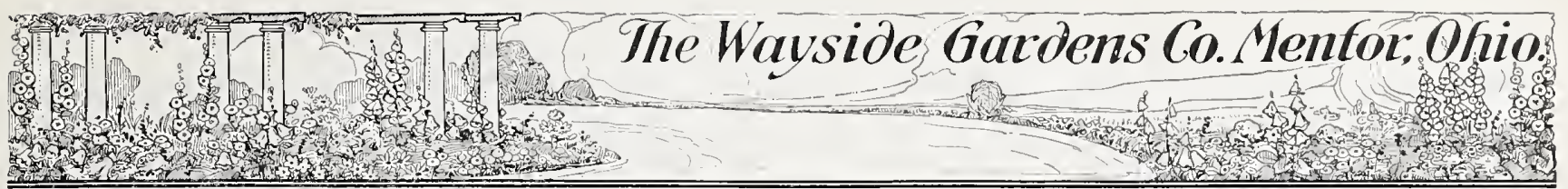

\section{GIANT TRUMPET DAFFODILS YELLOW TRUMPET DAFFODILS}

Emperor. Large, rich yellow trumpet; primIor cutting. Mammoth bulbs $\ldots \ldots \ldots \ldots \ldots \ldots \ldots \ldots \ldots \ldots \ldots \ldots \ldots \ldots \ldots \ldots \ldots$. $\ldots \ldots$. soft yellow; of largest size and always sat isfactory. Mammoth bulbs

Golden spur. Native of the Netherlands Large lobed trumpets, rich, deep self-yel low; perianth large and spreading; early. Mammoth bulbs

King Alfred. Uniform golden yellow; this variety stands unrivaled in size and beauty. Its round, fleshy petals, its immense, elepet and its sturdy growth proclaim it the King of Daffodils. Mammoth bulbs ......2.25

\section{BICOLOR TRUMPET DAFFODILS}

Empress. Very large and beautiful white perianth; rich yellow trumpet. Mammoth

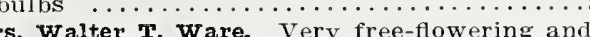

Mrs. Walter T. Ware. Very free-flowering and expanded and frilled at the base ..........

victoria. Large, erect flowers; creamy white perianth and rich yellow trumpet; forces easily. The earliest of the Bi-colors. Mam-

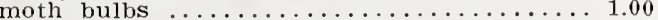

\section{WHITE TRUMPET DAFFODILS}

Madame de Graaff. Perianth white; trumpet 10 pale primrose, passing off white .......\$1.25

\section{THE SHORT TRUMPET OR CROWN DAFFODILS}

\section{NARCISSUS INCOMPARABILIS}

Iucifer. Large, sulphur-white, loosely formed perianth; cup chrome-yellow, edged bright orange-red . .................................. Largest of the Incomparabilis varieties; fine for forcing; cup yellow; perianth primiose.

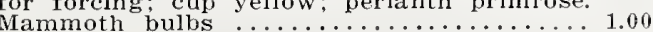

\section{NARCISSUS BARRI}

Conspicuus. Large, spreading yellow perianth; fine scarlet cup; strong grower, fine blooming and durable cut flower variety ...

Firebrand. Creamy white perianth, intense fiery red cup: very distinct ..........

\section{NARCISSUS LEEDSI}

Mrs. rangtry. White perianth and white cup; largely used for forcing; free bloomer ....\$0.60 \$5.00 white Iady. Broad white perianth; dainty unaded soft lemon. Beautifully crinkled. A very pretty flower ................... 1.10

\section{DOUBLE-FLOWERED DAFFODILS}

Alba plena odorata. Double, pure white; sweet ccented and fine for naturalizing, especially in shady, moist locations .........\$0.60 Orange Phoeniz or Eggs and Bacon. Sulphuryellow, crimson center

The Double von Sion or Golden Yellow Daffodil. Fine for the garden and is forced in great quantities for cut flowers. Mammoth bulbs.

\section{POET'S NARCISSI}

Glory of Iisse. An improved form of Poeticus Ornatus; extra large flower; late forcer...
rnatus. rnatus. Early; pure white cup, margined
scarlet; forces very easily. Double-crown bulbs

\section{POETAZ HYBRID DAFFODILS}

Elvira. Pure white, with yellow cup; most $10 \quad 100$ popular rlondyke. Yellow, with golden yellow eye ... 1.009 .00

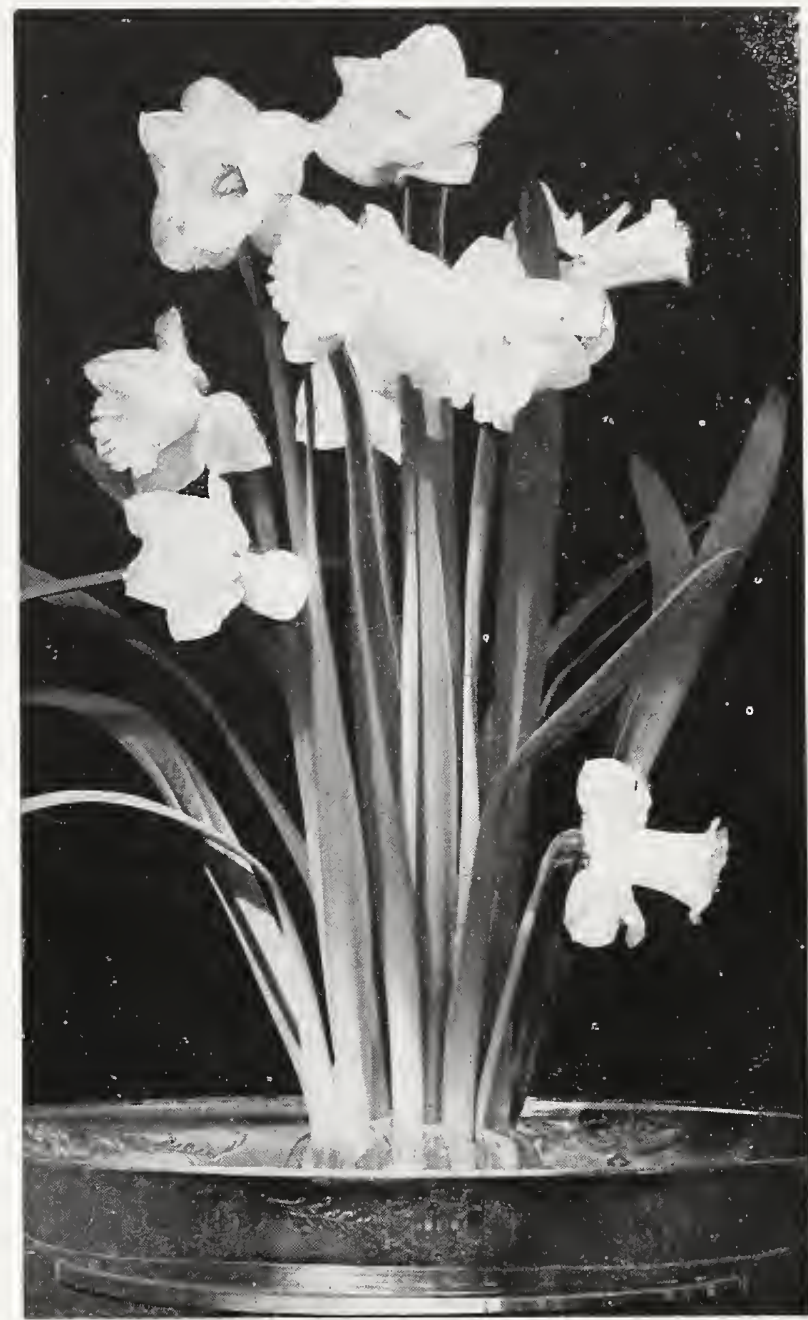

Narcissus, Emperor.

NARCISSUS ODORUS (JONQUILS)

Campernelle rugulosus. Large, rich yellow flowers, borne very freely, and fine for cut-

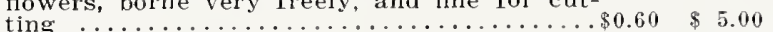

\section{PAPER-WHITE GRANDIFLORA}

First Size Selected Bulbs Extra Iarge Mammoth Bulbs $\begin{array}{rr}10 & 100 \\ \$ 0.70 & \$ 5.00 \\ .75 & 5.50\end{array}$

\section{NARCISSI FOR NATURALIZING}

Naturalizing Daffodils, meaning planting them scattered irregularly in quantity, is a rare pleasure. They "bring sunshine into shady places", wooded bank or open meadow, covered with these golden flowers is a charming sight, as is a grove of white birches carpeted with them. A fairly good rule to follow is, the paler the Daffodil the more it enjoys the shade.

All varieties mixed, $\$ 40.00$ per case of thousand extra heavy bulbs.

$\$ 375.00$ per ten thousand bulbs.

Not less than 250 bulbs sold for $\$ 10.00 ; 500$ at $\$ 20.00$. Ali charges included except expressage from Mentor. Guaranteed to bloom profusely. 


\section{Terbaceous and Alpine Plants}

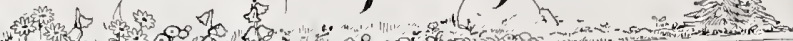

\section{HYACINTHS}

First size bulbs as listed below, $\$ 2.50$ per 10; $\$ 20.00$ per 100.

\section{BIUSF WHTTE}

General Vetter. White, shaded blush, changing to pure white when in full bloom. Strong grower with large, well filled spikes.

\section{IIGHT ROSE AND PINK}

General De wet. Lively light pink with a lighter center large trusses with good sized bells. Fine for forcing or bedding.

Iady Derby. Beautiful, clear rose-pink, with large, compact trusses. Farly and fine for forcing and bedding.

\section{IIGHT BIUE AND IIIAC}

Perle Brilliant. Light blue, tinged lavender; splendid spikes with large, substantial bells. A fine pot Hyacinth and good for bedding.

Queen of the Blues. Clear light porcelain-blue; a strong growing variety with large, well formed trusses. One of the best of its color, particularly for bedding.

\section{PURE WHITE}

Ia Grandesse. Pure white with fine, compact spikes The best late forcing variety; fine for bedding as well. Innocence. This is the most satisfactory all-around pure white. Compact spikes with large bells. Does well indoors and out.

\section{RFD AND DFFP ROSF}

Gertrude. Deep rose-pink; compact spikes on good stems. A very popular forcing variety; also used for bedding. spikes. A splendid bedding variety.

\section{BIUE AND DARK BIUE}

Grand Maitre. Deep blue with long, compact spikes of large bells, on strong stems. One of the most popular blues; fine for pots as well as bedding.

King of the Blues. Dark violet-blue; splendid, large trusses. One of the best known blue Hyacinths. Good for late forcing and bedding.

\section{YHILOW AND ORANGE}

City of Haarlem. The finest of the yellows. Well formed trusses of orange-yellow bells. An excellent variety for forcing and bedding.

\section{FEATHER AND GRAPE HYACINTHS}

These will grow in any good garden soil, and are excellent for borders that are shaded by trees. They should be planted in large elumps, and be allowed to remain several years undisturbed. They are also well adapted for pot culture and for rockwork.

The Grape Hyacinth is a most interesting flower, perfectly hardy, robust in habit, and admirably suited for the adornment of vases, for which purpose clumps should be planted in the reserve border.

\section{FEATHER FYACINTHS - Muscari Plumosus}

Plumosus. Pretty pale mauve $\ldots \ldots \ldots \ldots \ldots+\$ 2.50 \quad \$ 4.50$

GRAPE HYACINTIS - Muscari Botryoides

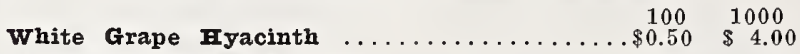
Iight Blue Grape Fracinth $\ldots \ldots \ldots \ldots \ldots \ldots \ldots . .30 \quad 2.75$

Heavenly Blue. Immense heads of rich bright
blue flowers. Excellent for cutting ...... .40

\section{ROMAN HYACINTHS}

Splendid for early forcing. Can be had in bloom in December.

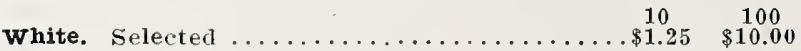

ERANTHIS HYEMALIS (Winter Aconite).

A very hardy, bulbous plant with beauti$10 \quad 100$ ful, bright yellow flowers, produced in early Spring on stems about 6 inches high. Excellent for naturalizing in half-shady positions

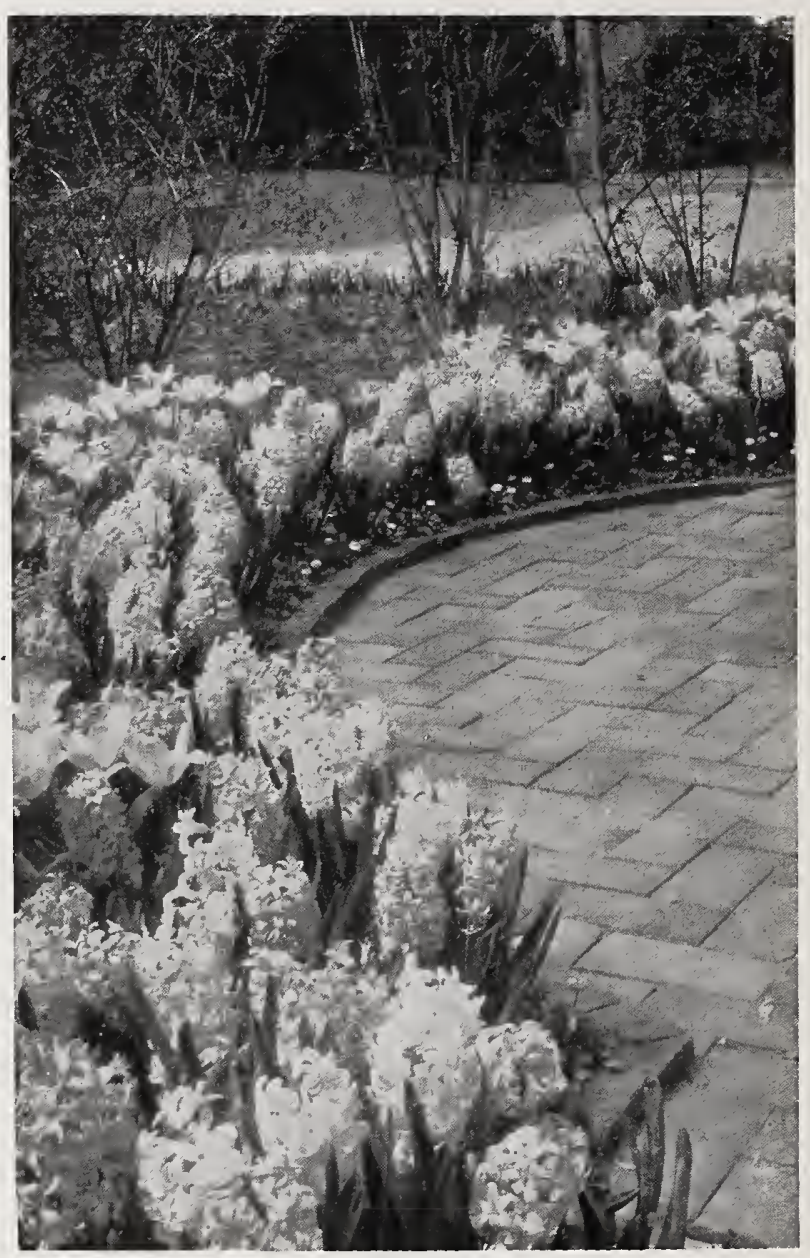

First Size Hyacinths.

CHIONODOXA (Glory-of-the-Snow).

A hardy early-flowering. bulbous plant which is closely allied to the Scilla, but differs among other characteristics in having a short tube to the corolla. A good companion to the Scilla and Snowdrop.

Luciliae. Pure white center gradually merg$10 \quad 100$ ing into blue, the color becoming more intense towards the tips of the petals. A flower; it also shows to great advantage in pots

Sardensis. Charming flowers of a rich gentian-blue. First class certificate, R. H. S... $\quad .40 \quad 3.00$

IXIA (African Corn Lily).

These charming, half-hardy bulbs from the Cape of Good Hope are very ornamental for indoor culture, or planted in cold frames or outdoors in well drained and protected borders. The flowers are of the most brilliant, rich and varied hues.

Fine Mixture. All colors $\stackrel{10}{\$ 0.50} \quad \stackrel{100}{\$ 4.00}$

\section{CROCUS-NEW LARGE-FLOWERING}

$\begin{array}{rrr}10 & 100\end{array}$

King of the Whites. Large purple, white edge. $\$ 0.25 \$ 2.00$ Marimilian. Pale blue ................ $35 \quad 3.00$ Mont Blanc. Pure white $\ldots \ldots \ldots \ldots \ldots \ldots \ldots \ldots . .25 \quad 2.00$ Mammoth Yellow .................. $5.50 \quad 3.00$

Sir Walter scott. White, striped lilac ...... $25 \quad 2.00$ Purpurea grandifiora. Purple ........... . $35 \quad 3.00$ 


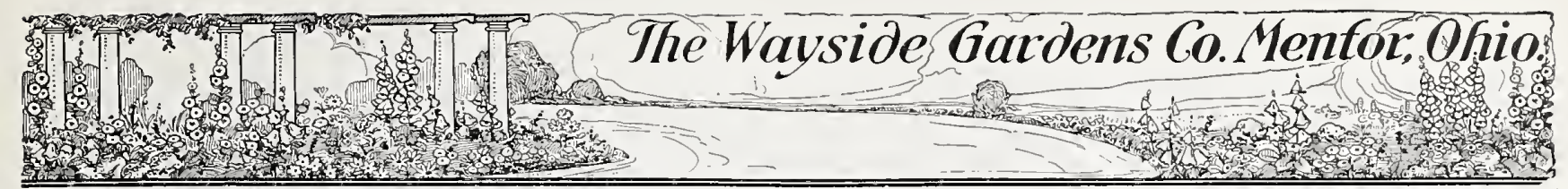

\section{SCILLA (Squill; Harebell).}

All the varieties of Scilla Campanulata and the Nutans family are splendid for naturalizing because they will flower in shady places. Both have bells like small hyacinths, forming long and graceful spikes. The Scilla Sibirica is used as a companion to Crocus, for borders or massing.

Campanulata alba maxima. Large, pure white. $\$ 0.50 \$ 3.00$ Campanulata, Frcelsior. Large, bright blue .. $\quad .50 \quad 4.00$ Campanulata, Rosy Queen. Soft lilac-rose . . $.60 \quad 5.00$ Nutans. These are larger than Campanurata. Nutans alba major. White ...............50 Nutans, Blush Queen. Delicate lilac-rose ... .60 Nutans coerulea (Bluebell). Violet-blue .... .50 Sibirica, Blue. Invaluable for indoor decoration. The lovely ultramarine-blue flowers contrast admirably with Roman Hyacinths Squill is perfectly hardy and should be largely grown in the open border in conjunction with Snowdrops. It is also valuable for small beds, and for making marginal lines in the geometric garden

Bifolia. Dwarf, rich blue flowers, which bloom with the Winter Aconite in March. Excellent for clumps, edgings, and rockwork

\section{FRITILLARIA}

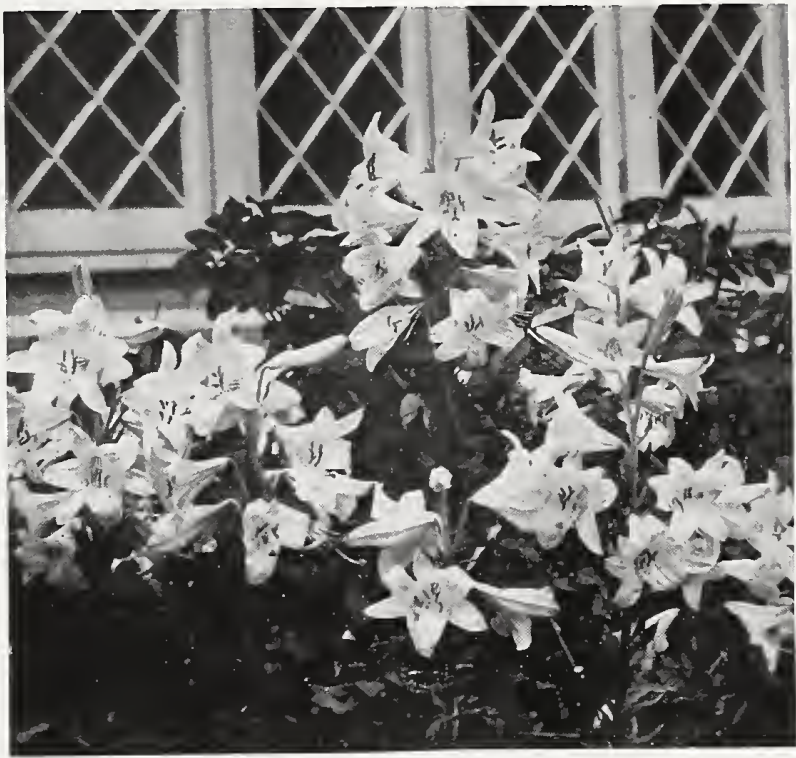

Liliua Candidum

\section{LILIUM CANDIDUM (Madonna Lily).}

Flower) (Snake's Head or Guinea Hen Flower). An elegant species, growing from ious drooping bell-shaped flowers, most of which are very oddly marked, many being checkered and splashed white and purple cream and maroon, etc. Perfectly hardy and selendid for naturalizing. Mixed colors $\ldots \ldots \ldots \ldots \ldots \ldots \ldots \ldots \ldots \ldots \ldots \ldots \ldots \ldots \$ \ldots 0 . \$ 4.50$

\section{FREESIA}

This is one of the most beautiful of all Cape bulbs, possessing a peculiar grace of form, and its fragrance is possessing a peculiar grace of form, and its fragrance is to perfume a whole house. As cut flowers, they are extremely valuable.

Purity. A magnificent, snowy white, of very

$0 \quad 100$

large size and great length of stem. A

truss bearing from 8 to 10 buds, of which

six are often open at one time. Mammoth

bulbs ................................ \$ $\$ 5.00$

\section{SNOWDROPS}

One of the earliest flowers of Spring. They can be planted in borders or lawns. Flowers white.

Single

$10 \quad 100$
Choice Northern Grown. Arrive in August or September. Choice Northern Grown. Arrive in August or September. trong, stiff stems, studded with pure, glistening white strong, stiff stems, studded with pure, glistening white thowers, that enliven the perennial fower garden and contrast beautifully with the green
quently growing $4 \frac{1}{2}$ feet high.

Plant some bulbs during September and October and enjoy a big crop of flowers next June; or put up, store in cold frame, and force for early Winter in the greenhouse or conservatory. Our bulbs of this splendid Lily are grown in Northern France, and are of the true, thickpetaled variety, which is much superior in habit and flowering qualities to that of the cheap, loose, southern grown bulbs. Our stock from the north of France is hardy and will live in your garden indefinitely.

Selected Bulbs Mammoth Bulbs

$2.50 \$ 20.00$

Our bulbs of this splendid white Lily are the finest that come to America and are much larger than those usually sent out. We supply the best bulbs only, from Northern France.

\section{Planting Table for Plants and Bulbs}

PIANTING. The table below shows the number of plants or bulbs required to fill a circular bed of the dimensions given. In planting begin at outside row-where 6 inches apart, 3 inches from edge of bed: wherc 12 inches apart, 6 inches from edge of bed. It is customary among professionals in planting a bed to set the plants or bulbs somewhat closer together in the two outer rows, giving more space between each plant or bulb toward the center of the bed.

\begin{tabular}{|c|c|c|c|c|c|c|c|c|c|c|c|}
\hline $\begin{array}{c}\text { Diameter of } \\
\text { bed }\end{array}$ & $\begin{array}{l}6 \text { in. } \\
\text { a part }\end{array}$ & $\begin{array}{l}12 \text { in. } \\
\text { apart }\end{array}$ & $\begin{array}{l}18 \text { in. } \\
\text { a part }\end{array}$ & $\begin{array}{l}24 \text { in. } \\
\text { apart }\end{array}$ & $\begin{array}{l}30 \text { in. } \\
\text { apart }\end{array}$ & $\begin{array}{c}\text { Diameter of } \\
\text { bed }\end{array}$ & $\begin{array}{l}6 \mathrm{in} . \\
\text { apart }\end{array}$ & $\begin{array}{l}12 \mathrm{in} . \\
\text { apart }\end{array}$ & $\begin{array}{l}18 \text { in. } \\
\text { apart }\end{array}$ & $\begin{array}{l}24 \text { in. } \\
\text { apart }\end{array}$ & $\begin{array}{l}30 \text { in } \\
\text { a part }\end{array}$ \\
\hline $\begin{array}{rc}3 & \text { feet } \\
4 & \text { “ } \\
5 & \text { “ } \\
6 & \text { “. } \\
7 & \text {. } \\
8 & \text {. } \\
9 & \text {. } \\
10 & \text {. }\end{array}$ & $\begin{array}{r}28 \\
48 \\
80 \\
112 \\
152 \\
200 \\
256 \\
320 \\
380\end{array}$ & $\begin{array}{r}7 \\
12 \\
20 \\
28 \\
38 \\
50 \\
64 \\
80 \\
95\end{array}$ & $\begin{array}{r}6 \\
8 \\
13 \\
17 \\
23 \\
28 \\
36 \\
42\end{array}$ & $\begin{array}{r}7 \\
9 \\
12 \\
16 \\
20 \\
24\end{array}$ & $\begin{array}{l}13 \\
16\end{array}$ & 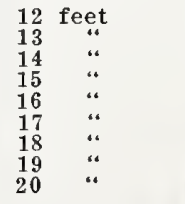 & $\begin{array}{r}\mathbf{4 5 2} \\
\mathbf{5 2 8} \\
\mathbf{6 1 2} \\
704 \\
\mathbf{8 0 4} \\
904 \\
1016 \\
1132 \\
\mathbf{1 2 5 6}\end{array}$ & $\begin{array}{l}113 \\
132 \\
153 \\
176 \\
201 \\
226 \\
254 \\
283 \\
314\end{array}$ & $\begin{array}{r}50 \\
59 \\
68 \\
78 \\
89 \\
100 \\
113 \\
126 \\
139\end{array}$ & $\begin{array}{l}28 \\
33 \\
39 \\
44 \\
50 \\
57 \\
63 \\
71 \\
78\end{array}$ & $\begin{array}{l}18 \\
22 \\
25 \\
28 \\
32 \\
36 \\
4.7 \\
46 \\
50\end{array}$ \\
\hline
\end{tabular}

A square bed will take about the same number of plants. For an oval bed, add length and breadth and divide by two. For example, an oval 9 feet long by 7 feet wide will require same number of plants as circular bed 8 feet in diameter. 


\section{Herbaceous and Alpine Plants}

\section{H E R B S}

The plants offered below are all strong roots, and will make an abundant growth the first season.

Frice, except where noted, 25c each; $\$ 2.50$ per $12 ; \$ 18.00$ per 100 .

ASPARAGUS ROOTS, Colossal and Palmetto. 2-year, $\$ 1.50$ per 100; $\$ 10.00$ per 1000. 3-year, $\$ 2.50$ per $100 ; \$ 15.00$ per 1000 .

BAIM (Melissa officinalis). For culinary purposes.

CFAMOMIIE (Anthemis nobilis). Has medicinal qualities. CHIVES. For flavoring.

HOP ROOTs (Humulus lupulus).

FOREHOUND (Marruhium vulgare). Has medicinal qualities.

FORSERADISH ROOTS. Used for sauces. 50c per 10; $\$ 2.00$ per 100 .

myssop (Hyssopus officinalis). Has meāicinal qualities.
IAVENDER, True (Lavandula officinalis). For oil and distilled water.

MARJORAM, Pot (Origanum onites). Used in seasoning. RHUBARB ROOTS, Linnaeus and St. Martins.

ROSFMARY (Rosmarinus officinalis). Yields aromatic oil and water.

RUE (Ruta graveolens). Said to have medicinal qualities. SAGE, Common (Salvia officinalis). A culinary herb, also used in medicine.

SAVORY, winter (Satureia montana). Used as a culinary lierb

TANSY HERB (Tanacetum vulgare).

TrimE (Thymus vulgaris). Used in seasoning.

WOODRUFF (Asperula odorata). Used in flavoring wine. Wormwood (Artemisia absinthium). Has medicinal

\section{Special Announcement to Garden Clubs}

DURING the past summer we have secured about two hundred colored lantern slides of the most popular hardy perennials for both border and rock gardens. While this does not embrace every class offered in our catalog, yet we hope to add to the collection so that by next year we will have a complete collection of slides showing the plants under actual growing conditions in our nursery.

Further, we are prepared to make arrangements with Mr. Shipman, of Willoughby, Ohio, who is a very keen naturalist and a wonderful photographer to show his collections of colored slides of birds and bird life and also wild flowers. Incidentally, we are indebted to Mr. Shipman for helping us in tinting our slides.

Garden Clubs interested in having these very instructive colored slides shown should write us for further information and conditions under which they may be obtained.

\section{M P O R T A N T}

Last season we were very unfortunate in receiving seed of Sweet Williams which was not true to color. This we were not able to know until the plants bloomed.

If every customer who ordered Sweet Williams will let us know how many plants they bought from us which did not flower true to color, we will replace them without charge either this fall or in the spring of 1926. 


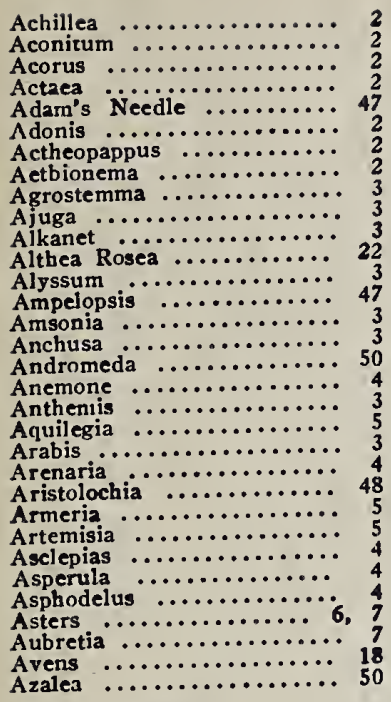

Baby's Breath ......... 19

Balloon Flower .......... 39

Baneberry $\ldots \ldots \ldots \ldots \ldots \ldots \ldots .{ }_{7}^{2}$

Baptisia.

Bearberry Tongue $\ldots \ldots \ldots \ldots \ldots . . \ldots \ldots$

Bellflower.$\ldots \ldots \ldots \ldots \ldots \ldots$ 9 7

Bellis $\ldots \ldots \ldots \ldots \ldots \ldots \ldots, 7_{50}^{7}$

Berbamot $\ldots \ldots \ldots \ldots \ldots \ldots \ldots \ldots .32$

Bergamot

Betony

Bignonia

Bishop's Cap.

Blanket Flower ......... 18

Blazing Star ........... 27

Bleeding Heart $\ldots \ldots \ldots \ldots \ldots \ldots, 14$
Bluebells $\ldots \ldots \ldots \ldots \ldots \ldots$

Blue-eyed Grass

Blue Gentian

Bocconia...$\ldots \ldots \ldots 8$, 49

Bocconia $\ldots \ldots \ldots \ldots \ldots \ldots \ldots \ldots$ \%

Rowman's Root ........... 18

Budale $. . . \ldots \ldots \ldots \ldots . . . .6$, 45

Bugleweed $\ldots \ldots \ldots \ldots \ldots \ldots$ s $^{2}{ }^{3}$

Buphthailmum $\ldots \ldots \ldots \ldots \ldots \ldots$. 8

Buttercups $\ldots \ldots \ldots \ldots \ldots \ldots .40$

Butterfiy Bush $\ldots \ldots \ldots \ldots \ldots 8$

Calamintha $\ldots \ldots \ldots \ldots \ldots \ldots .8 \%$

California kose $\ldots \ldots \ldots \ldots \ldots .48$

Callir.

Calystegia $\ldots \ldots \ldots \ldots \ldots \ldots$ 9, 48

Campanula Medium .......... 10

Campion..$\ldots \ldots \ldots \ldots \ldots .28$

Canterbury Bells ......... 10

Caryopteris $\ldots \ldots \ldots \ldots \ldots \ldots .4,49$

Cassia ................. 8

Catananche $_{\text {Catchfly }} \ldots \ldots \ldots \ldots \ldots \ldots \ldots \ldots .8 \%$

Cephalaria $\ldots \ldots \ldots \ldots \ldots \ldots \ldots$. 33

Centaurea $\ldots \ldots \ldots \ldots \ldots \ldots \ldots$ 2, 8

Cerastium

Ceratostigm

Cheiranthus $\ldots \ldots \ldots \ldots \ldots \ldots$ s0

Chelone

Chinese Lantern Plant ...... 39

Chrysanthemums .......... ii, 12

Chrysanthemum Maximum... 12

Cimicifuga ............. 10

Cinquefoil $\ldots \ldots \ldots \ldots \ldots \ldots \ldots \ldots$. 34

Clematis $\ldots \ldots \ldots \ldots \ldots \ldots 10,48$

Coneflower .......... 16,

Convallaria...$\ldots \ldots \ldots \ldots \ldots$..... 10

Cornflower Aster $\ldots \ldots \ldots \ldots$

Coronilla.$\ldots \ldots \ldots \ldots \ldots \ldots \ldots$
I N D E X

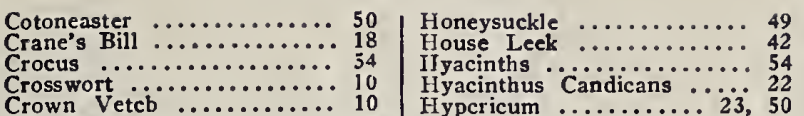

Iberis

Cup Flower

Cupid's Dart

Daffodils

Daphne ...............

Delpbinium $\ldots \ldots \ldots \ldots \ldots \ldots$ i4, 13

Desmodium $. . . \ldots \ldots \ldots \ldots 14,50$

Dianthus $\ldots \ldots \ldots \ldots \ldots 15,16$
Dianthus Barbatus ........ 16

Dictamnus $\ldots \ldots \ldots \ldots \ldots \ldots \ldots$ it

Dicentra
Dielytra $\ldots \ldots \ldots \ldots \ldots \ldots \ldots \ldots$
14

Digital is

Doronicum $\ldots \ldots \ldots \ldots \ldots \ldots .16$

Dracocephalurn $\ldots \ldots \ldots \ldots \ldots \ldots, 16$

Dutchman's I Pipe ........... 48

Echinacea $\ldots \ldots \ldots \ldots \ldots \ldots, 16$

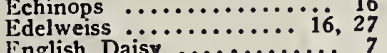

English Daisy $\ldots \ldots \ldots \ldots \ldots \ldots, 7$

Epilobium Eranthis Hyemalis ........... 54

Erianthus

Erigero

Eryngium

Erysimum

Eupatorium

Euphorbia $\ldots \ldots \ldots \ldots \ldots \ldots .{ }^{17}$

Everlasting Sweet $\mathrm{Pea} \ldots . .27$

False Chamomile

False Dragonhea

False Indigo

False Lupine

Ferns

Flame Flower.

Flax

Fleabane $\ldots \ldots \ldots \ldots \ldots \ldots, 16,23$

Freesia

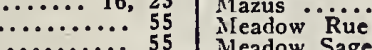

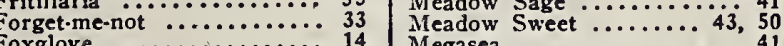

Funkia $\ldots \ldots \ldots \ldots \ldots, \ldots, 18$

Gaillardia

Garden Heliotrope

Garland Flower

Gas Plant

Gentiana

Geranium

Geum

Globe Flower

Globe Tbistle

Goat's Beard

Golden Drop

Grasses $\ldots$ La............

Great Sea Lavend Mallow

Ground Cypress

Groundsel

Hardheads

Hardy Ageratum

Hardy Candytuft

Hardy Gloxinia

Hardy Primrose

Hardy Zinnia

Harebell

Hawkweed

Hedge Mustard

Hedge Mustard

Helianthemum

Helianthus

Heliopsis

Hemp-tree

Hepatica

Hesperis

Hibiscus

Hieracium
Inula $\ldots \ldots \ldots \ldots \ldots \ldots \ldots \ldots \ldots{ }^{23}$

Ivy $\ldots \ldots \ldots \ldots \ldots \ldots \ldots \ldots \ldots, 23-27$

Jacob's Ladder .......... 40

King's Spear

Kuapweed

Lady's Slipper

Larkspur

Lavandula

Lavender $\quad \ldots \ldots \ldots \ldots \ldots \ldots, 27$

eontopodium

Leopardbane ............. 16

Lilies $\ldots \ldots \ldots \ldots \ldots \ldots 29.31$

Lily-of-thc-Valley $\ldots \ldots \ldots \ldots$ in

Lily-of-tbe-Valley sibrub.... 50

Linaria

Linuns Leaf

Lobelia

Loosestrife

Lupinus

Lycoris

Lysimacbia

Nallow

Marguerite

Matricari

Mertensi

Milfoil

Mitella

Miterwort

Monarda...

Monkshood

Montbretia

Mountain Feather Fleece

Mullein

Myosotis

Narciss

Nierembergia $\ldots \ldots \ldots \ldots \ldots \ldots, 33$

Onosma

Oswego Tea
Ox-eye Daisy

Pachysandra

Painted Daisy

Papaver Pavadicaule

Pardanthus

Pentstemon

Peonies

Persian Candytuf

Persian Daisy

Pheasant's Eye

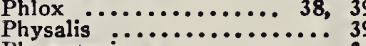

Pincushion Flower

Pinks

Pinxter Fiower

Plantain Lily

Platycodon

Plumbago Frass

Plume Poppy

Polygonatum
Indian Pink $\ldots \ldots \ldots \ldots \ldots \ldots .28$

Lavender Cotton

Nepeta .................

Oenother

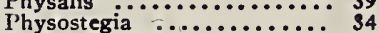

Polygonum ............ 49

Poppy Mallow............. 34

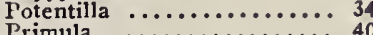

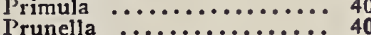

Pueraria $\ldots \ldots \ldots \ldots \ldots \ldots \ldots$ 40

Pyrethrum $\ldots \ldots \ldots \ldots \ldots \ldots . . .640$

Ranunculus ............. 40

Red Hot Poker ........... 45

Rock Cress $\ldots \ldots \ldots \ldots \ldots \ldots, 3,7$

Rock Madwort $\ldots \ldots \ldots \ldots \ldots, 2_{20}$

Rock Spray $\ldots \ldots \ldots \ldots \ldots \ldots \ldots, \ldots,{ }_{50}$

Rose Campion ............ 3

Rudbeckia $\ldots \ldots \ldots \ldots \ldots, 40,41$

Sage Brush ............ 5

Salvia $. \ldots \ldots \ldots \ldots \ldots \ldots, \ldots,{ }^{4}$

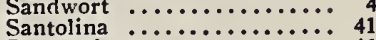

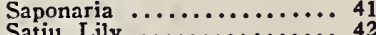

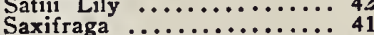

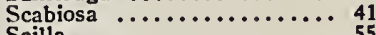

Scutellaria $\ldots \ldots \ldots \ldots \ldots \ldots \ldots, \ldots, 41$

Sea Holly........... .17

Sea Pink

Sedum

Sempervivum . .............4 42

Shasta Daisy ............... 12

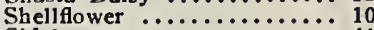

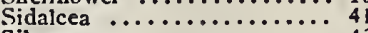

Silene $\ldots \ldots \ldots \ldots \ldots \ldots \ldots$ 42

Silver I,ace Vine $\ldots \ldots \ldots \ldots \ldots$
Sisyrinchiurn ${ }_{42}$

Skull Cap $\ldots \ldots \ldots \ldots \ldots \ldots \ldots, 41$

Snakeroot $\ldots \ldots \ldots \ldots \ldots \ldots \cdots \cdots \cdots$

Snow-in.Summer ............

Soapwort $\ldots \ldots \ldots \ldots \ldots \ldots .4{ }_{40}$

Speedwell $\ldots \ldots \ldots \ldots \ldots \ldots \ldots$ 46

Spiderwort .............. 44

Spirea $\ldots \ldots, \ldots, \ldots, \ldots, 43,50$

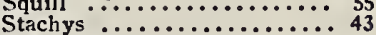

Statice Stenanthium $\ldots \ldots \ldots \ldots \ldots \ldots \ldots .6 \%$ 44 44

St. John's Wort $\ldots \ldots \ldots \ldots .23$; 50

Stokesia $\ldots \ldots \ldots \ldots \ldots \ldots \ldots$. 44

Stokes Aster $\ldots \ldots \ldots \ldots \ldots \ldots$
Stonecrop

Stonecrop ${ }_{\text {Silac }} \ldots \ldots \ldots \ldots \ldots . .6 \%$ 49

Sun Rose ................. 20

Swamp Honeysuckle ....... 5n

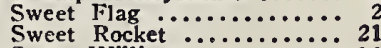

Sweet William $. . . \ldots \ldots \ldots \ldots . .16$

Thalictrum $\ldots \ldots \ldots \ldots \ldots \ldots$ 45

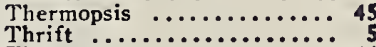

Thrymus $\ldots \ldots \ldots \ldots \ldots \ldots \ldots \ldots, 4_{44}^{5}$

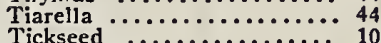

Tick Trefoil $\ldots \ldots \ldots \ldots \ldots \ldots \ldots, 14,50$

Toad Flax $\ldots \ldots \ldots \ldots \ldots \ldots \ldots, 28$

$\underset{\text { Tradescantia }}{\text { Torch Lily }} \ldots \ldots \ldots \ldots \ldots \ldots \ldots$. 44

Trailing Myrtie $\ldots \ldots \ldots \ldots \ldots$. 47

Trillium $\ldots \ldots \ldots \ldots \ldots \ldots \ldots, 3,44,45$

Trollius $\ldots \ldots \ldots \ldots \ldots \ldots \ldots .45$

Trumpet Vine $\ldots \ldots \ldots \ldots \ldots . \cdots, 48,48$

Tulips $. . . \ldots \ldots \ldots \ldots \ldots, 51,52$

Tunica

Valeriana $\ldots \ldots \ldots \ldots \ldots \ldots \ldots .45$

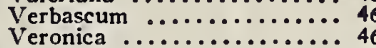

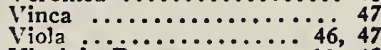

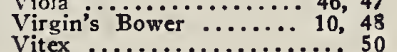

Wake Robin $\ldots \ldots \ldots \ldots \ldots, 44$

Wallfower $\ldots \ldots \ldots \ldots \ldots 10,47$

Willow Herb $\ldots \ldots \ldots \ldots \ldots \ldots$
W'ind flower
16

Winter Aconite $\ldots \ldots \ldots \ldots \ldots, 54$

Wisteria $\ldots \ldots \ldots \ldots \ldots \ldots \ldots, 49$

Wood Lily $\ldots \ldots \ldots \ldots \ldots \ldots \ldots, 44$

Woundwort $\ldots \ldots \ldots \ldots \ldots \ldots \ldots$
Wulfenia $\ldots \ldots \ldots \ldots \ldots$
43

Yarrow $\ldots . . .1 .1$
Yellow

Yucea 
